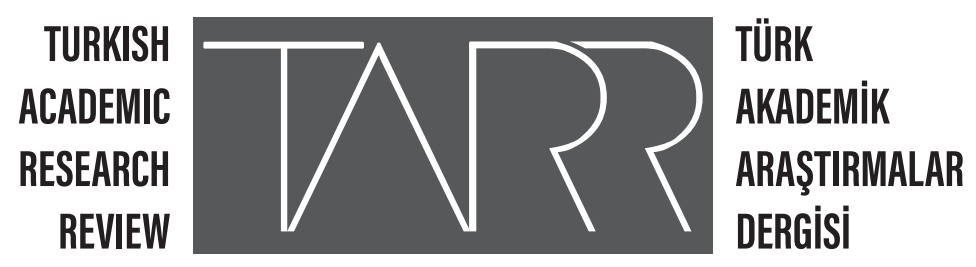

Antalya Selçuklu Kervansarayları

Seljuk Caravanserais in Antalya

\author{
Ali BAKKAL \\ Prof. Dr., Akdeniz Üniversitesi İlahiyat Fakültesi/ \\ Prof. Dr., Fakulty of Divinity Akdeniz University, Antalya / Turkey \\ alibakkal52@gmail.com \\ Orcid: 0000-0003-4948-2736 \\ Makale Bilgisi | Article Information \\ Makale Türü-Article Type | Araştırma Makalesi / Research Article \\ Geliş Tarihi-Date Received | 7 Kasım / November 2019 \\ Kabul Tarihi-Date Accepted | 25 Aralık/December 2019 \\ Yayın Tarihi-Date Published | 31 Aralık/ December 2019 \\ Yayın Sezonu | Ekim - Kasım - Aralık \\ Pub Date Season | October-November - December
}

Atıf/Cite as: Bakkal, Ali, Antalya Selçuklu Kervansarayları/Seljuk Caravanserais in Antalya. tarr: Turkish Academic Research Review, 4 (4), 521-570. doi: 10.30622/ tarr.644055

İntihal/Plagiarism: Bu makale, en az iki hakem tarafından incelenmiş ve intihal içermediği teyit edilmiştir. / This article has been reviewed by at least two referees and confirmed to include no plagiarism. https://dergipark.org.tr/tr/pub/tarr

Copyright (C) Published by Mehmet ŞAHİN Since 2016- Akdeniz University, Faculty of Theology, Antalya, 07058 Turkey. All rights reserved. 


\section{Antalya Selçuklu Kervansarayları}

\section{Öz}

Antalya, tarihî ipek yolu üzerinde bulunan kadim şehirlerden biridir. Anadolu Selçukluları, Antalya ve Alanya limanları vasıtasıyla dünya ticaretine ortak olmuşlar; ürettikleri ve ithal ettikleri malların ülke içinde güvenli şekilde dolaşımını sağlayabilmek için her ülkenin her tarafında kervansaraylar inşa etmişlerdir. Bu kervansaraylardan on yedisi günümüz Antalya sınırları içinde bulunmaktadır. Bunlardan sadece Kırkgöz, Alara ve Şarapsa kervansaraylarının restorasyonları tamamlanmış olup, diğerleri kendi haline terk edilmiş bulunmaktadır. Bazılarının sadece isimleri ve bulundukları bölge tespit edilebilmiş, inşa edildikleri mekan belirlenememiştir. Çoğu harabe haldedir ve bir taş yığınından ibarettir. Ancak bunlardan, kervansaraylar arasında özel bir önemi olan Evdir Han'ın taçkapısı ve bazı örtülü mekânları hala ayakta olup bir an önce restore edilmesi gerekmektedir.

Antalya kervansarayları sekiz farklı kervan yolu üzerinde bulunmaları sebebiyle Anadolu Selçukluları zamanında ticaret hayatına büyük katkı sağlamışlardır. Öyle ki bunlardan bazıları birkaç kervan yolu üzerinde bulunuyordu. Geçmişte ticaret ve konaklama açısından büyük hizmet vermiş olan bu kervansaraylar günümüzde tarih ve kültür turizmi için bize önemli imkânlar sunmaktadır.

Anahtar kelimeler: Han, Kervansaray, Selçuklu kervansarayları, Anadolu Selçukluları, Antalya, Alanya

\section{Seljuk Caravanserais in Antalya}

\section{Abstract}

Antalya is one of the ancient cities on the historical silk road. Anatolian Seljuks became partners in world trade through the ports of Antalya and Alanya; they have built caravanserais all over the country in order to ensure the safe circulation of the goods they produce and import within the country. Seventeen of these caravansaries are located within the borders of today's Antalya. Only the names of some of them and the region where they are located could be identified and the place where they were built could not be determined. Most are in ruins and consist of a pile of stones. However, the crown gate of Evdir Han, which has a special importance among the caravanserais, and some of the covered spaces still need to be restored. Antalya caravanserais were located on eight different caravan roads and contributed to the commercial life of Anatolian Seljuks. Some of them were on a few caravan paths. These caravanserais, 
which have provided great service in terms of trade and accommodation in the past, seem to be able to be used for historical and cultural tourism.

Key words: Han, Caravanserai, Seljuk Caravanserais, Anatolian Seljuks, Antalya, Alanya

\section{Giriș}

Antalya, Anadolu'nun kadim şehirlerinden biri olup tarihi ipek yolunun bazı kolları buradan geçmektedir. Özellikle Anadolu Selçukluları bu yollar üzerinde birçok kervansaray inşa ederek bunlar vasıtasıyla ticari hayatı zengin ve diri tutmuşlardır. Antalya sınırları içinde bulunan bazı kervansaraylar hakkında müstakil çalışmalar yapılmış olmakla birlikte bunların hepsini tek bir çalışmada görmek mümkün değildir. Çekül Vakfı'nın 2012 yılında yayınladı̆̆ı “'ipek Yolu Kültür Yolu Haritası"ndan dahi yeri belli olan bazı kervansarayların ismi yer almamıştır. Bizim bu çalışmadaki amacımız Antalya ili sınırları içindeki kervansarayları tespit edip bunlar hakkında kısaca bilgi vermektir. Ancak kervansaraylara geçmeden önce genel olarak bunların mahiyeti ve işlevi hakkında bilgi vermek istiyoruz.

\section{KERVANSARAYLARIN MAHIYETi VE IȘLEVI}

Antalya önde gelen bir Selçuklu şehridir ve bu şehirde köprülerden dağ yollarına, camilerden dergâhlara, medreselerden kervansaraylara, hamamlardan köşklere varıncaya kadar her türlü Selçuklu eserine rastlamak mümkündür.

Kervansaraylar, ticaret kervanlarının güvenliği ve konaklaması için şehirler arasındaki anayollar üzerinde kurulmuş olan büyük yapılardır. Geçmişte bu yapılar için han ve ribat isimleri de kullanılırdı, Kervanlar geçici olarak buralarda konaklar ve beraberlerinde getirdikleri malları pazarlarlardı (Akalın, 2002, s. 299). Bazı kervansaraylar ribat adıyla anılır. Bunlar daha çok sınır boylarında ve stratejik özelliği olan yerlerde ordunun binek hayvanlarıyla birlikte konakladığı askerî amaçlı yapılardı. Kuzey Afrika'dan Türkistan'a kadar bu tür yapıları görmek mümkündür. İslâmiyet'in genişlemesiyle birlikte bu yapıların işlevi değişmiş, genellikle şehir içlerindekiler hankâha ticaret yolları üzerinde bulunanlar ise kervansaraya dönüşmüştür (Akalin, 2002, s. 299-300).

XII. yüzyıldan sonra Selçuklular'ın hakimiyetiyle birlikte Anadolu uluslar arası ticaretin merkezi olmuştu. Selçuklu sultanları, günümüzde şehirlerin asfalt yollarla birbirine bağlanmasına benzer şekilde, gerek ana yollar gerekse ara yollar olsun Anadolu'nun her tarafina kervansaraylar inşa etmişlerdi. Vakıflar eliyle inşa edilen bu yapılarda yolcular ilk üç gün misafir sayılır, kendilerinden herhangi bir ücret alınmazdı. Ticaret kervanlarının ağırlandığı bu yapılarda sefer sırasında ordunun konakladığı da görülmektedir. Yine bu yapılarda zaman zaman yabancı hükümdarlar ağırlanmış, gerektiğinde hapishane ve sığınak olarak da kullanılmışlardır (Akalın, 2002, s. 300).

Anadolu Selçukluları zamanında Antalya ve Alanya önemli şehirler arasında yer alıyordu. Konya’dan Antalya ve Alanya’ya doğru birden fazla kervan yolu bulunuyordu ve bu yollar üzerinde 
birçok kervansaray yapılmıştı. O sıralarda Kıbrıs, Batı-Doğu ticaretinin mal deposu haline gelmişti. Kıbrıs'tan gemilere yüklenip Antalya'ya getirilen ticaret malları kervanlarla Konya'ya transfer edilir, buradan da Sinop ve Samsun'a taşınırdı (Kayaoğlu, 1981, s. 360).

Anadolu Selçukluları yol güzergâhlarında sadece kervansaray yaptırmakla kalmamış kervanların güven içinde ve rahat bir şekilde gidiş-gelişlerini sağlamak için yollar açmışlar, köprüler inşa etmişlerdir. Ticari faaliyetlere engel olmak isteyenleri ortadan kaldırmak için de çeşitli seferler düzenlemişler, tâcirlerin baskın yemeleri halinde onların zararlarını karşılamışlar veya vergi muafiyeti ve indirimi cihetine gitmişlerdir. İktisadî faaliyetlerin başında hayvancılık gelirdi. Çok miktarda koyun, keçi, at, katır, deve ve sı̆̆ır yetiştirilirdi. Süt, yăg, peynir ve yoğurt gibi mâmullerin üretimi yaygındı. Bunun yanı sıra dericilik, halı ve kilim dokumacılığı da her tarafta yapilıyordu. Suriye, Irak ve İran'a koyun ve at ile çeşitli deri ürünleri; Avrupa'ya ise ipek, pamuklu kumaş, halı, Ankara tiftiği ve börk ihraç edilirdi. Demir, bakır, gümüş, şap ve tuz Anadolu'da çıkarılan başlıca madenlerdi. Ayrıca Avrupa'ya şap, Mısır'a kereste ihraç edilirdi. Buna mukabil Karadeniz’in kuzeyinden getirilen köleler, Çin ipeği, Hint kumaşları, kürk, bal ve baharatlar Anadolu'nun çeşitli şehirlerinde pazarlanırdı (Kucur, 2009, s. 384).

Türk devlet anlayışının temel amaçlarından biri, sultanın, halkını maddî ve manevî açıdan mutlu etmesidir. Yani, "Kağan oturup aç, fakir milleti hep toplamak, fakir milleti zengin, az milleti çok, çılak milleti elbiseli, aç milleti tok kılmak"tır. Kısacası sultan, toprağında yaşayan insanlar arasında hiçbir fark gözetmeksizin hepsini refah içinde yaşatmakla mükelleftir. Sözü edilen bu genel prensip uyarınca, Selçuklu Sultanları iktisadî ve ticarî kalkınmayı sağlamak için, bir takım sistemli ve planlı politikalar izlemişler, bunda da büyük ölçüde başarılı olmuşlardır. (Bedirhan, 2018, s. 117).

Kesme taş kaplı yapısı ve destek kuleleriyle güçlendirilmiş yüksek duvarlarıyla ihtişamlı bir kaleyi andıran Selçuklu kervansarayları, kervanların güvenliği kadar, kervanlarla yolculuk yapan kişilerin her türlü ihtiyacını karşılayacak şekilde düzenlenmiş bulunuyordu. Buralarda yolcular, barınma ve yemek imkânlarının yanı sıra hamam, mescid, eczahane ve gerektiğinde doktor ihtiyaçlarını karşılayabiliyorlardı. Fakir yolculara bedava ayakkabı, hayvanlar için yem, nalbant, veteriner, araba tamiri gibi hizmetler sunulurdu. (Akalın, 2002, s. 300).

Anadolu Selçukluları Dönemi'ndeki ana kervan yolları şu şekildeydi:

a. Doğu-batı yönündeki güzergâh: Antalya ve Alanya'dan çıkıp, Konya, Aksaray, Kayseri, Sivas, Erzurum ve Erzincan gibi büyük kentlerden geçerek İran ve Türkistan’a ulaşırdı.

b. Konya - Batı Anadolu - İstanbul güzergâhı: Konya'dan çıkan diğger bir yol Akşehir üzerinden Batı Anadolu ve İstanbul'a giderdi.

c. Güney - kuzey istikametindeki güzergâh: Misır, Suriye veya Avrupa limanlarından gelen mallar doğrudan ve Kıbrıs aracılığıyla Antalya veya Alanya limanları vasıtasıyla Türkiye’ye girerdi. Sonra Konya, Kayseri, Sivas, Tokat üzerinden Sinop veya Samsun limanlarına getirilirdi. Oradan da deniz yoluyla kuzeyin en önemli limanı olan Suğdak’a ulaşılırdı. 
d. Konya - Doğu Anadolu - Irak güzergâhı: Konya'dan çıkan bir yol Kayseri’den geçerek E1bistan, Malatya, Diyarbakır üzerinden Doğu Anadolu ve Irak’a ulaşırdı.

e. Tali Yollar: Anadolu'nun her tarafında yukarıda sağdığımız ana yollara bağlanan birçok tali yol bulunuyordu. Ana yollar üzerinde olduğu gibi bu yollar üzerinde de çeşitli kervansaraylar vardı. Mesela Malatya'dan çıkıp çevre illere giden 6 ayrı yol güzergâhı tespit edilmiştir. Malatya-Kahta, Malatya-Elbistan, Malatya-Divriği, Malatya-Sivas ve Malatya-Harput güzergâhları bu yollardandır. Bu güzergâhlarda, menziller arasındaki mesafeler, 3 ila 18 kilometre arasında değişmektedir. Diyarbakır-Bitlis, Konya-Hatunsaray-Seydişehir ve Konya-Eğridir yollarında da aynı yoğunlukta kervansaraylar tespit edilmiştir (Aytaç, 2018). Antalya veya Alanya'dan çıkıp Denizli, Kubadâbâd, Konya ve Adana istikametlerine giden yolların Antalya il hududu içinde kalan kervansaraylar arasındaki ortalama mesafenin de $25 \mathrm{~km}$ civarında olduğu anlaşılmaktadir.

TC. Kültür ve Turizm Bakanlığı Kültür Varlıkları ve Müzeler Genel Müdürlüğü Denizli-Doğubayazıt kervan yolu üzerinde bulunan kervansarayları örnekleyerek UNESCO Dünya Miras Listesi’ne aday göstermiştir. Bu güzergâh üzerinde bulunup isimleri tespit edilebilmiş olan han ve kervansarayların adları şöyledir: "Akhan, Pınarbaşı Han, Eğridir Han, Pınarpazarı Hanı, Kantarcı Han, Obruk Han, Oklu Han, Sultan Han (2), Akhan, Ağzıkarahan, Sünnetli Han, Sikre Han, Ertokuş Han, Kireli Han, Elikesik Han, Kavak Han, Kuruçeşme Han, Altınapa Han, Sadettin Han, Zincirli Han, Akbaş Han, Öresin Han, Han Camisi, Sultan Han, Şahruk Köprüsü Han, Lala Kervansarayı, Gedik Han, Latif Han, Mugar Han, Cibci Han, Pervane Han, Kargı Han, Köprüköyü Hanı, Mamahatun Kervansarayı, Hacı Bekir Han” (Selçuklu Kervansarayları Denizli Doğubayazıt Güzergâhı). Denizli-Doğubayazıt arası 1585 km. olup bu güzergâh üzerinde 37 han bulunmaktadır. Buna göre her $42.8 \mathrm{~km}$.ye bir han düşmektedir. Gerçekte kervansaraylar arasındaki bu mesafe daha azdır. Muhtemelen bu güzergâh üzerinde bulunan bazı hanlar tamamen tahrip olup yerleri belirsiz hale geldiği için isimleri tespit edilememiştir.

Anadolu Selçukluları devrinde ticaretin önem kazandığ1 1. Keyhüsrev, 1. Keykavus ve 1. Alaeddin Keykubat devirlerinde, yalnız 1204-1243 yılları arasında, Anadolu'da kırk civarında kervansaray yaptırılmıştır. Anadolu'da Selçuklular tarafindan yaptırılan kervansarayların toplam sayısı ise 90 civarındadır. Selçuklu sultanları Anadolu'da ticaretin gelişmesine çok önem vermişlerdir. Gemilerle limanlara veya Orta Asya'dan direkt yolla gelen baharat ve ipekli kumaş gibi o zaman çok revaçta olan mallar hep kervanlarla bir yerden diğer yere naklediliyordu (Korkmaz, 2009, s. 40).

Selçuklu kervansarayları askerî bakımdan büyük önem arzettikleri gibi, ticarî siyaset bakımından da şu iki önemli amacı taşıyordu:

a) Zengin ticaret mallarını nakleden kervanlara, sınır boylarında düşman çapulcularından, göçebe ve eşkıya baskınlarından koruyacak güvenli konak yerleri sağlamak. Bu sebeple kervan- 
sarayların duvarları sur gibi çok sağlam şekilde yapılmış; çevre duvarlarının üzerine kuleler ve burçlar inşa edilmiş; kapıları demirden yapılmıştır. Bu şekilde kervansaraylar her türlü tehlikelere karşı koyabilecek bir müdafaa tertibatıyla donatılmı̧ bulunmaktaydı.

b) Kervansarayların inşasında ikinci önemli amaç, yolcuların konakladıkları bu tür mekânlarda her türlü ihtiyaçlarını temin etmek idi. Kervansarayların bu fonksiyonları da son derece önemliydi. Kervansarayların hemen tamamında yatakhane, aşhane, erzak ambarı, ticari eşyaların konulduğu depolar, yolcuların hayvanlarını bağladıkları ahırlar, samanlık, mescit, hamam, şadırvan ve hastane gibi birimler bulunurdu. Hatta bazı kervansaraylarda yolcuların ayakkabılarını tamir ve fakir yolculara yenisini yapmak için ayakkabıcı, hayvanları nallamak için nalbant vardı. Bütün bu ihtiyaçları karşılamak için bir teşkilat vardı ve yine ilgili birimlerin giderlerini karşılamak için malî bir sistem oluşturulmuştu. Kervansarayların hemen tamamı vakıf idi, kurucuları da çoğunlukla Selçuklu sultanlarıydı. Yine hemen tamamı zengin vakıflara sahipti. Kervansaraylara gelen tüccar ve diğer yolcular, zengin olsun fakir olsun, herhangi bir ücret ödemeden buralarda konaklayabilirler ve kaldıkları süre içinde de her türlü ihtiyaçlarını görebilirlerdi (Turan, 2018).

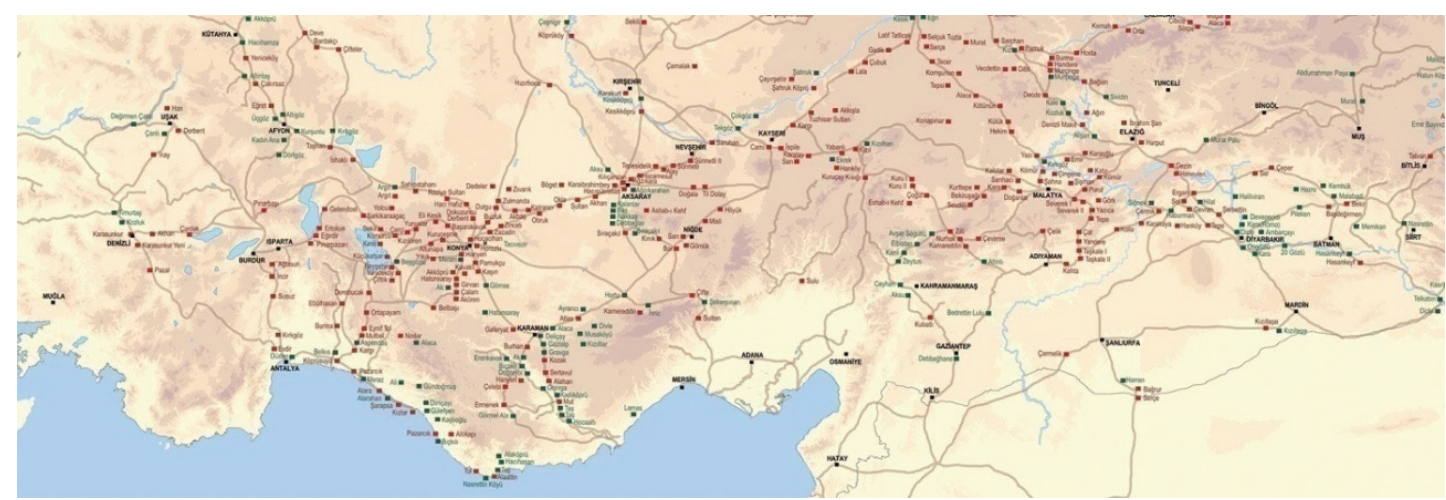

Harita 1: Çekül Vakfínın 2012 yılında tamamladığ İpek Yolu Kültür Yolu haritası (https://www.cekulvakfi.org.tr)

\section{ANTALYA SINIRLARI IÇINDEKI SELÇUKLU KERVANSARAYLARI}

Selçuklular döneminde Antalya birçok malın üretildiği bir merkez olmanın yanı sıra Antalya ve Alanya limanlarıyla Mısır, Suriye, Irak ve Avrupa'dan gelen malların Anadolu topraklarına giriş yeriydi. Buraya inen mallar başta başşehir Konya olmak üzere Anadolu'nun her tarafina gönderilirdi. Bu nedenle Antalya önemli bir ticaret şehriydi ve bütün yollar bir şekilde Antalya ve Alanya'ya çıkmaktaydı. Konya civarında olduğu gibi tacirleri ve ticarî mallarını emniyet altına almak ve yolcuların her türlü ihtiyaçlarını karşılamak için ortalama her 25 km’ye bir kervansaray düşecek şekilde birçok kervansaray tesis edilmiştir. Tespit edebildiğimiz kadarıyla günümüzde Antalya sınırları içinde Anadolu Selçukluları tarafından 30 dolayında kervansaray inşa edilmiş bulunmaktadır. Bunların bir kısmı neredeyse temellerini dahi tespit etmede güçlük çekilecek kadar harap olmuş vaziyettedir, bir kısmı da günümüze bir hayli sağlam olarak gelmiştir. Şimdi bu kervansarayların her biri hakkında kısaca bilgi vermeye çalışacağız: 


\subsection{Antalya-Burdur Güzergâhındaki Kervansaraylar}

\subsubsection{Evdir Han (1211-1220)}

Yeri:

Evdir Han, Antalya - Korkuteli yolu üzerinde Döşemealtı ilçesi sınırları içinde Yukarı Karaman Düzlerçamı mevkiinde yer alan bir Anadolu Selçuklu kervansarayıdır. Termessos antik kentinin kalıntıları üzerine kurulmuştur. Antalya şehir merkezine $18 \mathrm{~km}$. uzaklıktadır. Korkuteli yolu üzerinde bulunması sebebiyle "Korkuteli Han" adıyla da anılmaktadır. Evdir Han, hem Antalya-Denizli, hem de Antalya-Burdur istikametlerindeki yol güzergâhlarının ilk menzilidir.

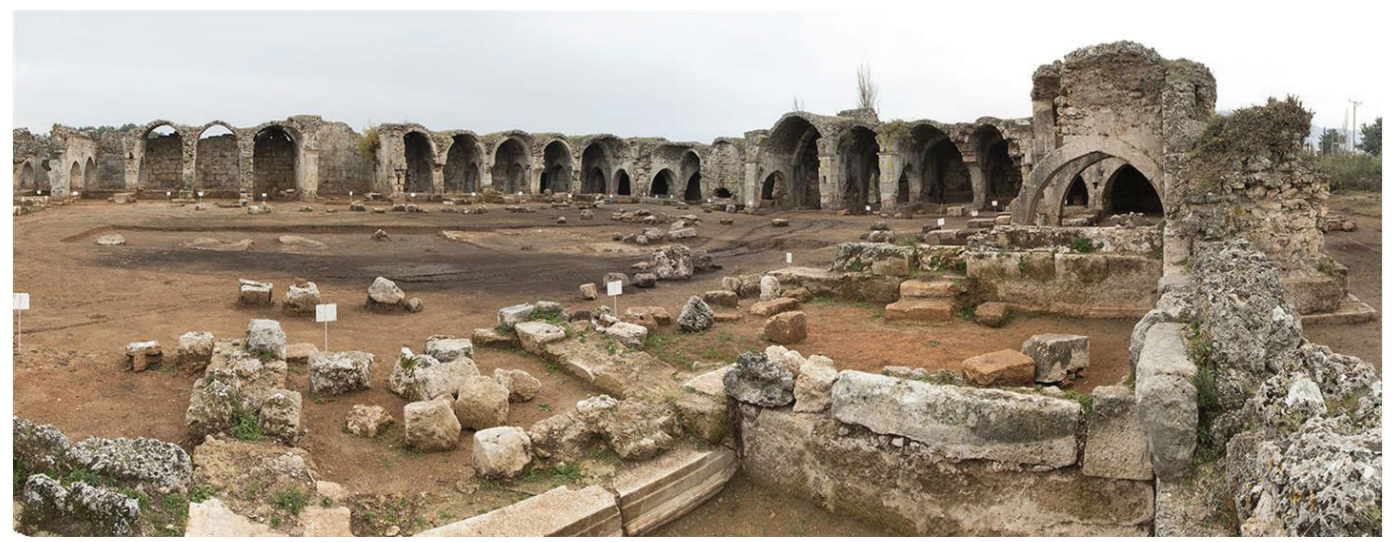

Resim 1: Evdir Han'1n içinden bir görüntü (dosemealti.bel.tr)

\section{Kitâbesi, bânisi ve inșâ tarihi:}

Kervansarayın üç satırlık mermer kitabesi bugün yerinde bulunmamaktadır. Ancak bu kitabe 1928 yılında mevcuttu ve tarihi dahil bir kısmı eksik olmasına rağmen R. Riefstahl tarafından okunmuştu. Buna göre kervansarayın, I. İzzeddin Keykâvus zamanında 1211-1220 y1lları arasında inşa edildiği anlaşılmaktadır (Durukan, 1995, s. 516). 1940 y1lında taç kapısı üzerinde bulunan kitabe Fikri Erten tarafından yayınlanmıştır. Daha sonra kitabe yerinden sökülerek Yeşil Bayır Köyü'ndeki okul bahçesine götürülmüş, sonrasında ise kaybolmuştur (Eravşar, 1917, s. 546). Kitabede şunlar yazmaktadır:

“es-Sultânü'l-gâlib ‘İzzü’d-dünya ve'd-dîn Sultânü'l-me‘âlî, aliyyetün devletühû... 'Adlü’l-âlemîn ... Ebü'l-Feth Keykâvus b. Keyhusrev Bürhânü Emîri'l-mü’minîn Cemâziye'l-evvel ... 10 ... : Muzaffer sultan, Din ve dünyanın şerefi, Devleti güçlü yüce padişah, Âlemlerin âdili..., Fethin babası, Keykâvus b. Keyhusrev, Müminlerin emîrinin bürhanı. Cemâziyelevvel ... $10 \ldots "$ 


\section{Planı ve yapı özellikleri:}

Evdir Han, açık avlulu, dört ana eyvanlı plan tipinin Anadolu'daki iki örneğinden biridir. Bu itibarla Evdir Han ayrı bir önem taşır. Benzer bir plana sahip olan diğer kervansaray, Şanlıurfa ili Harran ilçesinin 30 km. güneydoğusunda yer alan 1215 tarihli Han el-Ba 'rûr'dur. Anadolu'da pek benimsenmediği anlaşılan bu plan tipi, diğer Selçuklu bölgelerinde yaygın olarak karşımıza çıkmaktadır (Durukan, 1995, s. 516).

Kervansaray kuzey-güney doğrultusunda inşa edilmiş düzgün dikdörtgen planlı bir yapıdır. $54,00 \times 67,60 \mathrm{~m}$. ölçülerindeki yapı, yaklaşık olarak 3650 metrekarelik bir alanı kapsamaktadır. Doğu ve batı cephelerinde üçer, diğer cephelerinde ikişer tane olmak üzere çevresinde toplam on adet dört köşe payandası vardır. Güney cephede eksen üzerinde yer alan taç kapı dışa taşmış vaziyettedir. Girişin karşılıklı cephelerinde birer mihrabiye nişi yer almaktadır. 34,50 × 45,10 m ölçülerindeki dikdörtgen planlı açık avlu dört yönden, çift sıra taş ayaklara basan tonozlarla örtülü derin eyvanlarla kuşatılmış bulunmaktadır. Bunlardan giriş eyvanı ve onun karşısına rastlayan eyvan ile yan eksenlerde bulunan diğer iki eyvan yüksek ve geniştir, diğerleri galeri ölçülerindedir. İçte, yapının doğu duvarında kuzeyden dördüncü birime ve güney duvarında batıdan üçüncü birime açılan birer kapıdan, bugün yalnızca üçer basamağ1 görülebilen birer merdivenle dışa payanda olarak yansıtılmış dikdörtgen planlı küçük mekânlara çıkıldığı anlaşılmaktadır; bu kısımların gözetleme kulesi olarak kullanıldığı düşünülmektedir (Durukan, 1995, s. 516).

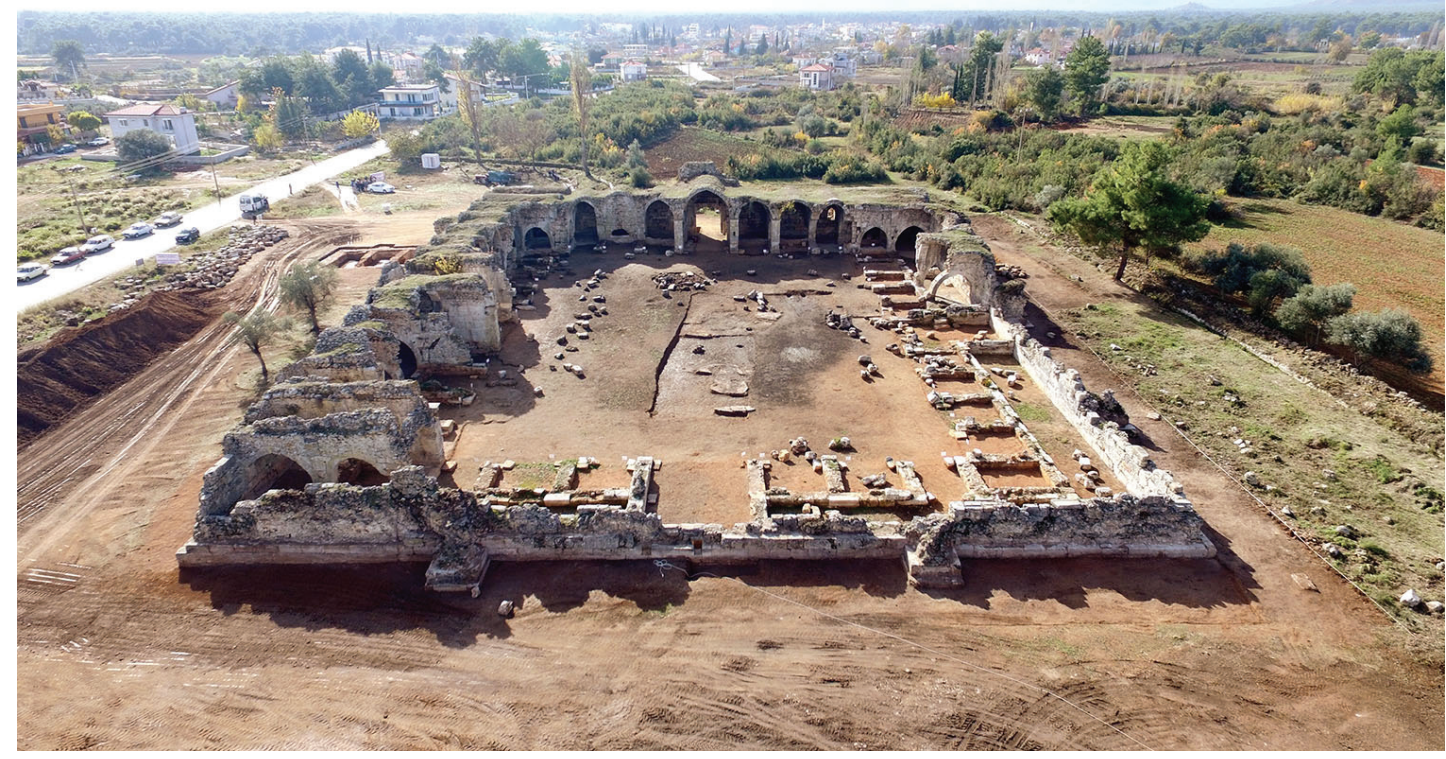

Resim 2: Evdir Han'ın havadan görünüşü (dosemealti.bel.tr)

Bölgeye gelen seyyahlardan Corancez, Evdir Han'ın ismini vermeden yapının büyük bir deprem sonucunda yıkıldığını ifade eder (Eravşar, 2017, s.538). Yüksek bir ihtimalle Evdir Han'1 y1kan deprem, 1743 tarihli Antalya depremidir. Bu deprem, Antalya Limanı'nın bir süre kurumasına, farklı bölgelerde şehir surlarının belli kısımlarının yanı sıra birçok evin yıkılmasına 
neden olmuştur. Bu deprem sebebiyle bölgedeki birçok köy haritadan silinmiş; bugün "Siçan Adası” diye bildiğimiz Sultan Reşat Adası'nın bulunduğu bölgede, adanın batı cihetinde bir dağ parçası yerinden ayrılıp suya düşmüş ve tamamen batmıştır (Cimrin, 2016).

Kervansarayın bütününde, moloz dolgu üzerine oldukça düzenli teknikte kesme taş kaplama yapılmıştır. Taşların üstünde çok sayıda değişik taşçı işareti bulunmaktadır. Antik şehrin nekropolü üstünde yer alan kervansarayda fazla miktarda devşirme malzeme kullanıldığ1 görülmektedir.

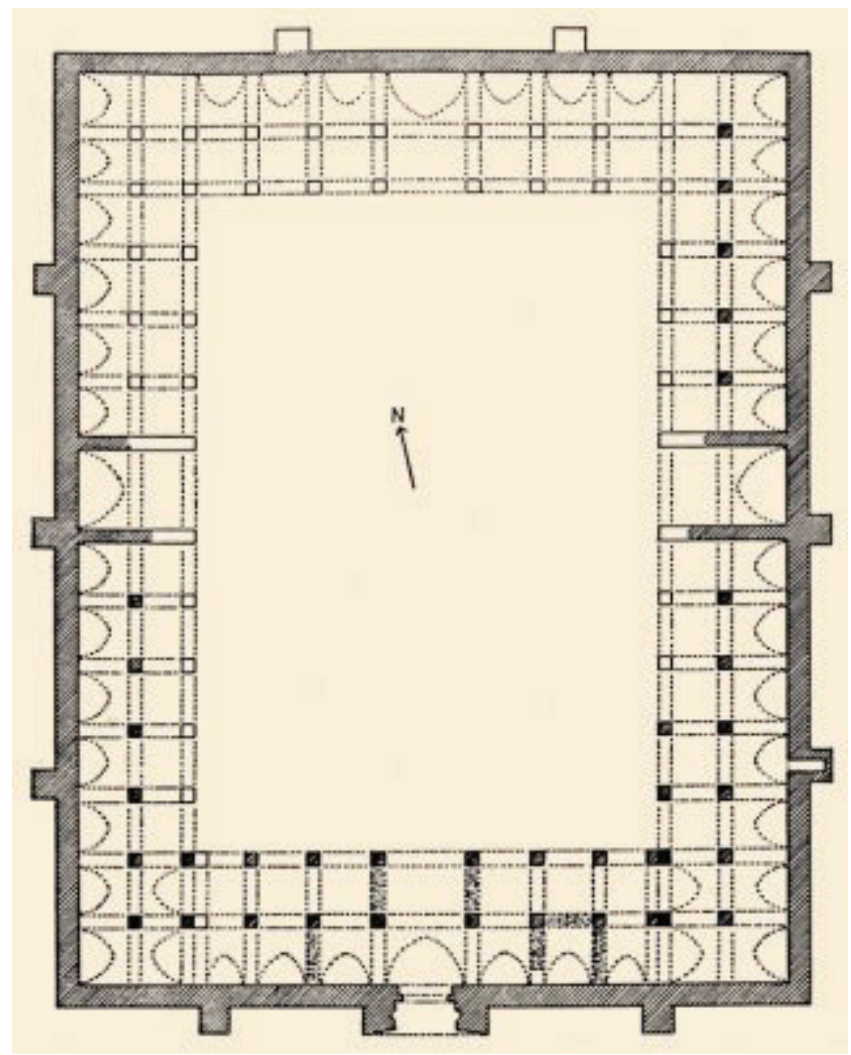

Şekil 1: Evdir Han'ın Planı (DİA, XI, 516)

"Hanın cephe duvarlar 1,50 m kalınlı̆ga sahiptir. Kemerlerin üzerlerine oturtulmuş 7,30 m yüksekliğinde tonozlarla örtülü gözler vardır. Bu gözler orta avluya bakmakta olup, hana gelen yolcuların bayvanların bağlayıp, yüklerini de koyma işlevi görür. Hanın ayrıca yolcular için odaları vardır. Içeride bu odalardan başka hayvanlar için ahırlar da mevcuttur. Hanın yakın çevresinde akarsu bulunmadiğı için, bölge halkı tarafindan uzun kuyu olarak adlandırılan hanın su ibtiyacı için bir de sarnıç yaptırılmıstır" (Evdir Han). 


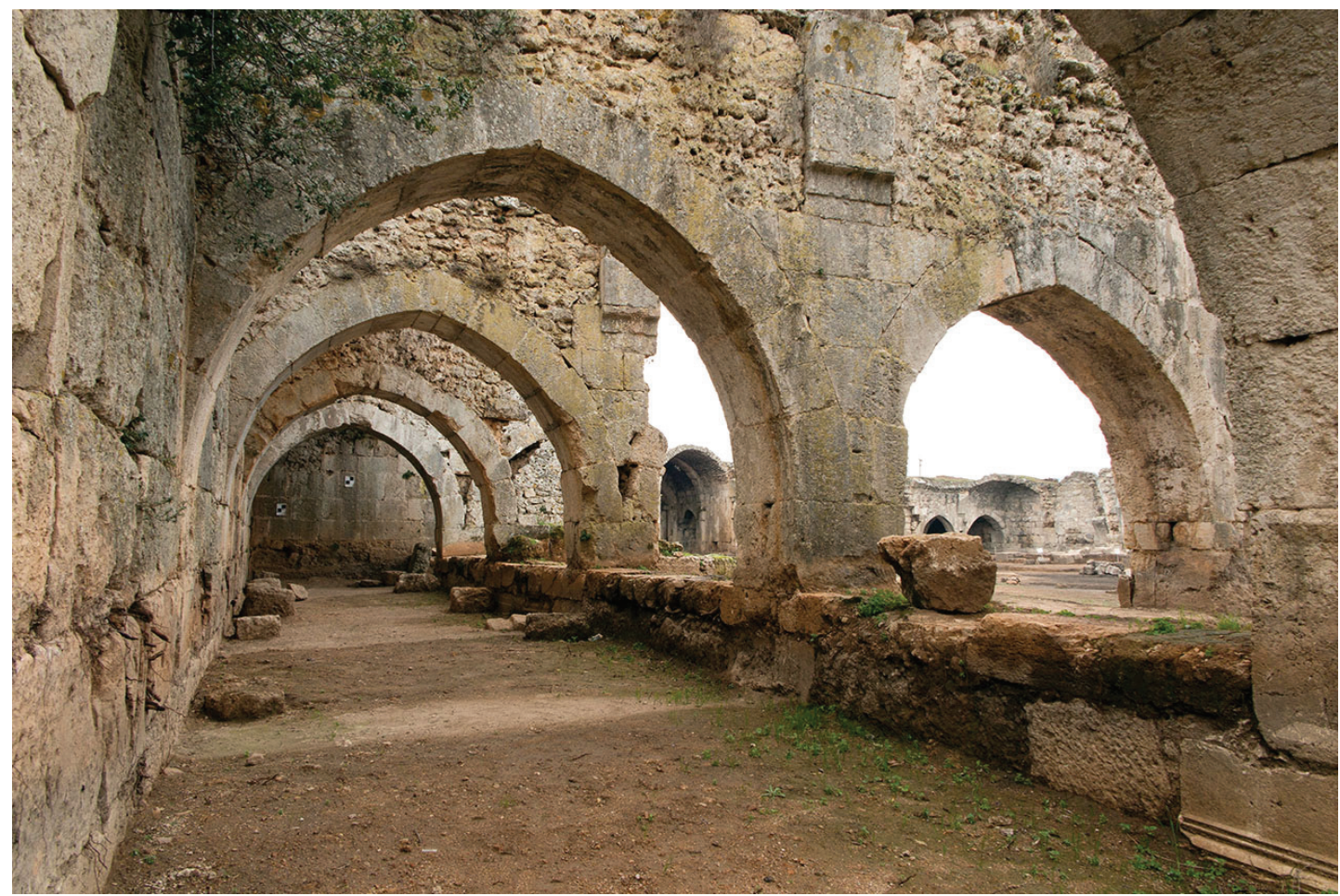

Resim 3: Evdir Han’ın içinden bir görünüs (dosemealti.bel.tr)

\section{Taçkapısı:}

Evdir Han'ın taçkapısı, Türk taş ve oymacılık sanatının en güzel örneklerinden birisidir. Taç kapıyı üç yönden kuşatan geometrik geçme şerit süslemeleri açısından, şeritlerin azaldığ1, fakat sayılarının çoğaldığı portallerin ilk örneği sayılmaktadır.

Dört eyvanlı hanlar grubunda bulunan yapının özellikle taç kapısı dikkat çekicidir. Beden duvarından ileri çıkıntı yapan portalin üst iki köşesi yıkılmıştır. En dışta ince bir bordür onun içinde de sonsuza açılan yıldızlardan kalınca bir bordür sırası bulunur. Bu ikisinin üst kısımları yok olmuştur. Üçüncü bordür sırası ise geometrik şekillerden oluşmaktadır. Taç kapının sivri kemeri sanki küçük sütunceler tarafından taşınıyormuş gibi şekillendirilmiştir. İçe devam eden nişin iki yan duvarında birer küçük mihrabiye bulunmaktadır. Taçkapı nişinin üst kısmı ise mukarnaslarla doldurulmuş ve kapı basık kemer ile sonlandırılmıştır (Durukan, 1995, s. 517; Antalya İl Kültür Müdürlüğü, 2012, s. 285-286). Büyük ölçüde mermer kullanıldığ1 görülen taç kapıda değişik süslemelerle karşılaşılmaktadır. "Hemen hemen tamamıyla bezemeli olan bu kısımda değişik geometrik motifler uygulanmıştır. Nişi dıştan iki dendan dizisiyle beş on kollu yıldız geçmelerle süslü geniş bir şerit kuşatır. Sivri kemerin yüzeyinde ve basık kemerin üzerindeki yatay şeritte düğüm motifleriyle birleşen daireler ve içlerinde baklava dilimleri görülür. Mukarnaslar yelpaze ve istiridye motifleriyle süslüdür” (Durukan, 1995, s. 517). 


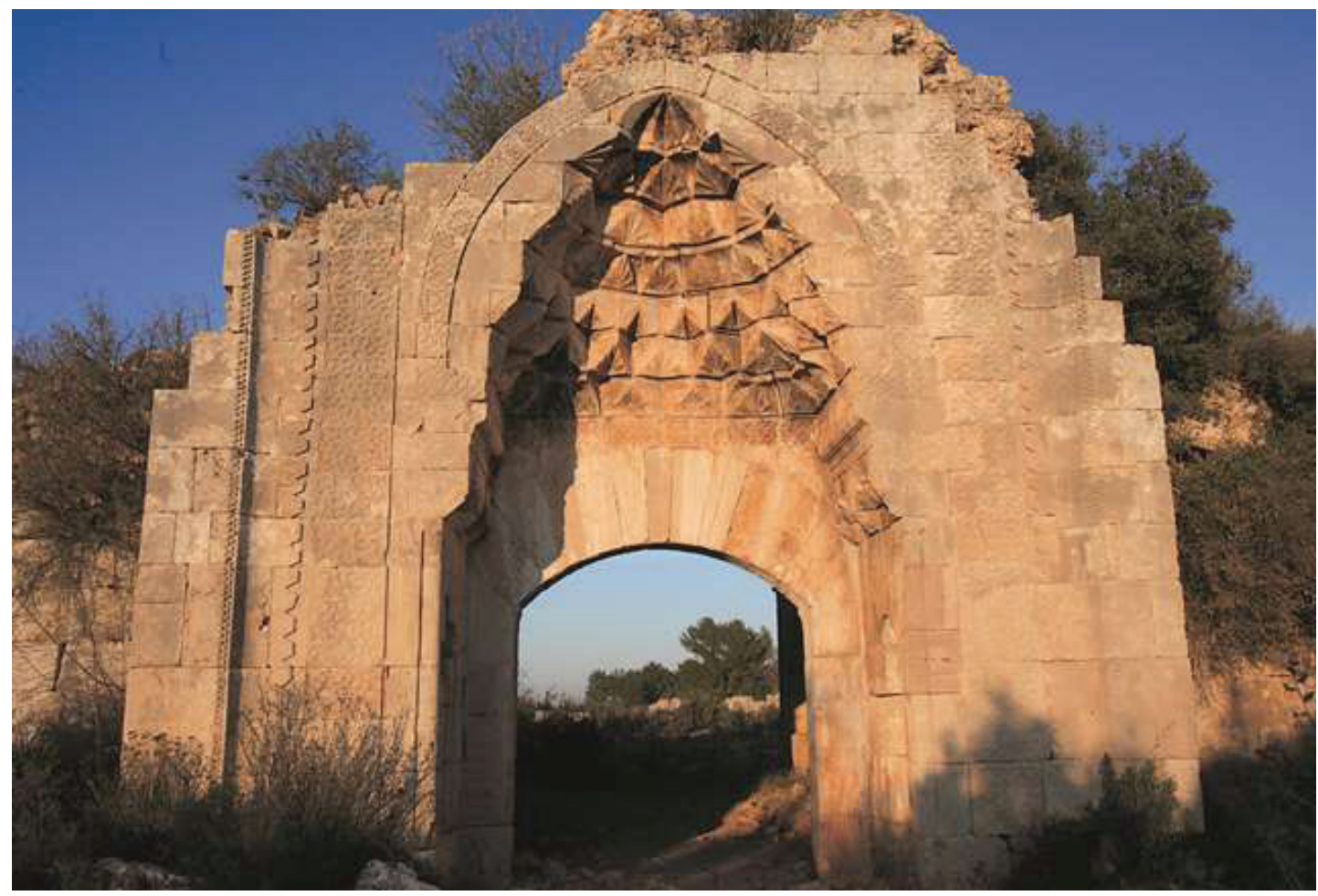

Resim 4: Evdir Han'ın Taçkapısı (turkishhan.org)

\section{Mescit:}

Selçuklu kervansaraylarında mutlaka bir mescit bulunurdu. Ancak Evdir Han'da hangi mekânın mescit olarak kullanıldiğ tam olarak tespit edilememiştir. Girişin batısında bulunan merdiven birçok Selçuklu kervansarayında olduğu gibi mescidin üst kata yerleştirilmiş olduğunu akla getirmektedir. Ancak yapılan analizlerden mevcut merdivenin mescit için yeterliği olmadĭ̆ anlaşılmaktadır. Muhtemelen giriş kısmının să̆ ve solundaki mekânlardan biri mescit olarak kullanılmıştır.

\section{Restorasyonu:}

Evdir Han 'la ilgili olarak Akdeniz Üniversitesi ile Rölöve, Restitüsyon ve Restorasyon projesi protokolü imzalanmıştır. Restorasyon tamamlandığında Selçuklu'da "Han Hayatı Müzesi" ile "Dokumacılık Müzesi" oluşturulmak suretiyle hem dönemin tarihi yaşatılmış olacak, hem de bölgenin en önemli kültürel etkinliklerinden "Döşemealtı Halısı” aynı çatı altında toplanmiş olacaktır. 


\subsubsection{Kırkgöz Han (634-644/1236-1246)}

\section{Yeri:}

Evdir Han'dan sonra Antalya-Burdur istikametindeki ikinci menzil Kırkgöz Han'dır. Kırkgöz Han, Antalya-Burdur yolu üzerinde Döşemealtı ilçesi Bıyıklı köyü sınırları içinde karayolundan yaklaşık 300 m kadar içeride yer almaktadır. Burdur istikametinde Antalya'ya yaklaşık 30 km. mesafede meşhur Karain mağarasının $3 \mathrm{~km}$ alt tarafında, Antalya şehir merkezine $33 \mathrm{~km}$ uzaklıktadır. Antalya - Burdur yolu istikametinde Evdir Han'dan sonra ikinci menzildir. Evdir Han'la arasındaki mesafe $15 \mathrm{~km}$ civarındadır.

\section{Kitâbesi, bânisi ve inșâ tarihi:}

Taçkapının üst kısmında mermer üzerine yazılmış altı satırlık bir kitâbe mevcuttur. Kitâbe genelde sağlam olmakla birlikte bazı yerlerde harf ve kelimeler silinmiştir. Bu haliyle de kitâbeden kervansarayın yapılmasını Anadolu Selçuklu Sultanı Keyhüsrev b. Keykubad'ın (1237-1246) emrettiği açık olarak anlaşılmaktadır. Kitâbenin sonu 13 rakamıyla bitmektedir. $\mathrm{Bu}$ rakam bize kervansarayın hangi y1l inşâ edildiği konusunda kesin bilgi vermemekle birlikte, II. Gıyâseddin Keyhürev'in dokuz yıllık saltanatı dönemi içinde yapıldığı açıktır. Bazı araştırmacılar, Kırkgöz Han'ın Eğirdir Han, İncir Han ve Susuz Han'la aynı dönemde yapıldıkları kanaatindedirler. Çünkü II. Gıyâseddin Keyhusrev bu güzergâha çok önem veriyordu. (Eravşar, 2017, s. 508). Biz de bu düşünceye katılmaktayız.

Kitabenin bir özelliği de Sultan'ın, daha önceki Selçuklu hükümdarlık alâmetleri arasında hiç görülmeyen "taç, sancak ve kuşağın sahibi” olmakla tasvir edilmesi, ayrıca ilk kez bu kitabede kervansarayda doğudan batıya seyahat edenlerin misafir edileceğinin ifade edilmiş olmasıdır. Bu özelliği itibariyle Kırkgöz Han’ın kitabesi özgün bir örnek sayılmaktadır (kulturportali).

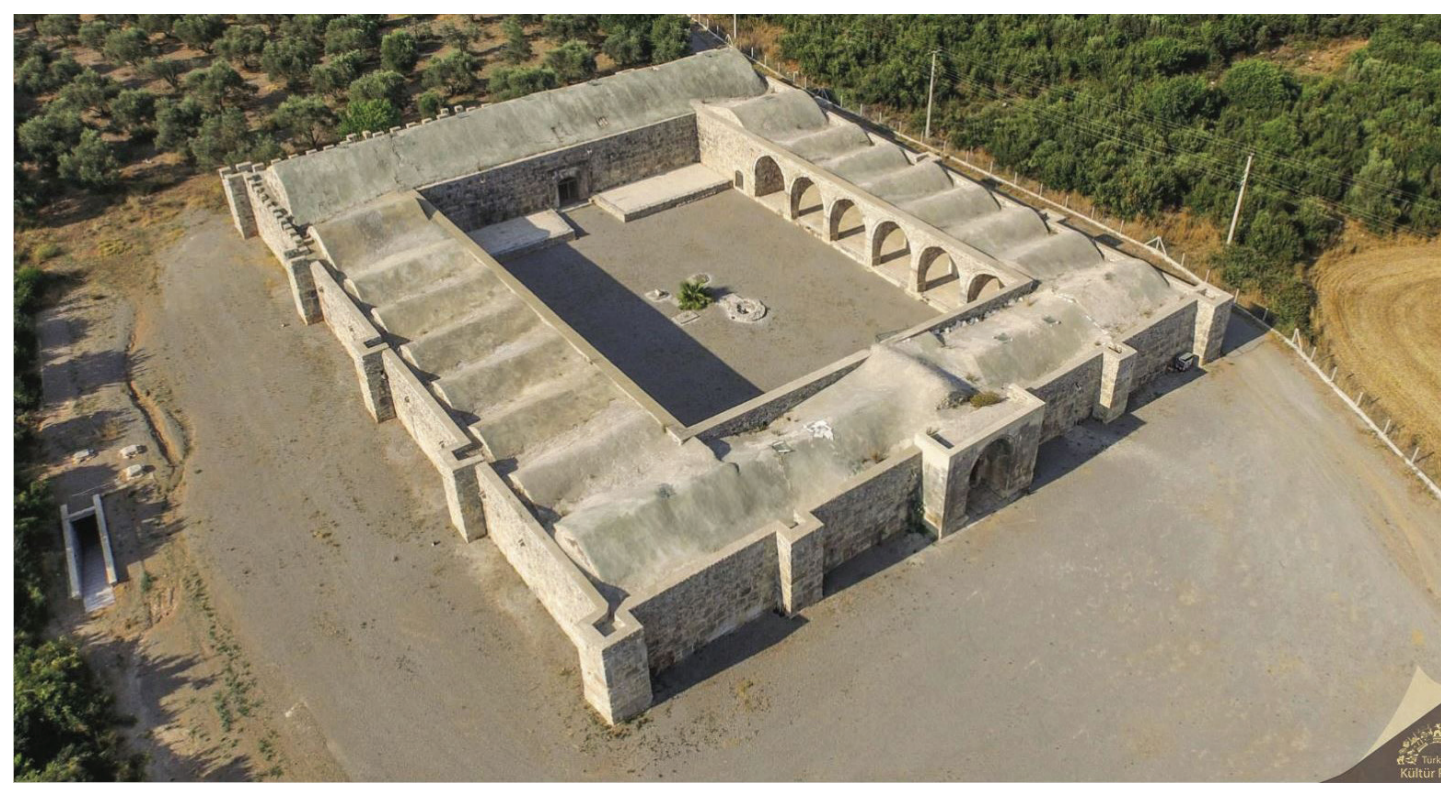

Resim 5: Restorasyondan sonra Kırkgöz Han (Görsel sahibi: Konya Selçuklu Belediyesi) 


\section{Planı ve yapı özellikleri:}

Kırkgöz Han, avlunun yapıya hakim olduğu hanlar grubunda değerlendirilmektedir. Karg1 Han ve Şarapsa Han ile ortak benzer özellikleri vardır (Eravşar, 2017, s. 513).

Kırkgöz Han, kareye yakın dikdörtgen planlı bir yapıdır. Planında daha önce yapılmış kervansarayların klasik şemasına nisbetle bazı farklılıklar görülmektedir. Yatık dikdörtgen hol bölümü tonozla örtülüdür. Hol bölümünün önünde revaklı avlu yer alır. Han'da genel olarak Evdir Han'ın planını tekrarlanmış olmakla birlikte, avluda, girişin iki yanında ve hole bitişen bölümlerde revakların yerine tonozlu mekânların konması bakımından ondan ayrılır (Akalın, 2002, s. 301).

Kırkgöz Han’ın yapı özellikleri hakkında Osman Eravşar şu bilgileri verir:

"Han, hem yazlık hem de kışlık barınma imkânı sağlayan iki ana gövdeli hanlardandır. Kuzey-güney yönünde hafifçe eğilimli bir arazi üzerinde kurulmuştur. Hizmet birimlerini barındıran mekânlar hanın güneyine yerleştirilmiştir."

"Araziye enlemesine oturtulan kapalı kısmın üzeri doğu-batı doğrultusunda uzanan tek bir beşik tonozla örtülmüştür. Beşik tonoz eşit aralıklarla atılan altı kaburga kemerle desteklenmiştir."

"Doğu-batı duvarında bulunan mazgal pencerelerle aydınlatılmıştır. Ayrıca kaburga kemerler arasına, tonozların tam ortasında denk gelecek şekilde birer aydınlık açıklığı yerleştirilmiştir.”

"Barınak bölümüne girişte, holü tam ortalayacak şekilde yerleştirilen sekinin bazı kısımları günümüze ulaşmıştır. Taş duvar örgülerinden bir kısmı sağlam olan bu mimari parçanın seki olduğu toprak dolgu malzemesinden anlaşılmaktadır."

"Yapının kuzeyinde eşit aralıklarla yerleştirilmiş dikdörtgen kesitli dört kule payanda ile köşelerde kare kesitli birer destek kulesi bulunur."

"Yapının çatısında aralıklı olarak, oyuklu yataklar görülmektedir. Bunlar alaturka oluklu kiremitlerin zamanla yıpranmasıyla ortaya çıkan harç izleridir. Giriş cephesinde yağmur oluklarının sağlam kalan parçaları da fark edilmektedir.” (Eravşar, 2017, s. 508).

Yapının avlu bölümü barınak kısmının neredeyse üç katı büyüklüğünde bir alana kaplamaktadır. Avlunun güney kanadında, aralığın bitiminde eyvan yer almaktadır. Eyvanın iki yanında üzeri beşik tonozla örtülü, girişi basık kemerli dikdörtgen birer oda bulunmaktadır. Doğu tarafina düşen odalarda yapılan kazılarda bir kanal açığa çıkarılmıştır."

“Avlunun doğu ve batı kanadında iki destek sırasıyla desteklenen ve ayakları doğu-batı yönünde birbirine kemerle bağlanan, üzerlerin avluya doğru yönelen sivri beşik tonozla örtülmüş revaklar bulunur. Karş1lıklı yedişer bölümden oluşan revaklardan güney cephedeki ilk oda tek destek öğesine sahiptir. Burası sofaya değil, önündeki dikdörtgen planlı mekâna bakar." (Eravşar, 2017, s. 511). 


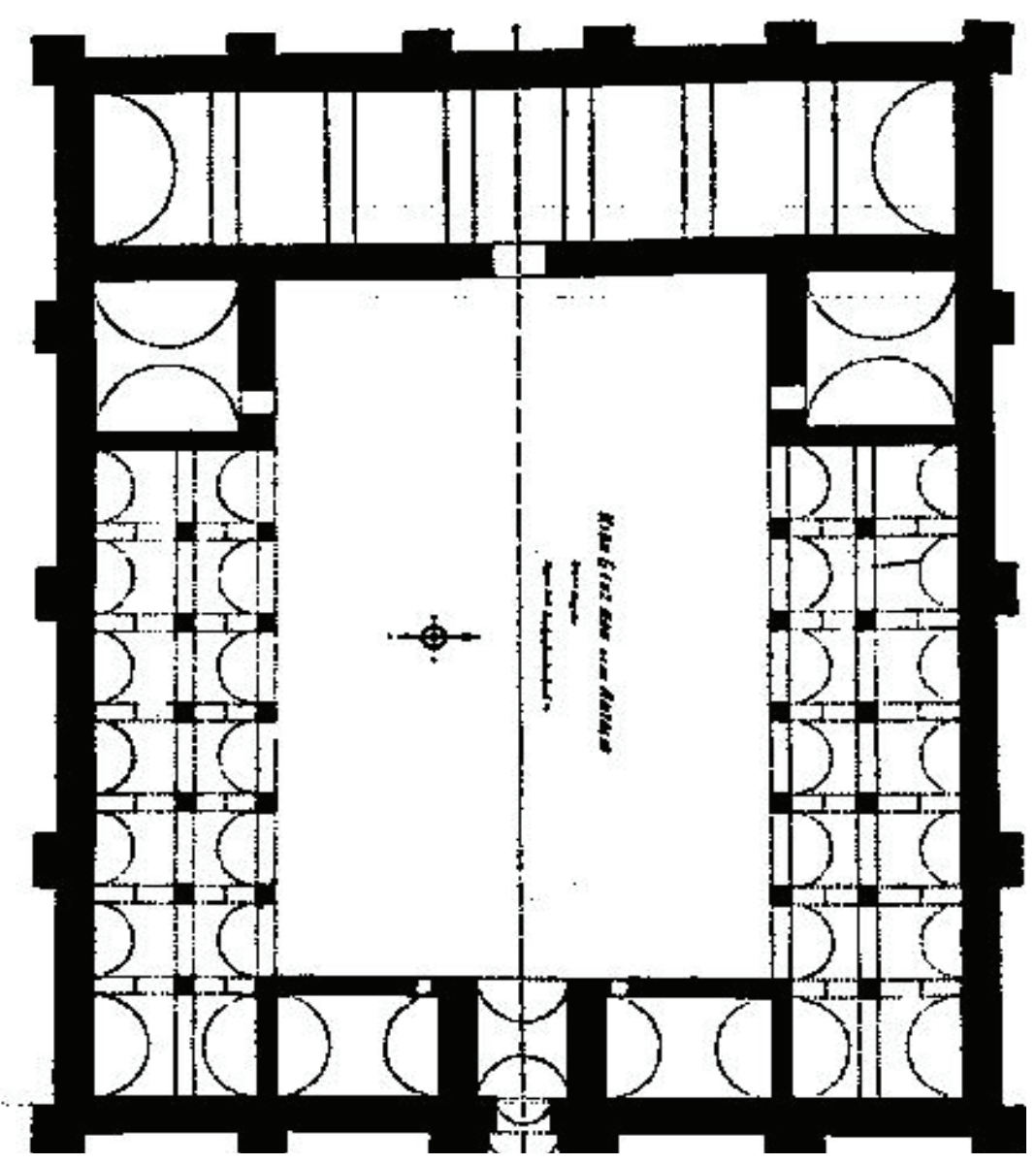

Şekil 2: Kırkgöz Han, Plan Rölövesi (R. M. Riefstahl)

İklim nedeniyle yapının içinde ocaklar bulunmamaktadır. Çoğunluğu itibari ile sağlam olarak ayakta duran yapının beden duvarlarında moloz taş kullanılmıştır (Antalya İl Kültür ve Turizm Müdürlüğü, 2012, s. 285).

Giriş sol tarafındaki köşe hamamdır. Avlu tarafındaki duvarda suyun içeriye girmesi ve diş ana duvarda da suyun dışarıya çıkması için birer delik bulunmaktadır. Yine sol tarafta avlunun bittiği yere bakan en son odada aydınlık bulunmamaktadır. Burasının kiler olduğu tahmin edilmektedir. Avluda girişin sağ orta tarafa yakın yerde bir de kuyu bulunmaktadır. Bu kuyu kervansarayın su ihtiyacını karşılamak için açılmıştır.

\section{Taçkapı:}

Hanın taç kapısı, yapının güney duvarının ortasında, güney duvarıyla hem-yüz olacak şekilde inşa edilmiştir. Köşelerde yer alan payandalarla aynı hizayı biraz aşacak şekilde hafifçe dışarıya taşırılmıştır. Kapıdan içeri girilince ters $U$ şeklinde bir açıklık bulunmaktadır. Portalin merkezinde bulunan kapı açıklığı basık kemerlidir. Taç kapı aralığının tymphanum kısmında kitâbe paneli bulunur. Kitabe paneli dikdörtgen çerçevelidir. 


\section{Mescit:}

Şu anda yapıda kesin olarak mescit olduğu tespit edilen herhangi bir mekân yoktur. Ancak bu büyüklükteki hanlarda mutlaka bir mescit bulunurdu. Bazı araştırmacılar avlunun gerisinde sağ tarafta yer alan kapalı mekânın mescit olarak kullanıldığı düşüncesindedirler. Bize göre mescit şu anda avlunun tam ortasında palmiye ağacının bulunduğu yerin üst kısmında bulunuyordu. $\mathrm{Bu}$ ağacın çevresinde ayak olarak kullanıldığı anlaşılan dört temel kalıntısı mevcuttur. Bazı hanlarda mescit kervansarayın tam ortasında bulunurdu. Burada da iki katlı bir mekânın olduğunu ve üst kısmının mescit olarak kullanıldığını söyleyebiliriz. Palmiye ağacının çevresindeki geniş ayak yerlerini başka türlü izah etmek neredeyse mümkün değildir.

\section{Restorasyon:}

Kırkgöz Han, 2007 yılında geniş kapsamlı bir restorasyon geçirmiştir. Restorasyon çerçevesinde kapalı bölümün üzeri betonla kaplanmış, dolayısıyla üst örtüye ait özgün unsurlar kaybolmuştur. Yapının kuzey cephesindeki dendanların bir kısmı orijinal halleriyle günümüze kadar ulaşmıştır. Restorasyon çalışmaları sırasında avluda kazı çalışmaları da gerçekleştirilmiş ve bir tandır bulunmuştur (Eravşar, 2017, s. 513). Restorasyondan sonra han fonksiyonel şekilde kullanılamamıştır.

Kırkgöz Han'la ilgili bazı resimler aşağıdadır:

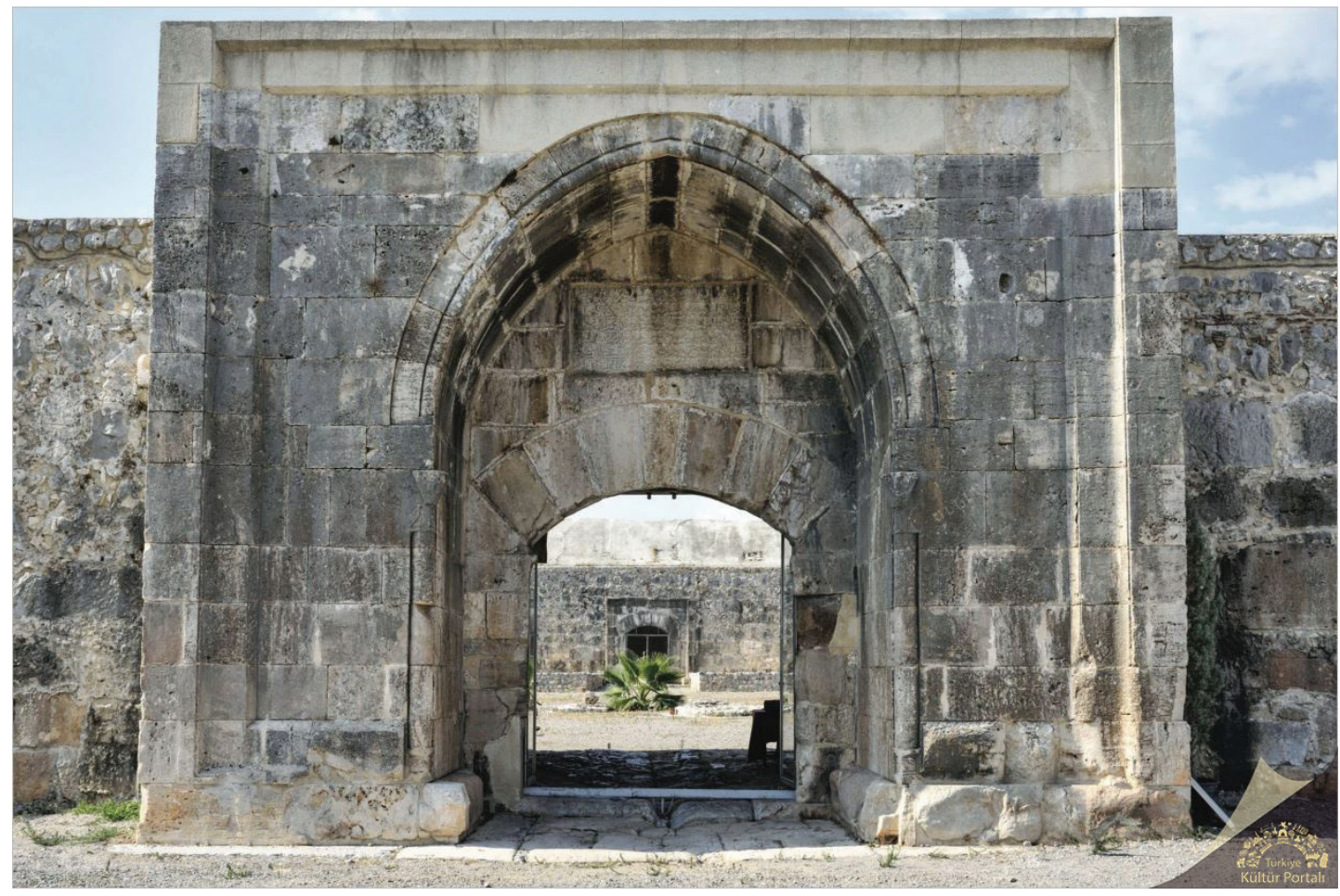

Resim 6. Restorasyondan sonra Kırkgöz Han'ın giriş kapısı

(Görsel sahibi: Konya Selçuklu Belediyesi) 


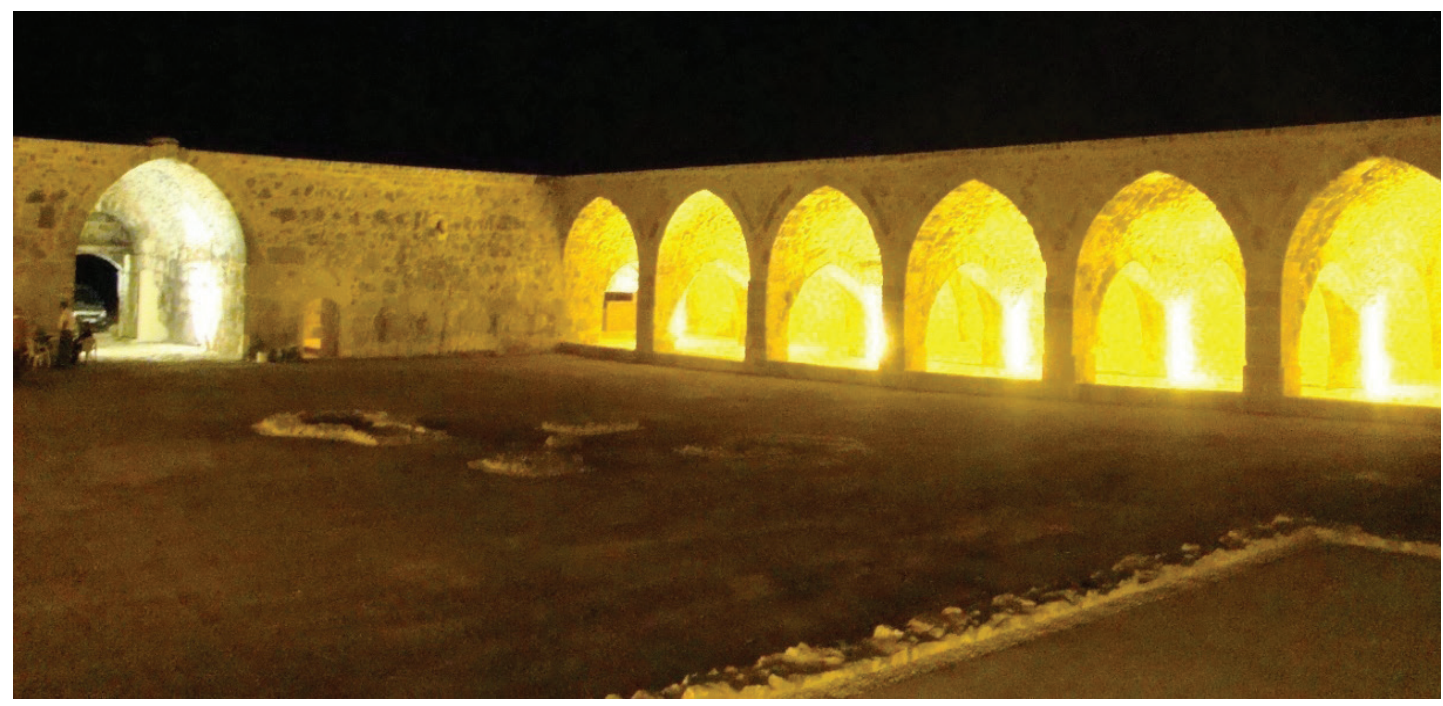

Resim 7. Restorasyondan önce Kırkgöz Han’ın içinden bir görüntü (nejaturegen.com)

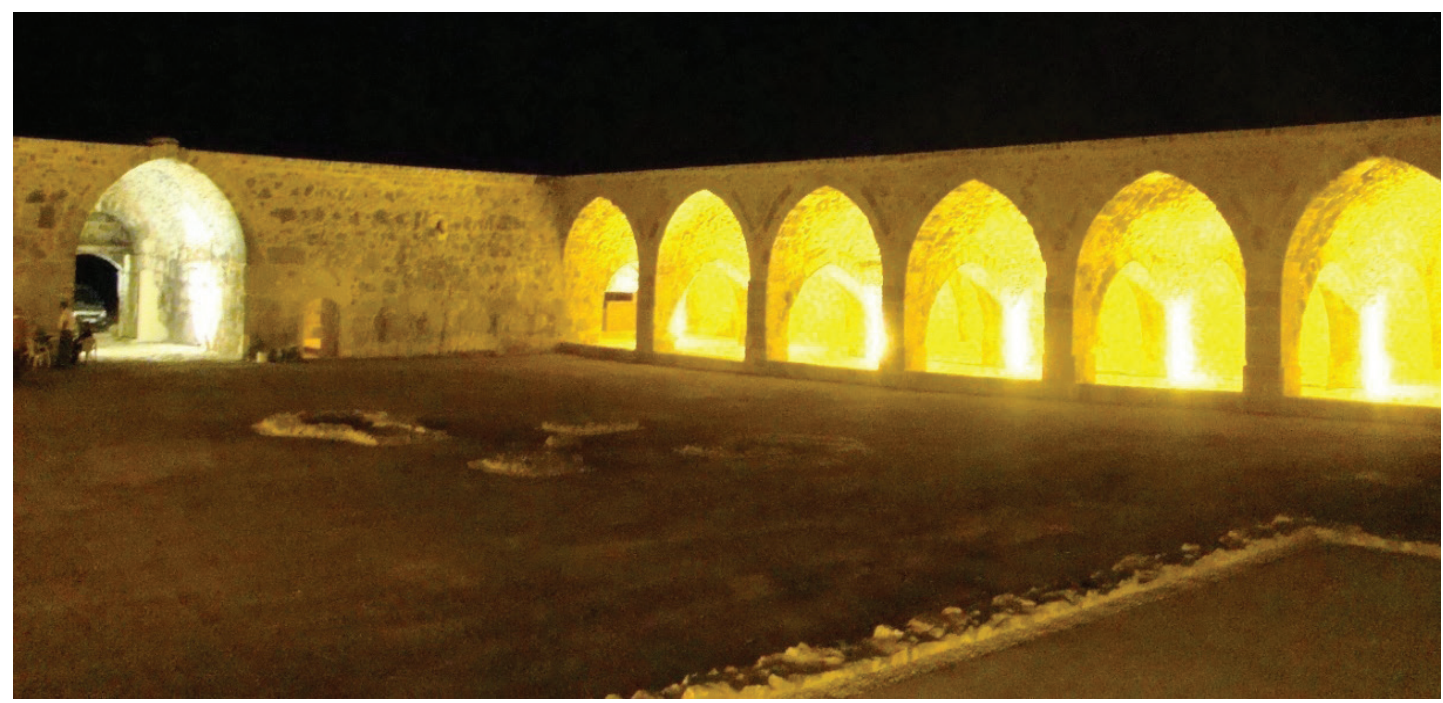

Resim 8: Restorasyondan sonra Kırkgöz Han’ın içinden bir görüntü (nejaturegen.com)

\subsubsection{Kırgız Hanı}

Antalya-Burdur yolu üzerindeki üçüncü menzil Kırgız Hanı'dır. Kırgız Hanı, I. Alâeddin Keykubad'ın oğlu II Keyhurev (1237-1246) döneminde yapılmıştır (Antalya hakkında). Kervansarayın Kırkgöz Han ile Burdur il sınırları içinde kalan ve Antalya'ya 75 km uzaklıkta yer alan Susuz Han arasında Dağbeli veya Bademağacı köyü civarında yer aldığını düşünmekteyiz. Zira iki han arasında en uygun yer burası görünmektedir. Çekül Vakfínın İpek Yolu Kültür Yolu Haritası'nda Kırgız Hanı'ndan söz edilmemekte ve tabii olarak haritada da yeri işaretlememiş olmaktadır. 


\subsubsection{Tibuk Hanı}

Antalya-Burdur istikametindeki dördüncü menzil Tibuk Hanı’dır.

Kiepert Haritalarında (1902-1906) Kırkgöz Han'dan sonra Tchibuk Hanı olarak geçen başka bir handan söz eder (Eravşar, 2017, s. 538). Çekül Vakfi'nın İpek Yolu Kültür Yolu Haritası'nda bu söz edilmemekte ve tabii olarak haritada da yeri işaretlememiş olmaktadır.

Burdur sınırları içinde kalan Susuz Han Antalya’ya ortalama 75 km, Kırkgöz Han ise 33 km mesafededir. İki han arasında ortalama 42 km'lik bir mesafe bulunmaktadır. Düz alanda bu mesafe tek yürüyüşle katedilebilir gibi görünmekle birlikte, arada yüksek dağların olması sebebiyle bu mümkün görünmemektedir. Bu sebeple iki han arasında mutlaka bir han bulunması gerekmektedir. Yeri tam olarak belli olmasa da bu güzergâh üzerinde iki ayrı hanın bulunduğunda söz edilmektedir. Ancak aradaki mesafe, iki hanı gerektirecek kadar uzun da değildir. Buna göre Kırgız Hanı ile Tibuk Hanı aynı hanın farklı isimleri olabilir. Çekül Vakfı'nın İpek Yolu Kültür Yolu Haritası'nda yeri işaretlenmemiştir.

Bundan sonra beşinci (veya dördüncü) menzil Burdur sınırları içindeki Susuz Han'dır.

\subsection{Antalya-Denizli Güzergâhındaki Kervansaraylar}

Antalya-Burdur güzergâhında olduğu gibi, Antalya-Denizli güzergâhının da ilk menzili Evdir Han’dır. Bundan sonra Denizli sınırına varıncaya kadar Korkuteli ve Elmalı ilçe sınırları içinde kalan kervansaraylar şunlardır:

\subsubsection{Güllik Hanı}

Evdir Han'dan sonra Antalya-Denizli güzergâhında ikinci menzil Güllik Hanı olabilir. Ritter, isim vermeden Evdir Han'dan bahsettikten sonra Güllik Han ismini taşıyan bir kervansaraydan söz eder (1858). Elmalı yolu üzerinde yer alan bu Han'ın nerede olduğunu bilmiyoruz (Eravşar, 2017, s. 538). Bize göre bu han, Korkuteli ilçesinin doğu kesiminde yer alan Güllük Dağı mevkiinde bulunmaklıdır. Kesin yerinin tespiti için bu alanda çalışma yapmak gerekir. Antalya-Elmalı yolunu kullanan (1842) seyyah Schöborn da yol üzerindeki hanlardan Güllik Hanı'nın ismini vermektedir (Eravşar, 2017, s. 538). Güllik Han'dan söz edenlerden birisi de, bölgenin tarihi ve coğrafyası hakkında bilgi veren (1862) Texier'dir (Eravşar, 2017, s. 539). Çekül Vakfı'nın İpek Yolu Kültür Yolu Haritası'nda adı zikredilmemiş ve yeri işaretlenmemiştir.

Güllik Han’ın, Antalya’ya 26 km uzaklıktaki Güllük Dağı eteklerinde olduğunu tahmin etmekteyiz. Adını da buradan almış olmalıdır. Çekül Vakfı'nın İpek Yolu Kültür Yolu Haritası'nda adı zikredilmemiş ve yeri işaretlenmemiştir. 


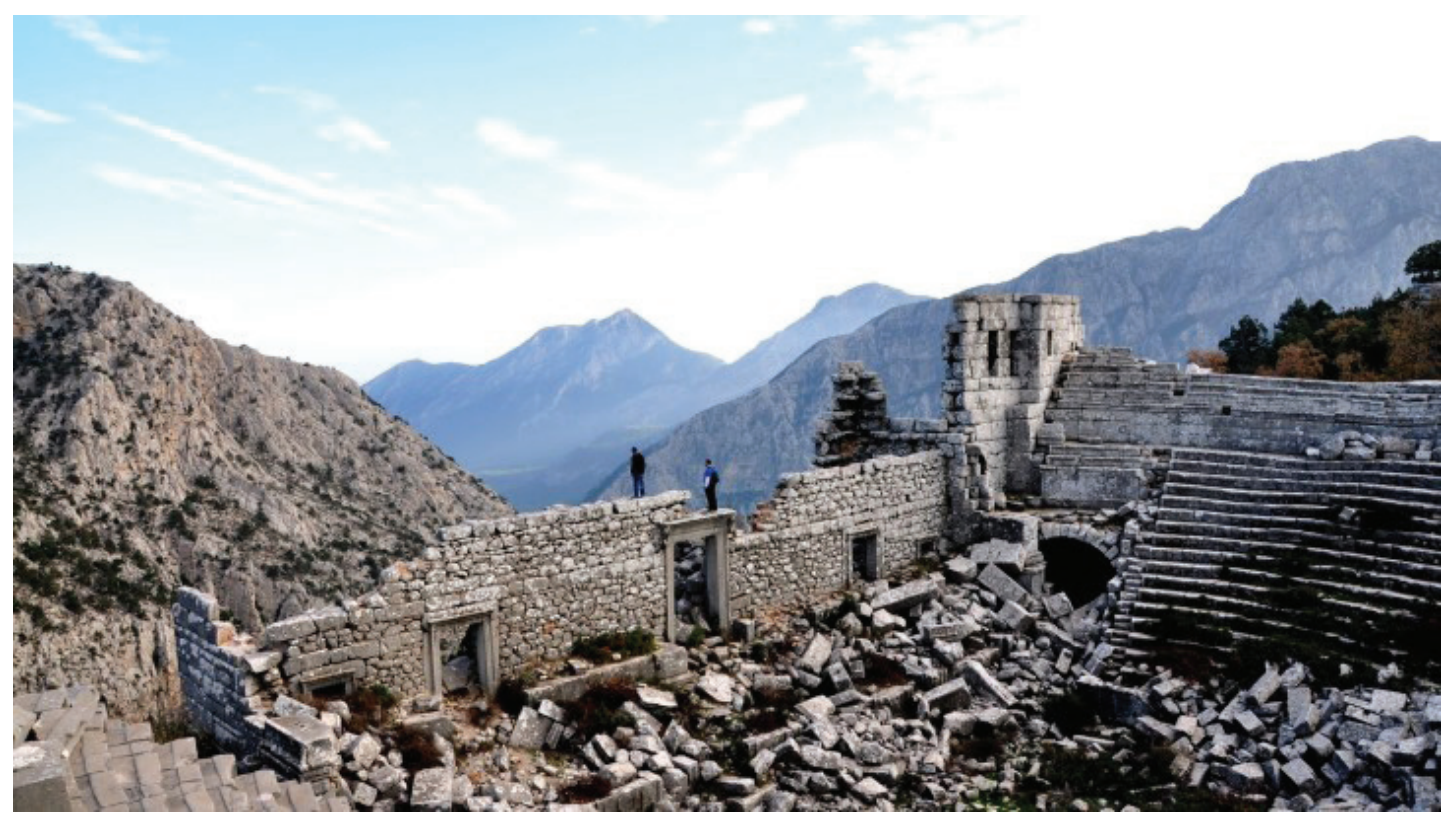

Resim 9: Güllük Dağ1 Antik Kentinden Bir Görüntü (geziantalya.com)

\subsubsection{Küçük Yenice Hanı (Korkuteli)}

Evdir Han'dan sonra üçüncü menzil Küçük Yenice Hanı olmalıdır. Küçük Yenice Hanı, Antalya-Korkuteli yolu üzerinde, Antalya'nın yaklaşık 30 km kuzeybatısında, Yenice Boğazı girişinde, Yenice Kahvesi adıyla anılan mahalde, yolun kuzey kenarında, yola yaklaşık yüz metre uzaklıkta bulunmaktadır. Küçük bir kesimi ayakta olan han, nerede ise tamamen yok olmak üzeredir. Sadece doğu, batı ve kuzey duvarlarının bir kısmı ayakta kalabilmiştir.

Kervansarayın kitabesi kayıp olduğu için ne zaman ve kimin tarafından inşa edildiği bilinmemektedir. Ancak plan ve bazı yapı özelliklerinden hareketle yaklaşık olarak bir tarih belirlemek mümkün görünmektedir. Bölgeyi ziyaret eden (1875) seyyahlardan Hirschfeld, Evdir Han'ın batısında yer alan Yenice Hanı'nı görmüş ve bu yapıyı tanımlamak için "Yenidsche Chan” ibaresini kullanmıştır (Eravşar, 2017, 539).

Küçük Yenice Hanı, Karaman-Mut kervan yolu üzerinde yer alan Kozak ve Sertavul, Kızı̈ören Hanı'nın 400 m kadar doğusunda bulunan han; Siirt-Eruh yolu üzerindeki Çemişevski Hanı; Ağın-Kemaliye yolu üzerindeki Arnavut Hanı; Kütahya-Afyon kervan yolu üzerindeki Döğer Hanı'ında olduğu gibi hemen tamamı 13.- 15. yüzyıllara tarihlenen Selçuklu döneminde inşa edilen iki sahınlı han örneklerine benzemektedir. Rahmi Hüseyin Ünal, bu benzerlikten hareketle kervansarayın 14 - 15. yüzyıllarda yapılmış olabileceği görüşündedir (Ünal, 2010, s. 60).

Evliya Çelebi 1671-72 yılında haccetmek için Mekke’ye giderken Yenice Hanı'na uğramış ve han hakkında şu bilgileri vermiştir: "Dâr-ı emândır (güvenli bir yapıdır). Adalya (Antalya) hâkinde (topră̆ında) bir yalçın kayalı dereli yerde üç kıt'a (parça) handır. Adalya ve İstınaz (Korkuteli) mâbeyninde (arasında) vâki 'olmuşdur (yer almaktadır). Âyende (gelen) vü (ve) revendeye (giden) ârâmgâhdır (dinlenme yeridir). Henüz binâ olunur. Ve bir kahvehânesi ve bir- 
kaç nev-binâ (yeni inşa edilmiş) dükkânları var. Ve Adalya kal 'asının dizdârı (kale muhafızı) Celeb Ca fer Ăga hânın mukâbelesinde (karşısında) nev-binâ bir çeşme-i âbı zülâl (berrak, saf suyu olan çeşme) inşâ iderken hakîrin (benim) bilbedâhe (irticalen söylediğim) bu tarihi celî hat (kalın ve iri harfli yazı) ile tahrîr olunmuşdur (yazılmıştır)... Sene 1078" (Evliya Çelebi, 2005, 9:145). 1078 yılı miladî 1667-68 yıllarına denk gelir.

Rahmi Hüseyin Ünal, Evliya Çelebi’nin verdiği bilgilerden hareketle (Küçük) Yenice Hanı'nın Anadolu Selçukluları döneminde yapılmış olabileceğini, bu hanın yakınında yapılmakta olan hanın ise Büyük Yenice Hanı olduğu düşüncesini dile getirmiştir. Evliya Çelebi’nin “üç kıt'a han" ifadesiyle de, Küçük Yenice Hanı, Büyük Yenice Hanı ve yeni inşâ edilmekte olan dükkânları kastettiğini ifade etmektedir (Ünal, 2010, s. 65). Buna göre harap halde olan Küçük Yenice Hanı Anadolu Selçukluları zamanında, Büyük Yenice Hanı ise Osmanlılar döneminde yapılmış olmaktadır.

Küçük Yenice Hanı’nın “kuzey duvarı, muhtemelen arazinin güneyden kuzeye doğru eğimli oluşu nedeniyle, yapının diğer duvarlarından daha yüksektir ve daha sağlam durumdadır. Doğu, batı ve kuzey duvarları üzerinde, bir girişe işaret edilebilecek herhangi bir iz seçilmemektedir. Bu durumda girişin, bugün tamamen ortadan kalkmış olan güney duvarı üzerinde yer aldığını düşünmek gerekmektedir. Yapının duvarları, düzgün derzler oluşturacak şekilde kırma taşlarla inşa edilmiştir. Kuzey duvarı, diğer duvarlardan daha yüksek olduğu için, dikdörtgen prizma şekilli beş adet payanda ile desteklenmiştir. Duvarların iç yüzeyinde dikkati çeken tek özellik, güney duvarının doğu yarısında yer alan dikdörtgen profilli niştir. Yapının içi moloz ve toprakla doludur. Hanın eni, içten içe 12 metreden fazladır. Boyu ise $31 \mathrm{~m}$ civarındadır. Çatısı, doğu-batı yönlü tonozlarla örtülü olmalıydı. $80 \mathrm{~cm}$. kalınlığındaki duvarların, 12 m’yi aşan bir açıklığa sahip tek bir tonozu taşıması zordur. Bu nedenle yapı, kuzey duvarı üzerindeki payandalardan ortadaki üçü hizasına yerleştirilmiş üç paye ile iki sahına bölünmüş olmalıydı. Payandaların çıkıntıları $1 \mathrm{~m} 75 \mathrm{~cm}$ ile $1 \mathrm{~m} 45 \mathrm{~cm}$ arasında değişmektedir. En doğudaki payandanın eni $1 \mathrm{~m} 40 \mathrm{~cm}$; diğer 4 payandanın enleri ise $1 \mathrm{~m}$. civarındadır. Payandalar arasındaki mesafe de, $5 \mathrm{~m} 40 \mathrm{~cm}$ ile $6 \mathrm{~m}$ arasında değişmektedir. Güney cephesinin batı ucunda, hanın batı duvarının güneye doğru devamı gibi algılanan bir duvar temeli, $4 \mathrm{~m} 50 \mathrm{~cm}$ kadar izlenebilmektedir. Bu duvar temeli, hanın güney cephesine bitişik bir sekinin kalıntısı olma11dır. Bir benzerine Tahtalı Beli Hanı'nda rastlanın bu seki, güney duvarı boyunca devam ediyor olmalıydı. İçte, güney duvarından $4 \mathrm{~m} 90 \mathrm{~cm}$ uzaklıkta, doğu-batı yönünde uzanan, aynı doğrultu üzerinde yer alan iki duvar kalıntısı dikkati çekmektedir. Biri batı duvarına, diğeri de doğu duvarına yakın olan bu iki temel kalıntısının kuzey yüzleri, açıkça algılanabilmektedir. $\mathrm{Bu}$ temeller, hanın kuzey duvarına yaslanan bir sekinin kalıntıları olmalıdır. Sekinin güney kenarına yerleştirildiğini düşünebileceğimiz dikdörtgen payeler hanı, yaklaşık eş genişlikte iki sahına bölmektedir. Böylece iki sahınlı bir ahırdan ibaret bir han şeması ile karşı karşıya olduğumuz anlaşılmaktadır." (Ünal, 2010, s. 59-60). Kervansayla ilgili resimler, Rahmi Hüseyin Ünal'ın 2010 y1lında Sanat Tarihi Dergisi'nde yayımlanan “Antalya-Korkuteli Kervan Yolu Üzerinde Bilinmeyen Üç Han” başlıklı makalesinde yer almaktadır. Çekül Vakfı'nın İpek Yolu Kültür Yolu Haritası'nda Küçük Yenice Hanı'nın ismi belirtilmemiş, yeri işaretlenmemiştir. 


\subsubsection{Bazar Hanı}

Antalya-Denizli güzergâhındaki dördüncü güzergâh Bazar Hanı olabilir. Bölgeye gelen (1816) seyyahlardan Corancez, adını vermeden Evdir Han’ın bazı özelliklerinden söz ederken, buradan kuzeybatıya doğru giderken Bazar Hanı diye bilinen bir yerleşkeden de bahseder. Burada iki caminin dışında harabeler de mevcuttur. Ancak bu harabelerin han mı yoksa başka yapılar mı olduğunu açıklamamıştır (Eravşar, 2017, 538). Bazar Hanı'nın adı Çekül Vakfi'nın İpek Yolu Kültür Yolu Haritası'nda zikredilmemiş ve yeri işaretlenmemiştir.

Corancez’in sözünü ettiği yerleşim yeri Yazır beldesi veya bu civardaki başka bir köy olabilir.

\subsubsection{Korkuteli Hanı}

Evliya Çelebi, Korkuteli'de Sultan Alaeddin tarafından yaptırılmış bir medrese, bir han, bir hamam, bir imaret bulunduğundan bahseder (Korkuteli Tarihi). Ancak burada sözü edilen han hakkında daha fazla bilgi sahibi değiliz. Osmanlılar zamanında da Kokuteli'de bir han vardı. Bu hanın Anadolu Selçukluları'ndan kalma o han olup olmadığı üzerinde araştırma yapmak gerekir. Çekül Vakfi'nın İpek Yolu Kültür Yolu Haritası'nda adı zikredilmemiş ve yeri işaretlenmemiştir.

\subsubsection{Tahtalı Beli Hanı}

Tahtalı Beli Antalya' merkeze yaklaşık 75 km uzaklıkta bir yerdir. Korkuteli- Elmalı arasında yer alan bir menzildir.

Tahtalı Beli Hanı, Antalya-Korkuteli karayolu üzerinde Tahtalı Beli mevkiinde yer almaktadır. Korkuteli yönünde yolun solunda, karayolu kotundan $10 \mathrm{~m}$. kadar aşağıda bulunmaktadır. Güneye doğru eğimli bir arazi üzerine kurulmuştur.

Diştan dışa $21 \mathrm{~m} 95 \mathrm{~cm}$ X $9 \mathrm{~m} 30 \mathrm{~cm}$ boyutlarındaki han, yaklaşık olarak 205 metrekarelik bir alanı kapsamaktadır. Yapı, "güneye doğru eğimli olan arazi tesviye edilerek oluşturulan düzlük üzerine inşa edilmiştir. Kuzeyindeki yara yaslandığı için kuzey duvarı sağırdır. Doğu ve batı duvarları nerede ise temel hizasına kadar" yıkılmış bulunmaktadır.

"Kitabesi olmadığı için ne zaman ve kimin tarafından inşa edildiği bilinmemektedir. Kalan izlerden hanın, tek sahınlı bir ahırdan ibaret, avlusuz hanlar grubundan olduğu anlaşılmaktadır. Dikdörtgen şekilli tek sahınlı bir şemaya sahip Anadolu hanlarının bir grubunda, giriş dar cepheye açılmıştır." Rahmi Hüseyin Ünal, oldukça harap durumdaki Tahtalı Beli Hanı’nın, ihtiyat kaydı ile 13.-14. yüzyıllara tarihlememin mümkün olduğu görüşündedir (Ünal, 2010, s. 71). Bu durumda yapı bir Selçuklu eseri olmaktadır.

Yine Rahmi Hüseyin Ünal yapının özelliklerini şu şekilde tasvir etmektedir: "Doğu ve batı duvarları yaklaşık aynı kalınlıktadır. Güney duvarı eğim nedeniyle oldukça yüksek inşa edilmiştir. Burada duvarının kalınlığ 1,1 m 50 cm'dir. Mekânı örten tonozun yükünü ve itme kuvvetini karşılamak durumundaki bu duvar, dıştan iki payanda ile desteklenmiştir. Güney duvarının doğu ve batı uçlarında küçük birer parça sağlam kalabilmiştir. Duvarın kalan kesimi, temel 
hizasına kadar tahrip olmuştur. Kuzey duvarı, kesintisiz izlenebilmektedir. Duvarlar, moloz taşlarla inşa edilmiştir. Köşelerde, irice blok taşlar kullanılmıştır. Yapının güneybatı köşesinden $4 \mathrm{~m} 75 \mathrm{~cm}$ uzaklıkta, güney duvarını destekleyen bir payandanın izi seçilebilmektedir. Güneydoğu köşesinden yaklaşık $6 \mathrm{~m} 50 \mathrm{~cm}$ uzaklıkta da, güney duvarına yaslandığını tahmin edilen bir merdivenden artakalan üç basamak görülmektedir. Muhtemelen çatıya çıkışı sağlayan ve kuzey duvarına bitişik olması gereken bu basamaklar, duvardan ayrılmış ve yan yatmış durumdadır. Batı duvarına bitişik bir temelin, güneye doğru $2 \mathrm{~m}$. kadar devam etmesi, Küçük Yenice Hanı'ndakine benzer şekilde güney duvarına bitişik bir dış sekinin varlığını düşündürmektedir. Yapının doğu ve batı kenarları üzerinde, giriş açıklığına ait herhangi bir iz yoktur. Kuzeydeki eğim nedeniyle sağır olan kuzey kenarı üzerinde de olamayacağı kesindir. Giriş açıklığı, muhtemelen güney kenarını ortalamaktaydı. Ancak, güney duvarının orta kesimi temel hizasına kadar tahrip olduğundan, bugün bu iddiayı destekleyecek hiçbir iz yoktur. Yapının içinde, molozlar ve yağmur suları ile sürüklenen toprağın, zemini hayli yükselttiği anlaşılmaktadır. Güney cephesinin batı ucunda yer alan, yaklaşık $2 \mathrm{~m} 50 \mathrm{~cm}$ yüksekliğindeki duvar parçasının iç kesiminde, yaklaşık $1 \mathrm{~m} 50 \mathrm{~cm}$ yükseklikten başlayan bir tonoz izi seçilebilmektedir. Doğu- batı yönünde uzanan bu tonozun $1 \mathrm{~m} 50 \mathrm{~cm}$ gibi oldukça düşük bir seviyeden başlaması, içteki zeminin hayli yükselmiş olduğunu düşündürmektedir." (Ünal, 2010, s. 79). Çekül Vakfı'nın İpek Yolu Kültür Yolu Haritası'nda yeri işaretlenmiştir.

\subsection{Antalya-Alanya-Anamur Güzergâhındaki Kervansaraylar}

Esasen Antalya ve Alanya'dan çıkan kervanlar Manavgat üzerinden Kubadabad veya Konya'ya giderlerdi. Ancak çalışmamız açısından sahil boyunda bulunan kervansarayları farklı bir güzergâh olarak ele aldık. Antalya'dan itibaren kervansaray sırası şöyledir:

\subsubsection{Köprüsuyu Hanı}

Antalya'dan çıkışta Alanya istikametine doğru birinci menzil Köprüsuyu Hanı'dır. Köprüsuyu Hanı, Antalya'nın doğusunda Aksu yolu üzerinde Köprüçay'ın sağ tarafında yer alan bir yapıdır. Çekül Vakfı'nın İpek Yolu Kültür Yolu Haritası'nda yeri işaretlenmiştir.

Köprüsuyu Hanı'nın dışında Antalya - Alanya karayolunun 44. km.sinden kuzeye dönen yolun 2. km.sinde Serik ilçesi Belkıs köyü sınırları içinde yer alan Aspendos Antik Kenti'nin tiyatrosunun da Selçuklular döneminde kervansaray olarak kullanıldığı anlaşılmaktadır. "Ünlü tiyatroda Selçuklu dönemi onarım izlerini, özellikle dış cephe ortasındaki anıtsal kapı eklentisinde ve cephesindeki koyu kırmızı zigzag desenli sıva kaplamada görmek mümkündür. Selçuklu sultanlarının konakladıkları, kervansaray olarak düzenlendiği düşünülen sahne binasının günümüze dek sağlam kalabilmesinin en önemli nedeninin de bu Selçuklu onarım ve korumac1lığına bağlanır” (Antalya İl Kültür Müdürlüğü).

\subsection{2. (Birinci) Pazarcık Hanı}

Antalya'dan çıkışta Alanya istikametine doğru ikinci menzil (Birinci) Pazarcık Hanı'dır. Manavgat ilçe sınırları dahilinde, kuzeyden güneye doğru Kargı Hanı'nın hizasında, denize olduk- 
ça yakın bir mevkide bulunmaktadır. Çekül Vakfı'nın İpek Yolu Kültür Yolu Haritası'nda yeri işaretlenmiştir.

\subsubsection{Alara Han (627/1230)}

Antalya'dan çıkışta Alanya istikametine doğru üçüncü menzil Alara Han'dır.

\section{Yeri:}

Alara Han, Antalya'nın 115 km. doğusunda Alanya'nın 37 km batısında, Manavgat'a 30 km mesafede Antalya-Alanya karayolunun takriben 104. kilometresinden sola ayrilan yolun 8 . kilometresinde, Akdeniz'e dökülen Alara çayının kenarında, Alara Kalesi'ne 800 m uzaktaki düzlükte, Okurcalar Beldesi Çakallar Köyü sınırları içinde yer alır.

Alara Han, eski Alanya-Konya kervan yolunun başlangıcında ikinci konaklama yeridir. Alanya istikametinde kendisinden önceki ilk kervansaray, Şerefza Han'dır. Alara Han'ın hemen önünde üç kemerli bir köprü yıkıntısı vardır. Alara'dan sonra yol kuzeye doğru yönelir. Ormanlık içindeki yol takib edilerek Ali Köprüsü’ndan geçilir ve Akseki'nin kuzeydoğusunda yer alan Rodar Hanı'na varılır. Ali Köprüsü'nün her iki yakasında Roma döneminden kalma taş döşeli yerin bazı kısımlarını sağlam olarak görmek mümkündür. Bu yol erken dönemlerden itibaren Akdeniz'i İç Anadolu'ya bağlamaktaydı. Alara Çayı ve çevresinin Bronz Çağı'ndan itibaren deniz ticaretinde bir iç liman olarak kullanıldığı tarihi belgelerle sabittir.

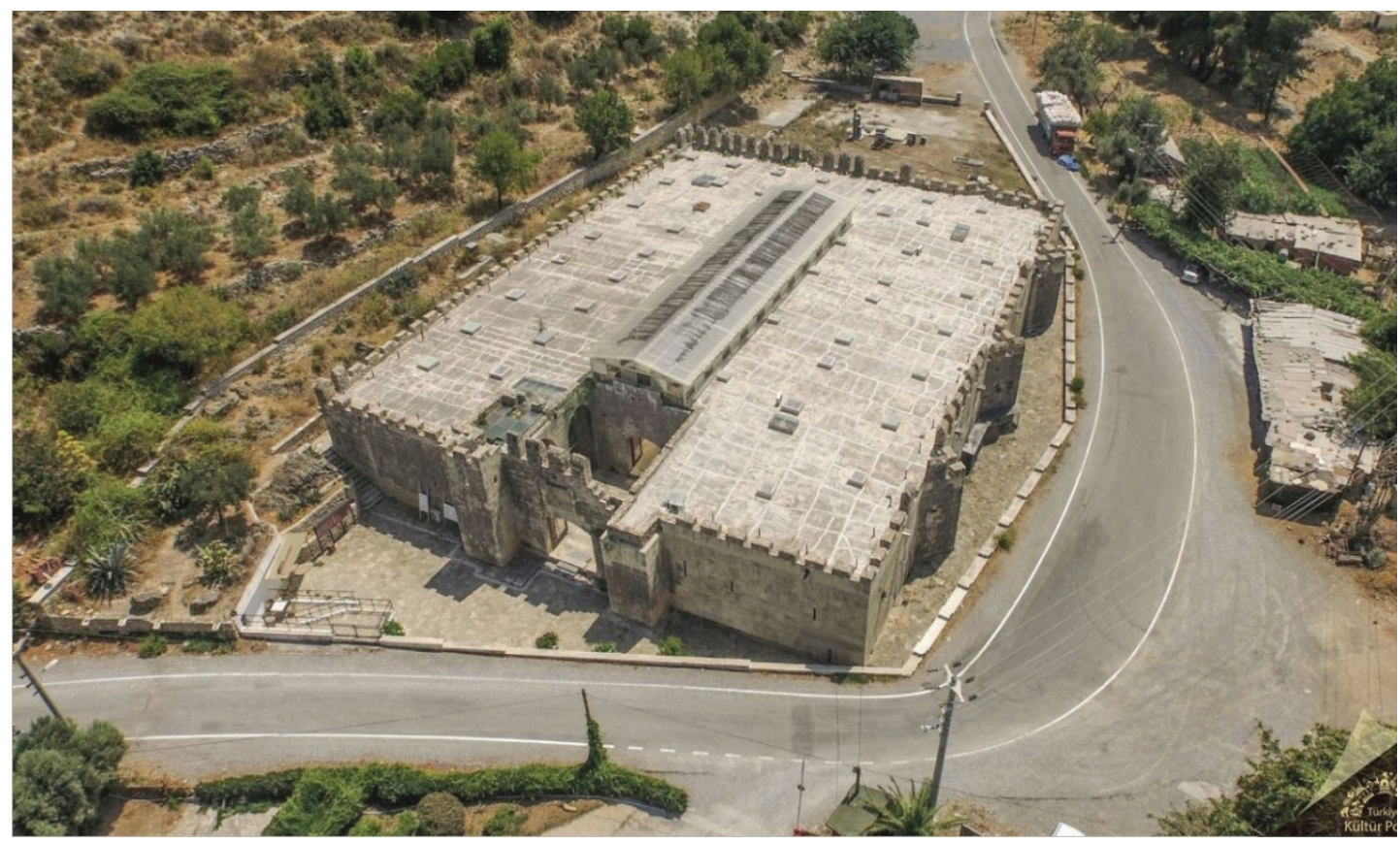

Resim 10: Alara Han'ın havadan görünüşü (https://www.kulturportali.gov.tr) 


\section{Kitâbesi, bânisi ve inșâ tarihi:}

Giriş cephesindeki iki kule arasında büyük sivri kemerli niş içine alınmış cümle kapısı bulunmaktadır. Kapı kemeri üzerindeki dolgu içine üst kısmı yuvarlak kemer şeklinde altı satırlık kitabe taşı konulmuştur. Kitâbenin üzerinde ve yuvarlak kemerle çevrelenen alandaki boşluk, kitâbenin üst kısmının zamanla ortadan kalkmış olduğunu göstermektedir. Kitâbenin birinci satırı bu kısımda yer aldığı ve zamanla kırılıp ortadan kalktığ1 için burada ne yazıldığ rak bilinmemektedir. Ancak Ali Yardım, I. Alaaddin Keykubad dönemindeki Alanya kitabelerinin üst kısmındaki kemerli bölümde en başta "el-minneti lillâh: minnet Allah'dır” şeklinde "yazılı olduğu için burada aynı ibarenin bulunması gerektiği kanaatindedir. Bu ifadenin devamında da "Emera bi-imâreti hâzâ'l-hân el-Mübârek es-Sultân: Bu mübarek hanın yapilmasını Yüce Sultan emretti” ifadesi yazılmış olmalıdır (Yardım, 2002, s. 437). Kitâbenin geri kalan kısmında şunlar yazılmıştır: “... el-A'zam, şehin-şâhi'l-muazzam, mâlik-i rikâbi'l-ümem, seyyid-i selâtîni'l-Arab ve'l-Acem, sultân-1 hak ve şâh-1 vesâ-yı cihân, sultâni'l-berr ve'l-bahr ve'r-Rûm ve'ş-Şâm ve'l-Armen ve'l-Frenc, Alâu'd-dünya ve'd-din Keykûbâd bin Keyhusrev bin K1liç Arslan, Burhân-1 emîri'l-mü'minîn fi et-târîh sene tis'a ve '1şrîne ve seb 'a-mi’e 627 h. (1230).”

Kitabenin Türkçesi şöyledir: “... En büyük (sultan), Sultanların büyük sultanı, milletlerin hakimiyetlerini elinde tutan, gerçek sultan, Arap ve Acem sultanlarının efendisi, ülkeler fetheden, karanın ve denizin, Rum'un, Şam’ın, Ermenistan'ın ve Freng'in hükümdarı, din ve dünyasını ulusu, emîru'l-mü'minînin bürhanı Kılıç Arslan oğlu Keybûbâd Tarih sene: 627 (1230) yılında (emretti)."

Kuzey-doğu cephesindeki basık kemerli kapı açıklı̆̆ının üzerine yerleştirilmiş altı satırlık kitâbesinde 629 H. (1231) yılında I. Alaaddin Keykubad tarafından yaptırıldığı yazılmaktadır.

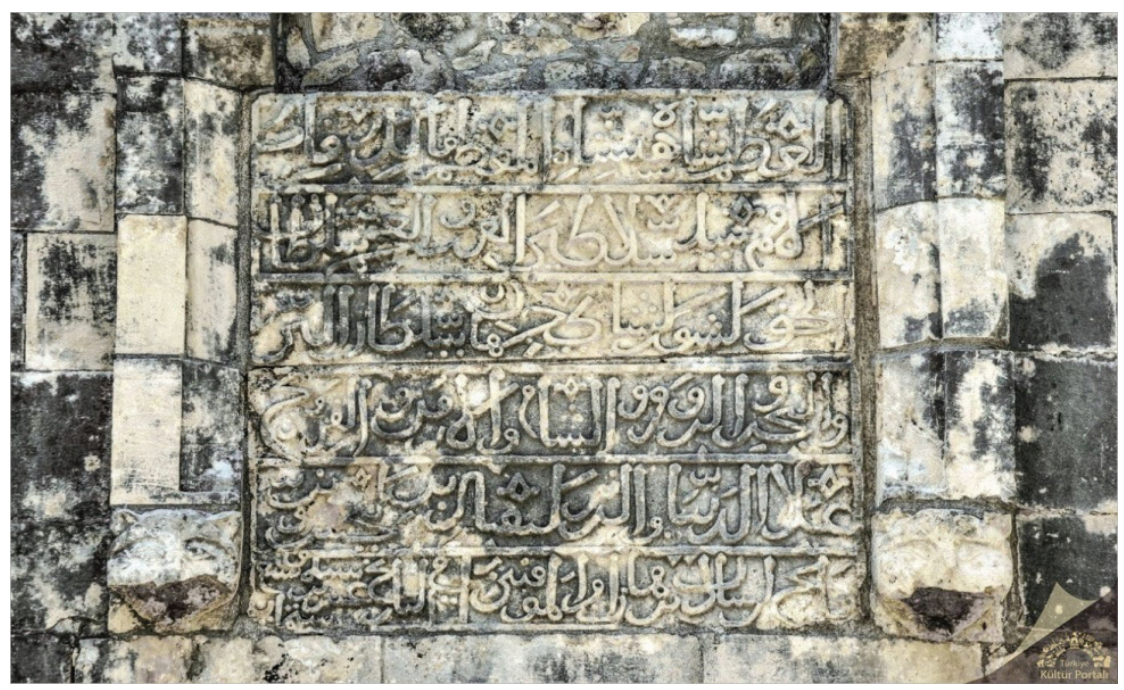

Resim 11: Alara Han'1n Kitâbesi (https://www.kulturportali.gov.tr) 


\section{Planı ve yapı özellikleri:}

Alara Han bizzat sultan tarafından yaptırıldığ 1 için "sultan hanları"ndan sayılmakla beraber planı itibariyle onlardan çok farklı bir özelliğe sahiptir. Kuzey-güney doğrultusunda yerleştirilmiş olan han, Anadolu Selçuklu han mimarisinde konsantrik planlı veya eş odaklı hanlar kategorisinde değerlendirilir.

Sultan hanlarının plan şemasında genellikle açık avlu ve kapalı hol bölümleri bulunurdu. Alara Han’da bir istisnaya gidilip dikdörtgen şeklindeki bir plan içinde, kapalı bölüm ile açık avlu fonksiyonları tek merkez etrafında iç içe olmak üzere tasarlanmıştır. Anadolu kervansarayları arasında Afşin ve Tercan kervansarayları da benzer bir plan şemasına sahiptir. Bu üç kervansaray plan şeması bakımından ayrı bir grup oluşturmaktadır. Alara Han, bu grubun en önemli örneği olarak günümüze ulaşma başarısını gösterebilmiştir. Bir görüşe göre Alara Han'ın değişik planda yapılmasının sebebi, özellikle Alâeddin Keykubad'ın Alanya yolculukları sırasında yanındakilerle birlikte burada dinlenmesi için inşa edilmiş olmasıdır (Altun, 1989, s. 2/341).

Sultanın bu kervansarayı, Alanya-Antalya ya da Konya güzergâhlarındaki seyahatleri sırasında ordusunun konaklaması amacıyla ribat olarak inşa ettiği düşünülmektedir. Kapalı avlulu hanlar grubu içinde yer alan Alara Han'ın inşa stilinde sıradışı bir plan uygulanmış; dar ve uzun avluya açılan mekânlar ahır bölümüyle çepeçevre kuşatılmıştır (Akalın, 2002 s. 302). Yapı bütünüyle simetrik bir plana sahiptir. Üç tarafı açık olan hanın doğusu bir tepeye yaslanmış olup moloz taştan örülmüştür. Diğer üç cephesi kesme taş kaplıdır. Üst örtü toprak damdır. Girişin iki yanındaki kulelerden biri yıkılmış durumdadır (Antalya İl Kültür Müdürlüğü, 2012, s. 288).

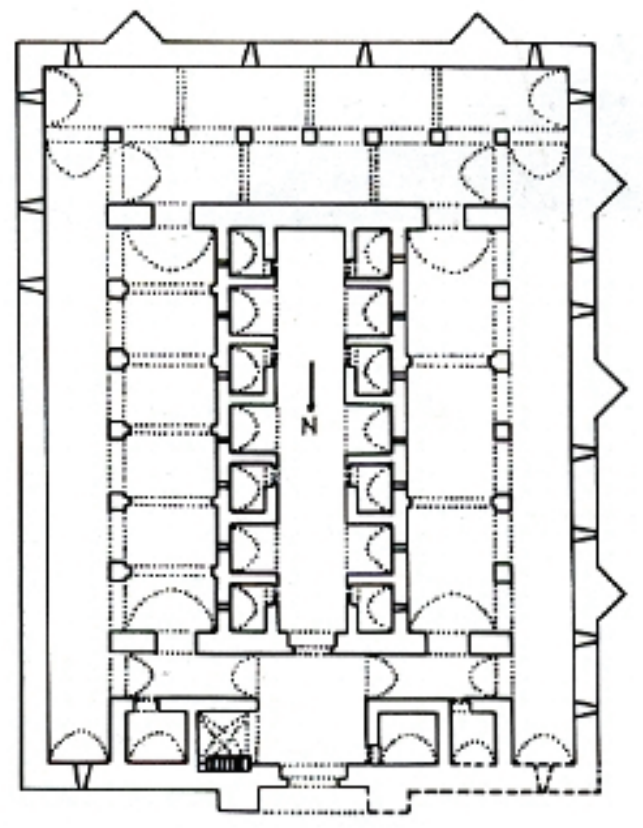


Tamamı 34.5 x 45 metre ebadında büyük bir dikdörtgen teşkil eden han, yaklaşık 1600 metrekarelik bir alanı işgal etmektedir. Beden duvarları, girişe göre sağ yan cephe üç, karşı cephe ise iki adet üçgen payanda ile takviye edilmiştir. Muntazam dikdörtgen planlı hanın giriş cephesi ayrı bir özellik taşımakta, iç plan taksimatı diğer Selçuklu hanlarından ayrılmaktadır (Portfolio Alara Han). Cümle kapısının iki yanında çıkıntı teşkil eden kare kulelerle kervansaray, ufak bir kale hüviyetini kazanmı̧̧ görünmektedir. Tamamen kesme taştan inşa edilmiş olan beden duvarları çok sağlam ve kuvvetlidir.

Alara Han hakkında bilgiler şöyledir: Han, kuzey-doğu güney-batı yönünde uzanan dikdörtgen planlı bir oturum alanına sahiptir. Ana cephe haricindeki kuzey-batı ve güney-batı cephelerinde, belirli aralıklarla yerleştirilmiş ve cephe kotuna kadar yükselen üçgen prizmal formlu payandalar bulunur; güney-doğu cephesi, bu yönde yükselen toprak tepenin yamacına yakın olarak inşa edildiği için, bir istinad duvarı işlevi görmek üzere kaba yonu ve moloz taşlarla örülmüştür. Yapının saçak kotunda yükselen dendanlar, payandalar da dahil olmak üzere, mazgal dişleri halinde bütün çatıyı takip ederek dolaşır (Gezilecek Yerler Alara Han).

Hanın giriş bölümü, kare planlı küçük bir avlu şeklinde tasarlanmıştır. Doğu kanadında, sivri kemer gözü halinde avluya açılan yarı açık mekân, yıldız tonozla örtülü çeşme eyvanıdır. Doğu duvarında, yekpâre taştan oyma istiridye formlu kavsarayla örtülü dikdörtgen bir niş halinde çeşme yer alır. Nişin alt kenarında, yekpâre taştan oyulmuş bir su haznesi bulunmaktadır. Çeşmenin ön yüzünde iki lüle deliği mevcuttur. Altta, iki yandan eyvan sekisini oluşturan iki blok taş arasına yerleştirilmiş ve geçmişte muhtemelen yekpâre taştan oyulmuş dikdörtgen bir yalak bulunduğu anlaşılmaktadır. Lüle deliklerinin etrafındaki kalıntıların durumuna bakılarak, geçmişte birer arslan başı konsol şeklinde tasarlanmış olabilecekleri düşünülmektedir. Çeşme eyvanının döşemesi, sekiler ve çeşme yalağı, define arayıcılar tarafından tahrip edilmiştir. Çeşme eyvanının kuzey duvarındaki yedi basamaklı bir taş merdivenle, hanın girişini kontrol eden doğu kanattaki kuleye ve çatıya çıkılmaktadır. Mevcut izlere bakılırsa, bu kuleden de, giriş bölümündeki küçük avlunun kuzey kanadını oluşturan cephe duvarının üzerindeki çatıya bir seğirdim vasıtasıyla ulaşılabilmekteydi. Avlunun doğu ucundaki sivri beşik tonoz örtülü bir oda ile batı kanadına bitişik iki oda yer almaktadır. Batı kanadına bitişik sivri beşik tonoz örtülü ilk oda mescittir; diğer iki odanın servis mekânları olarak işlev gördüğü ileri sürülmüştür (Gezilecek Yerler Alara Han).

Avlunun güney kanadındaki basık kemerli bir kapı açıklığıyla, handa konaklayanlara tahsis edilmiş ve merkezini kuzey-doğu güney-batı doğrultusunda derinlemesine uzanan bir koridor ile karşılıklı olarak yerleştirilmiş oda ve eyvanlardan oluşan bir plan düzenlemesi halinde koridora açılan yarı-açık ve kapalı mekânların bulunduğu orta bölüme girilmektedir. Koridorun uzun kenarı üzerindeki bu farklı mekânsal düzenlemenin, odaların gün içindeki işlevleriyle ilişkili olduğu düşünülmektedir. Sivri beşik tonozla örtülü mekânların açıldığ1 ve hâlihazırda üzeri demir konstrüksiyon ve polikarbon bir çatıyla kapatılmış açık bir avlu görünümündeki koridorun, geçmişte sivri beşik tonozla örtülü olduğu anlaşılmaktadır (Gezilecek Yerler Alara Han).

Hanın orta bölümünü, kuzey-doğu kanadı üzerinde yer alan ve giriş bölümünü oluşturan avlunun doğu ve batı kanatlarındaki sivri beşik tonoz örtülü birer koridorla irtibatlanan çift sıralı 
bir galeri üç yönden çepeçevre dolaşmaktadır. Sivri beşik tonozla örtülü ve orta bölüme bitişik olarak kuzey-doğu güney-batı yönünde uzanan iki galerinin, geçmişte, handa konaklayanların ve hizmetkârların dinlenmesi kadar, kervan yüklerinin indirilmesi için de kullanıldığı; dış kenarlar boyunca uzanan diğer galerilerin de ahır işlevi gördüğü tahmin edilmektedir. (Gezilecek Yerler Alara Han).

Galerilerin kemer ayaklarına yerleştirilmiş arslan başlı taş konsollar, hanın aydınlatmasını sağlayan kandillerin konulması için yapılmıştır. Hanın inşaatında kullanılan düzgün kesme taşların bazılarında grafiti olarak taşçı işaretlerine rastlandığı gibi, duvar örgüsü arasında sıva üzerine yapılmış kırmızı boyalı zikzak desenlerine de tesadüf edilmektedir (Gezilecek Yerler Alara Han).

Eş odaklı plan tarzında inşa edilmiş olan Alara Han'ın orta kısmı handa konaklayan misafirlere ayrılmıştır. Yolcularla hayvanların konakladığı yerler ayrı ayrıdır. Yolcuların kaldığı mekânlar ile oturdukları eyvanların duvarlarında pencereler mevcuttur. Hanın içi oldukça karanlıktır. Aydınlatma dış duvarlardaki dar ve uzun pencerelerden sağlanmaktadır.

\section{Taçkapısı:}

Osman Evravşar taçkapısı hakkında şu bilgiyi veriyor: "Yapının taç kapısı, kuzey cephe duvar1nı ortalayacak şekilde konumlandırılmıştır. Her iki yanında koruma kuleleri yer alır. Kare kesitli kulelerden birisi üst örtü seviyesinde; diğeri yarısına kadar sağlam olarak durmaktadır. Daha sağlam olan doğudaki kulenin üzerinde iki mazgal pencere boşluğu görülmektedir. Kapı açıklığı basık kemerlidir. Basık kemerin üzengi taşları, silmeli profil şeklinde çıkıntı yapmaktadır. Üzengi taşının üzerindeki ilk taş, kare kilit şeklinde üzengi taşına bağlanmıştır. Kapı kemerinin üstünde kare bir kitabe ve bunun üstünde de kemerlik, boş bir kitabe panosu yer almaktadır. İki parçadan oluştuğu anlaşılan kitabenin üstteki kısmı kayıp olup bugün yeri boş durmaktadır. Kitabe, iki yanda, altta aslan başlı iki konsola binen bir çerçeve içine alınmıştır. Çerçeve yukarıda bağlantı yapmadan sonlanmaktadır. Taç kapının batı tarafındaki kısım tamamlanmadan bırakılmıştır” (Eravşar, 2017, s. 527).

\section{Mescit:}

Alara Han'da mescit, Obruk Han ve Sarı Han'da olduğu gibi giriş eyvanının üzerinde yer almaktadır (Aytaç). Girişin iki yanındaki kulelerden biri yıkılmış durumdadır. Soldakinin üst katında merdivenle çıkılan bir odacık bulunmaktadır. Burası mescittir (Antalya İ1 Kültür ve Turizm Müdürlüğü, 2012: 288).

\section{Süsleme:}

Alara Han'da sade süsleme unsurları tercih edilmiştir. Taşların çoğunun yüzeylerinde geometrik çizgiler veya şekillerden meydana gelen taş̧̧ı işaretleri ve damgaları bulunmaktadır. Han'ın taç kapısında yer alan kitabe çerçevesinin oturduğu konsollar arslan başı şeklindedir. İç mekânda, konsol biçimindeki dikdörtgen şekilli kandillerin birer yüzeyi kabartma tekniğinde yapılmış, insan ifadeli, sevimli, stilize aslan başı şeklindedir. Çeşme eyvanının yıldız tonozunda sadece örtme amacı güdülmemiş, süslemeye de büyük önem verilmiştir. Tonozun merkezinde yer alan ortası delik sekizgen biçimli kilit taşının delik olan kısmının etrafına işlenmiş on altı kollu yıl- 
dız motifi vardır. Yine eyvanın, beş dilimli istiridye kavsaralı çeşme nişi, merdiven basamaklarının güney yüzlerindeki mukarnas dolgular ve merdivenin yedi basamağının bitti seviyede ters mukarnas doluğu ve bunun üzerinde motifinden başka Han'da herhangi bir süsleme unsuruna rastlanmamaktadır (Erdoğdu, 2018, s. 14).

\section{Restorasyon:}

Restore edilen eser ziyarete açık olup aynı zamanda restaurant olarak kullanılmaktadır.

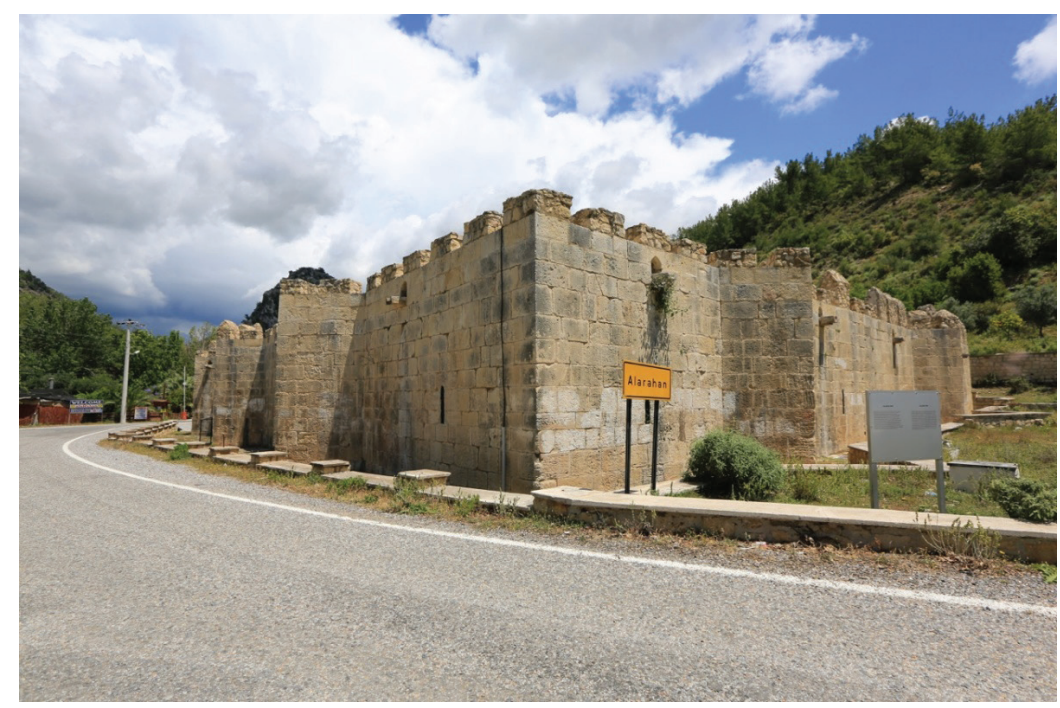

Resim 12: Alara Han'ın dışarıdan görünüşü (Antalya Gezi Rehberi)

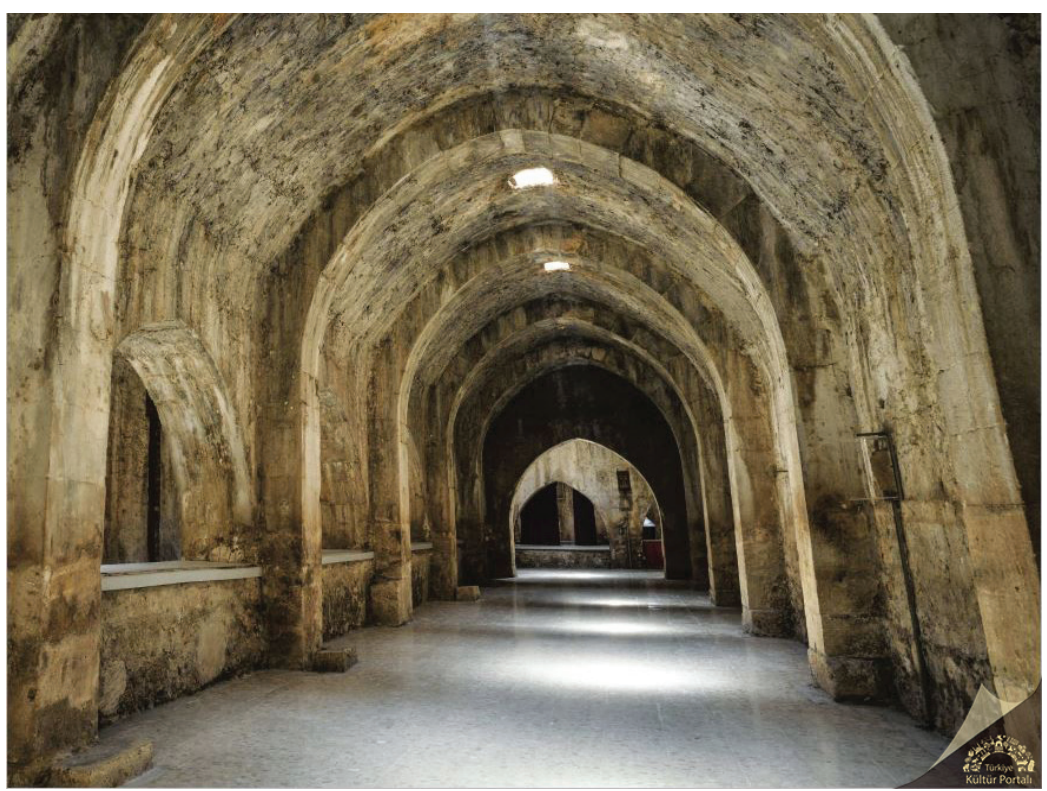

Resim 13: Alara Han'ın içinden bir görüntü (kulturportali.gov.tr) 


\subsection{4. Șarapsa Han (1236-1246)}

Antalya'dan çıktıktan sonra Alanya istikametine doğru dördüncü menzil Şarapsa Hanı’dır.

\section{Yeri:}

Asıl adı Şerefza Hanı olan, genellikle Şarapsa Han olarak bilinen kervansarayın adı bazı yayınlarda Şarafsa Han olarak geçer. Kervansaray, Alanya’nın 15 km batısında, Alanya-Antalya karayolu üzerindeki Konaklı Köyü sınırları içinde, küçük bir tepe üzerinde yer almaktadır.

\section{Kitâbesi, bânisi ve inșa tarihi:}

Kervansarayın taçkapısı üzerinde beyaz mermer üzerine yazılmış beş satırlık Arapça bir kitâbesi mevcuttur. Kitâbede şunlar yazılıdır: "es-Sultanü'l-A'zam, Şehinşâh el-Muazzam, Zillullâh fi'l-âlemîn, Giyâsü'd-dünya ve'd-dîn Ebü'l-Feth Keyhusrev bin Keykûbâd, (kazınmış). Türkçesi şöyledir: En büyük sultan, Şahların büyük şahı, Dünyada Allah'ın gölgesi, Din ve dünyanın yardımcısı, Fethin babası, Keykûbad oğlu Keyhusrev..." Kitabede inşa tarihi kazınmış olmakla birlikte Şarapsa Hanı'nın Selçuklu Sultanı II. Gıyâseddin Keyhüsrev (12371246) döneminde inşa edildiği anlaşılmaktadır.

Şarapsa Han'ın, mescidin taçkapısı üzerinde Arapça iki satır halinde nesih hatla yazılmış ikinci bir kitabesi daha bulunmaktadır. Kitâbede Tevbe suresi 18. âyetin ilk kısmı yazılıdır: "İnnemâ ya 'muru mesâcide'llâhi men âmene billâhi ve'l-yevmi'l-âhiri.” Türkçesi: Allah'ın mescitlerini ancak Allah'a ve âhiret gününe iman edenler imar ederler" (Eravşar, 1917, s. 87).

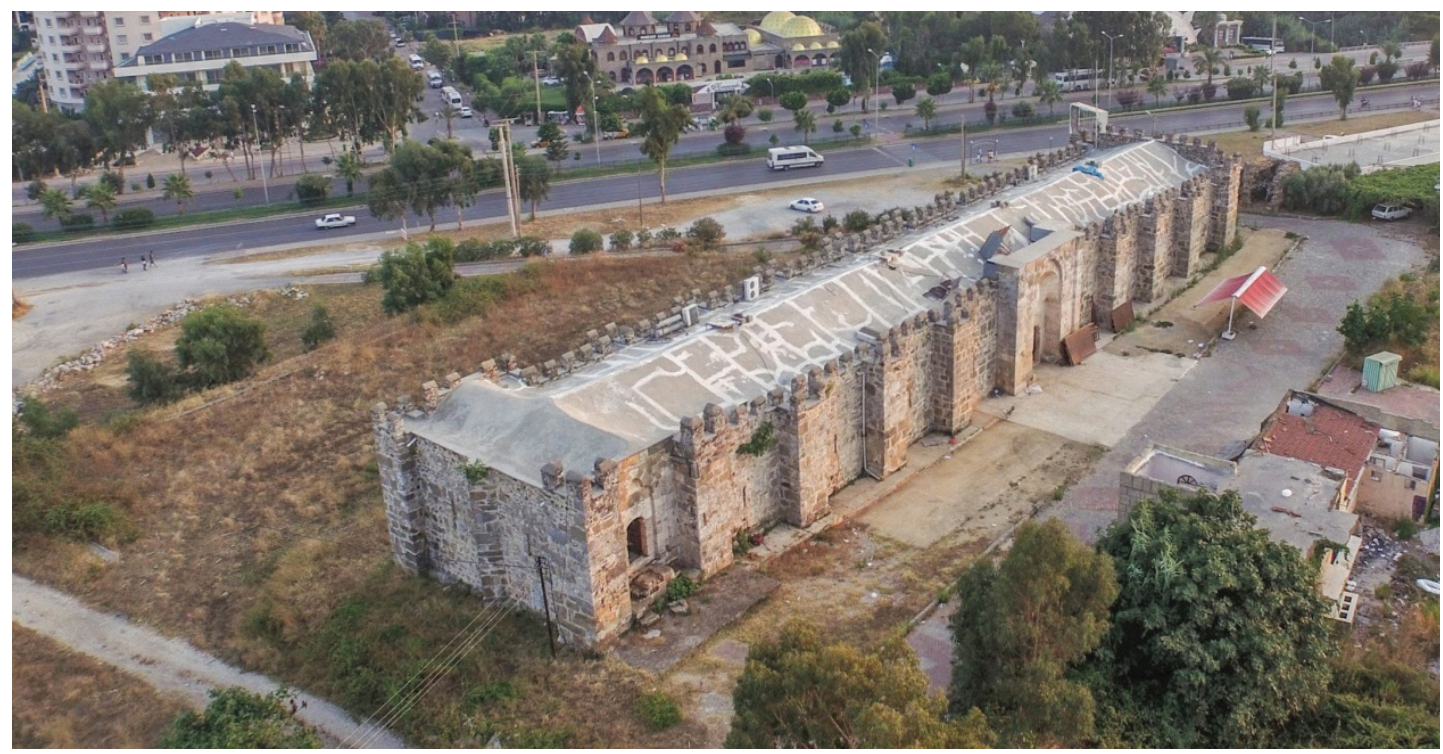

Resim 14: Şarapsa Han’ın havadan görünüşü (selcuklumimarisi.com) 


\section{Kervansarayın önemi:}

Şarapsa Hanı, Konya'dan çıkan kervanların en kısa yoldan Alanya ve Antalya’ya ulaşmasını sağlayan güzergâh üzerinde bulunmaktadır. "Konya'dan çıkan kervanlar Kuruçeşme ve Kızılören hanları gibi hala ayakta olan yapıları geçtikten sonra, Yunuslar ile Küçük Avşar köyünden Seydişehir Yeniceköy'deki Çiftlik Han'a ve oradan da Derebucak Tol Han'a gelirler. Kubâdâbâd Sarayı'ndan çıkan kervanlar iki yol takip ederler. Birincisi güneyden Torosları aşarak Ebu'l Hasan ve Burma Han üzerinden Karg1 Han ile Antalya'ya; diğeri ise doğu yönünde Derebucak Tol Han'ından Beyşehir üzeri gelen Çiftlik Hanı yolu ile birleşerek Ortapoyam, Eynif Tol ve Murt Beli Hanı'na ulaşmaktadırlar. Murt Beli Hanı'nda yol güzergâhı tekrar ikiye ayrılarak Karg1 Han'dan Antalya, diğer yandan da Alara ve Şarapsa hanlarıly Alanya şehirlerine varırlar. Anadolu Selçuklu dönemi menzil hanları tipolojisine uygun olarak çeşitlenen Derebucak Tol, Ortapoyam ve Şarapsa Han, Kargıhan, Eynif Tol ve Alara hanları ile Altınapa, Kuruçeşme, Kızı̈ören, Yenice-Çiftlik ve Murt Beli Han’ı gibi yapıların bu güzergâhta yapılmış olması Selçuklu devletinin bölgeye verdiği önemi ortaya koymaktadır” (Kunduracı, 2011, s. 192).

\section{Planı ve yapı özellikleri:}

Şarapsa Hanı, sadece barınak kısımdan oluşan tek sahınlı kapalı hanlar sınıfına girmektedir (Eravşar, 2017, s. 80). "Doğu-batı doğrultusunda uzanan dikdörtgen planlı tek bir mekân halinde inşa edilmiştir. Yapının kuzey ve güney cepheleri birbirine eşit aralıklarla dizilen ve çatı seviyesine kadar yükselen dikdörtgen prizmal payandalarla desteklenmiştir. Hanı çevreleyen dendanlar yapıya dıştan bir kale görünümü vermektedir. Barınak bölümünün üzeri sivri beşik tonoz ile örtülüdür. Kervansarayın güney duvarının ortasında kesme taş örgülü bir de mihrabı bulunmaktadır." Derebucak Tol Hanı ile Şarapsa Han arasında plan benzerliğinin ötesinde yapısal benzerlikler de vardır. Göze çarpan benzerlik, her iki hanın aynı kişi tarafından aynı mimara yaptırılmı̧̧ olduğu izlemini vermektedir (Kunduracı, 2011, s. 191).

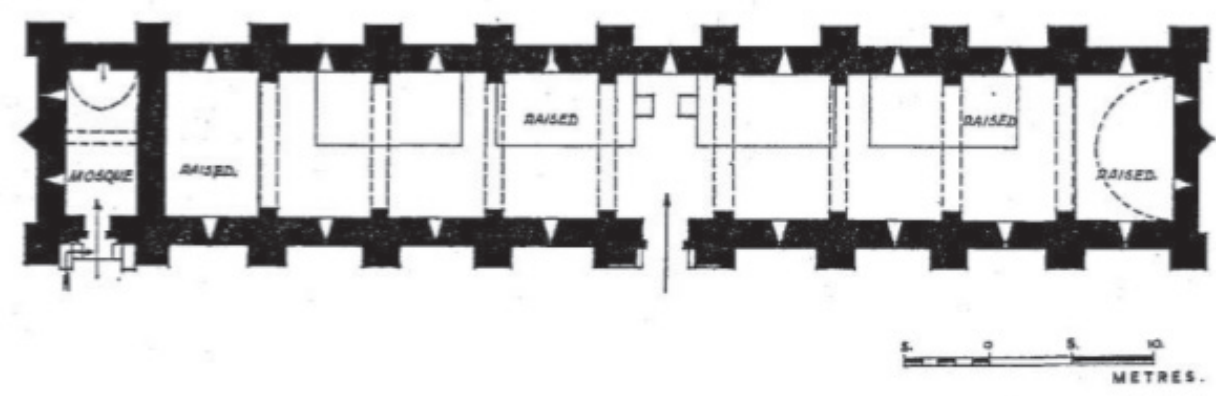

Şerefza Han, Plan (Lloyd ve rice, 1958: 46, Fig.22) 


\section{Taç kapı:}

Taç kapı, kervansarayın kuzey cephesinin ortasında yer almaktadır. Taşıyıcı duvarlardan öne doğru taşırılmış vaziyettedir. Taç kapı kompozisyonu, iki merkezli kemer etrafina oturtulmuştur. Taç kapı açıklığını düz profilli silmeler çevreler ve bu silmeler kapının seki kısmına bağlanır. Taç kapı açıklığının içinde küremsi örtülü bir kısım bulunur. Bunun üzerinde tepesi kemerli, yanları dikdörtgen taşlarla çevrili bir kitabe paneli bulunur. Kitabenin ortaladığı alttaki kapının basık kemerleri yanlardaki profilli konsollara oturtulmuş bulunmaktadır (Eravşar, 2017, s. 94).

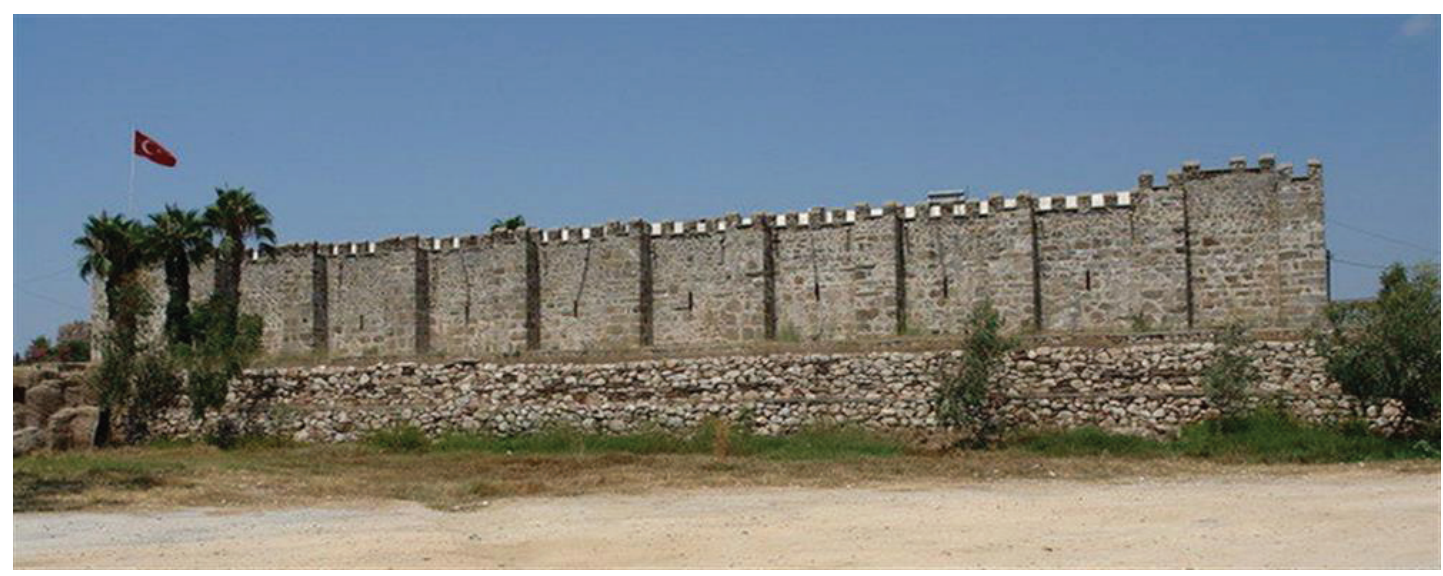

Resim 15: Şarapsa Han’ın dişarıdan görüntüsü (alanya.bel.tr)

\section{Mescit:}

Hanın müştemilatından olan mescidin ana binadan ayrı olarak doğu cephesinde inşa edildiği görülmektedir. Enlemesine uzanan hanla bütünlük oluşturacak şekilde tasarlanmıştır. Mescidin diğer yapılarda pek rastlanmayan tarzda gösterişli bir taç kapısı vardır. Mescid portali iki yandaki payanda kuleleri ile adeta kuşatılmış gibidir. Mescide üç basamaklı bir merdivenle çıkılır. Secde kısmı duvarın içine girinti yapan mihrap, kesme taşlardan yapılmıştır. Mihrap nişi beş kenarlıdır. Kavsaranın üzerinde ise yatay olarak yerleştirilmiş devşirme malzeme bulunmaktadır (Eravşar, 2017, s. 84).

\section{Süsleme:}

Taç kapılarının dışında kervansarayda kayda değer bir süsleme unsuru yoktur. Taç kapı üzerinde, köşelerdeki trompların altında uzanan, yarım yıldız formlu geometrik şekillerle bezenmiş şerit süsleme unsuru olarak göze çarpar. Bu süsleme biçimi diğer hanların tezyinatında da sıkça kullanılmıştır.(Eravşar, 2017, s. 87).

Selçuklu döneminin önemli konaklama merkezlerinden biri olan han günümüzde eğlence merkezi olarak kullanılmaktadır. 


\subsubsection{Kızlar Hanı}

Antalya'dan çıkışta Alanya ilçe merkezi sınırı içinde beşinci menzil Kızlar Hanı'dır.

Kızlar Hanı, Alanya karayolu üzerinde yaklaşık olarak Alanya kalesi hizasında bir yerde bulunmaktadır. Şehirdeki “Kızlar Mahallesi” adını bu handan almaktadır. Çekül Vakfínın İpek Yolu Kültür Yolu Haritası'nda yeri işaretlenmiştir.

\subsection{6. (Ikinci) Pazarcık Hanı}

Alanya-Anamur istikametindeki bir başka han, (İkinci) Pazarcık Hanı'dır. Gazipaşa ilçesi s1nırları dahilinde Bıçkıcı Köprüsü’nün üst taraflarında yer almaktadır. Çekül Vakfı'nın İpek Yolu Kültür Yolu Haritası'nda yeri işaretlenmiştir.

\subsubsection{Altıkapı Hanı}

Alanya-Anamur istikametinde (İkinci) Pazarcık Hanı'ndan sonra Altıkapı Hanı yer almaktadır. Selçuklular döneminde inşa edilmiş olan Altıkapı Hanı, Gazipaşa İlçesi’nin Yakacık I. Köyü sınırları içerisinde yer almaktadır. Yörenin siyah ve sarı renkli taşı ile kayan taşından araları Horasan harcı ile doldurularak inşa edilmiş bir yapıdır. Çekül Vakfi'nın İpek Yolu Kültür Yolu Haritası'nda yeri işaretlenmemiştir.

Yaklaşık dikdörtgen planlı bir yapıdır. Kervansarayın doğu - batı yönünde yuvarlak kemerli altı giriş kapısı, birbirine bitişik altı yuvarlak tonozlu mekâna açılmaktadır. Bu mekânların önünde, yuvarlak tonozlu payandalarla taşınan revaklar yer almaktadır. Revak açıklıkları kemerli kapılarla sağlanmıştır. Bunlardan üç tanesi günümüze sağlam şekilde ulaşmış olup diğerleri yıkılmıştır. Revakların kuzey yönünde birbirine paralel altı uzun mekân yer almaktadır. Mekânlar birbirine kemerli kapılarla bağlanmış bulunmaktadır. Kapalı mekânların içinde yer alan mazgal delikleri aydınlatmayı sağlamaktadır. Kervansarayın yan tarafında bir de köşk bulunmaktadır (Altkapı Han). Çekül Vakfi'nın İpek Yolu Kültür Yolu Haritası'nda yeri işaretlenmiştir.

Altıkapı Hanı'ndan Ermenek'e geçilip geçilmediğini bilmiyoruz. Arada bir veya iki hanın bulunması halinde rahatlıkla Ermenek'e geçilebilir gibi bir durum var görünmektedir. Ancak aradaki dağların buna müsait olup olmadığını bilmiyoruz.

\subsection{Manavgat-Kubadabad Güzergâhındaki Kervansaraylar}

Manavgat'tan kuzey istikametine uzanan iki ana yol vardır. Bunlardan biri Manavgat-Kubadabad, diğeri ise Manavgat-Konya yoludur. Bu iki ana yolun dışında Anadolu'nun içlerine kadar giden başka talî yollar da vardır.

Kubadabad, Beyşehir gölünün Batı yakasında Anamas dağlarının eteğinde 1236 yılında I. Alâeddin Keykubad tarafından yaptırılmış olan Selçuklu sarayı külliyesidir. Külliye bünyesinde biri büyük, diğeri küçük iki asıl saray, iki bölümlü bir kayıkhâne, cami, hamam, fırın, mutfak, depo, asker barınakları gibi çeşitli yapılar bulunuyordu. Alâeddin Keykubad bu 
sarayı yaptırırken sarayın çevresine de bir şehir kurulmasını emretmiştir. Ancak sonradan bu hususta çok fazla muvaffak olamamışlardır.

Gerek Antalya'dan gerekse Alanya'dan çıkan kervanlar Manavgat'a kadar gelirler, buradan yukarıya farklı yollardan giderlerdi. Ancak Alanya istikametinden gelen kervanlar muhtemelen Kargı Han’a uğramadan yukarı çıkmaktaydılar. Manavgat-Kubadâbât Yol Güzergâhı Üzerindeki Kervansaraylar şunlardır:

\subsubsection{Kargı Han}

Manavgat’tan sonra Manavgat-Kubadabad yol güzergâhının ilk menzili Karg1 Han'dır.

\section{Yeri:}

Kargl Han,Alanya'nınbatısında,Manavgatsınırları içerisindekiBeydiğinköyünde Kargıçayının kuzeyinde, Kesikbel Dağı'nın zirvesinde İbradı yolu üzerinde bulunmaktadır. Taşağıl köyünün 20 km. kadar kuzeydoğusunda yer almaktadır. Kargı suyu kenarında kurulmuştur. Toroslardan Manavgat'a inen eski yol üzerindedir (Eravşar, 2017. s. 499). Bu güzergâh, Roma, Selçuklu ve Osmanlı dönemlerinde Akdeniz'i İç Anadolu'ya bağlayan yoldur. Eski yola ait herhangi bir kalıntı bulunmamakla birlikte, mevcut patika yolun eski yolu takip ettiği düşünülmektedir.

\section{Kitâbesi, bânisi ve inșâ tarihi:}

Taçkapının üst kısmında bulunan düz kavisli alanda, bir çukur bulunmaktadır. Binanın yapıldığ1 sırada burada bir kitâbenin olduğu anlaşılmaktadır (Erdmann, 2008: 253-254). Kitâbe kapıp olduğu için kervansarayın yapım tarihi hakkında kesin bilgi sahibi değiliz. Ancak yapı şekli ve tarzı itibariyle Anadolu Selçukluları döneminde inşa edildiği anlaşılmaktadır. Özellikle şehir dışındaki kervansaraylar organize bir sistemin parçası olması sebebiyle Kargı Han'ın da 12361246 yılları arasında inşa edilmiş olduğunu düşünülmektedir. Karg1 Han'da, Kırkgöz Han’da bulunan bazı hatalar giderilmiş olduğu için ondan sonra inşa edildiğini söyleyebiliriz.

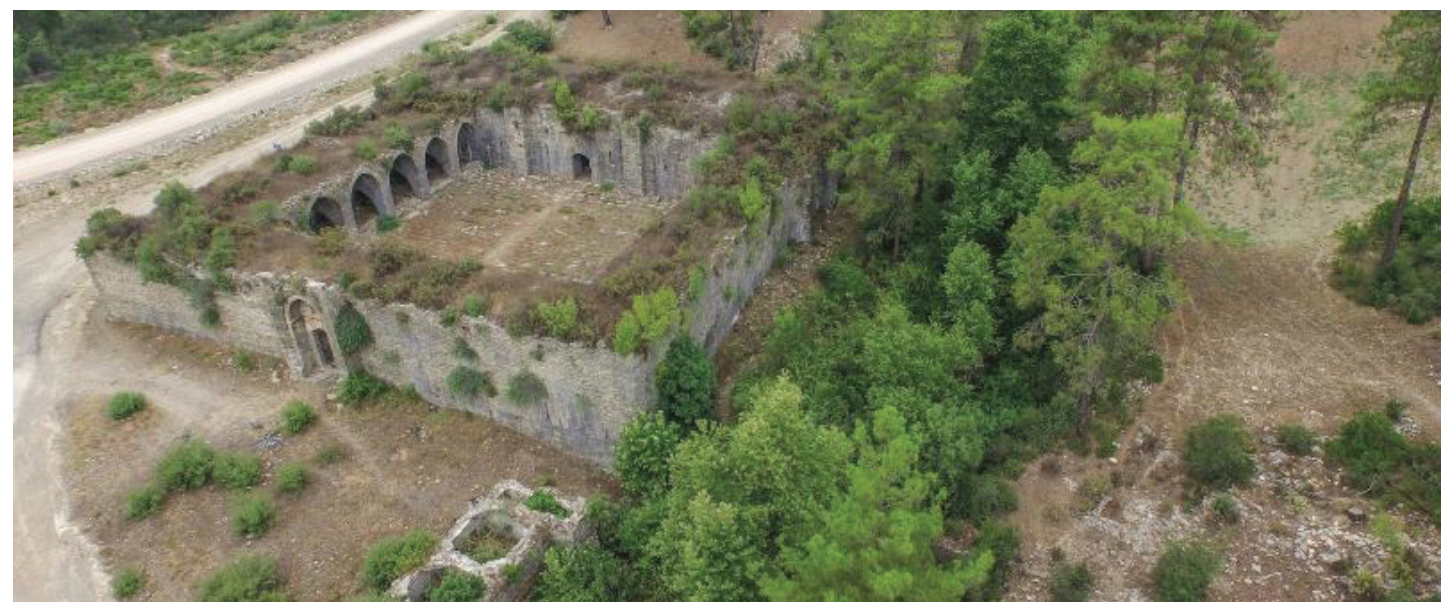

Resim 16: Karg1 Han'1n havadan görünüşü (turkishhan.org) 


\section{Planı ve yapı özellikleri:}

Plan bakımından avlunun yapıya hakim olduğu yapılar grubunda değerlendirilmektedir. Plan açısından daha çok Kırkgöz Han’a; inşaat özellikleri bakımından ise Şarapsa Han’a benzemektedir (Eravşar, 2017. s. 505).

$46 \mathrm{~m}$ eninde, $50 \mathrm{~m}$ boyunda olan yapı, 2300 metrekarelik bir alanı kapsamaktadır. Yönü kuzeye doğru bakmaktadır. Ana yapısı itibariyle bir avlunun etrafındaki açık ve kapalı odalardan ve ana salondan meydana gelmektedir. Orta avlunun etrafında sıralanmış olan odalarının hepsinin tavanında hava bacaları bulunmaktadır.

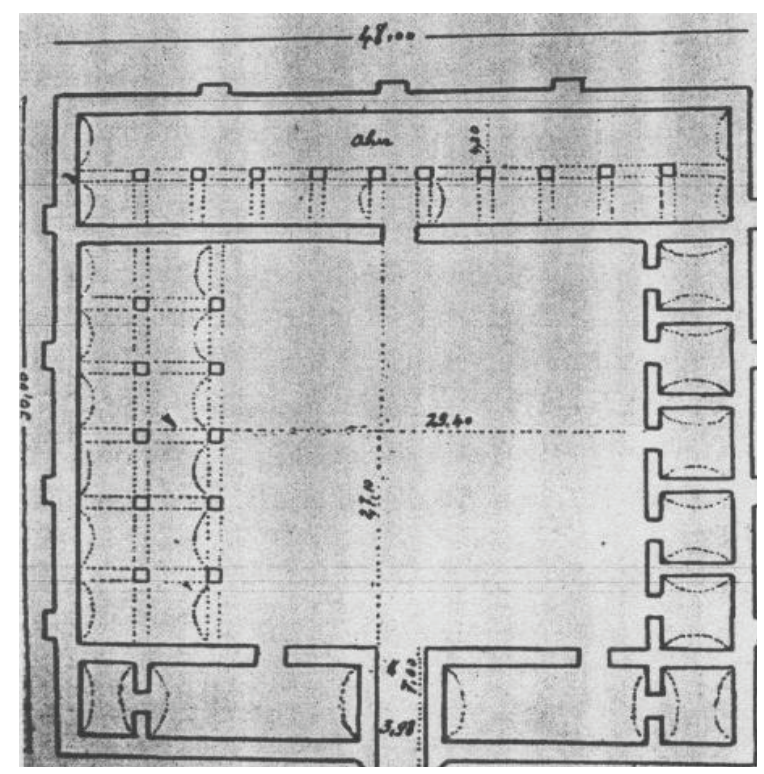

Şekil 5: Karg1 Han, Plan Rölövesi (Fikri Erten)

Erdmann, Kargı Han'ın özelliklerini hakkında şu bilgileri vermektedir: Avlu cephesinde payanda yoktur. Payandaların bulunduğu sol tarafta, köşeden 28 m mesafeden sonra başlar. Sağ dış duvar, duvar boyunca moloz taşlar ve toprakla doldurulduğu için ulaşılmaz haldedir. D1ş duvarların kalınlığı iki m. civarındadır. Duvarların içi dolgu malzemeleriyle doldurulmuş olup çift taraflı olarak yontma taş malzeme ile örülmüştür. Ana giriş kapılarında, sütunlarda, kemerlerde, kemerli kavislerde ve kısmen basamaklarda daha iyi işlenmiş kesme taşlar kullanılmıştır. Sağ taraftaki yüksek kayalıklar üzerindeki avlu cephesinin ayaklarında ise çok farklı büyüklüklerde kesme taşların kullanıldığı görülmektedir.

Yer döşemeleri büyük levhalardan oluşan avlunun arka tarafinda, büyüklük açısından Kırkgöz Han'ın ana salonu ile örtüşen 11,50 m derinliğinde ve $45 \mathrm{~m}$ genişliğinde bir ana salonu vardır. Ana salondaki tonozların arasına yükü hafifletme tonozu yerleştirilmiştir.

"Avlunun sol tarafinda altı tane üzerinde iki adet basık, yuvarlak, sivri kavisli kemerin dış duvara uzandığı tonozları kemersiz revak yer almaktadır. Avlunun sağ tarafında bütün sivri tonozları dış duvar istikametinde uzanan altı tane kapalı oda bulunur. Bunlar birbirleriyle bağlantılı 
değildir, aksine her birisine avludan bir kapı yardımıyla girilebilmektedir. Güney duvarının ortasında basit, yarım yuvarlak bir niş vardır, burası hanın mescididir. Giriş duvarında avlunun yan odaları, yani revaklar sol tarafa doğru, odalar sağ tarafa dış duvara kadar devam eder.”

"Avludaki kapalı odaların kapıları, kabaca işlenmiş taşlardandır. Tonozlarda kesme taşlar görülmez. Avlu ve basamaklarda büyük taş levhalardan oluşan zemin döşemeleri vardır. Cephenin sağ köşesinin yaklaşık 5 m önünde iki kubbeli küçük basit biçimli bir hamam vardır ve cephenin sol köşesinin yaklaşık 15 m önünde 5 m. x 10 m. ölçülerinde bir binanın yıkıntıları vardır, bir tuvalet olması muhtemeldir."

"Genel durumu iyidir. Ana salon, görünüşe göre kısa süre öncesine göre yemliklerin parçalanmasına kadar çok iyi bir durumdaydı. Avluda bulunan revaklardaki basamaklar çok şiddetli tahrip olmuşlardır. Sağdaki odaların iç tefrişatlarından geriye hiçbir şey kalmamıştır. Rahatsız edici büyük pencereler daha sonraki devirlerde açılmıştır. Avlu ana giriş kapısının üst bölümü daha kısa süre önce yıkılmış gibi görünmektedir. Kesme taşları zeminde durmaktadır. Ana salon kapısında büyük bir tahribat görülmektedir. Döşemeleri hâlâ iyi görünen avlu, bitki örtüsünden korunmuş, duvarları ise maalesef yakın gelecekte başka hasarlara maruz kalacakmış gibi görünmektedir. Issız konumu, hanı taşlarının talan edilmesine karşı korumuş, hatta üstüne üstlük belli manada bakımı yapıldığı hissi uyandırmaktadır. Belki de kısa süre öncesine kadar münferit yolcular tarafından olsa bile hâlâ kullanılmaktaydı.”

"Karg1 Han'da bütün odalar, kareye benzer bir avlunun etrafında bulunmaktadır. Ana salonların ve avlunun hiç bir istikamette birbirinden ayrılması söz konusu değildir. Bu inşa stili Eyyubiler ve Memluklular devrinden kalma Suriye Kervansaraylarının karakteristik bir biçimidir. Bunlara avludaki iki veya üç kapıdan girilebilir. Ana kapı, iki simetrik yerleştirilmiş odayla ayrılır ve imkân olursa karşısında bulunan yere bir eyvan yerleştirilir. Karg1 Han, Eyyubiler devrinin Suriye hanlarının yapılış prensibi karşılaştırıldığında, detaylarda önemli farklar mevcuttur. Meselâ avlunun sol tarafındaki açık kubbeli yapılar (revaklar), Suriye'de bilinmez. Avlu tarafının küçük odalara bölünmesi, orada görülmez ve duvarların dış tarafındaki payandalar ve ana giriş kapısının vurgulanması da Suriye tarzına uymaz. Bütün bunlar İç Anadolu kervansarayları için tipik özellikleridir. Hal böyle olunca Kargı Han, Suriye hanlarının temel özellikleri ile İç Anadolu unsurlarını birleştiren özgün bir kervansaray olmaktadır” (Erdmann, 2008, s. 250-254).

Kırkgöz Han ile karşılaştırıldığında Kargı Han biraz daha gelişmiş bir biçim arz eder. Her iki yapının ana salonları, yaklaşık aynı büyüklüktedir. Ancak Kırkgöz Han’ın ana salonu kötü 1şıklandırılmış olduğundan kasvetli bir intiba uyandırmaktadır. Karg1 Han ise, 14 penceresi ile alı̧̧ılmışın dışında daha aydınlıktır. Kubbenin iki paralel tonoza bölünmesi da odayı daha iyi ayırmaktadır. Basamakların düzenlenmesi daha uygundur. Kırkgöz Han'da bunlar odanın girişinin karşısındaki yerde bulunur. Kırkgöz Han'da hayvanlar ana salonun (holün) ön bölümünde kalıyorlardı. Kargı Hanı'nda ise kapı kemerinin altının geçiş görevi yaptığı giriş kısmında durmaktaydılar. Yani hayvanlar ana salonun arka bölümünde duruyorlardı. Karg1 Han'ın avlusu, Kırkgöz Han’a oranla Evdir Han’a daha yakın olup Kırkgöz’ünki gibi derin değildir. Bu yüzden oda dağılımı daha gelişmiştir. Kırkgöz Han'da sadece arka sağda ve solda kapalı odalar bulunmaktadır; Kargı Han'da avlu tarafındaki odaların tamamı kapalıdır. Aynı şekilde avlunun giriş 
tarafı daha zengin bölünmüştür ve Kırkgöz Han'da göze çarpan hoş olmayan odaların köşedeki odalara bölünmesinden kaçınılmıştır (Erdmann, 2008, s. 255-256).

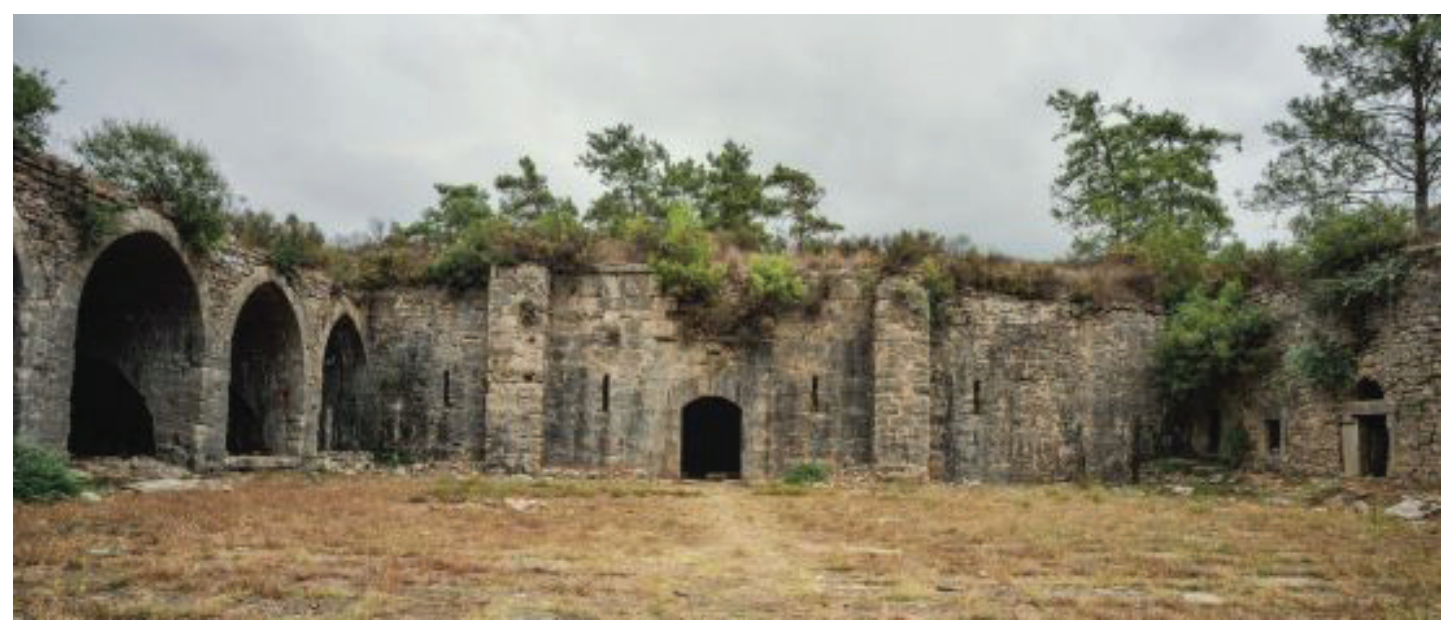

Resim 17: Karg1 Han'1n içeriden bir görüntüsü (Eravşar 2017, turkishhan.org)

\section{Taçkapısı:}

Taçkapısı günümüze sağlam şekilde ulaşmıştır. Genişliği 6 metredir. Dikdörtgen şeklindeki taç kapı ana duvardan 1.30 m kadar dışarıya doğru çıkmış vaziyettedir. Taçkapının kalın bir çerçevesi vardır, fakat süssüzdür. "Çerçevelerin iç kısma döndüğ̈̈ yerde zeminden $85 \mathrm{~cm}$. sonra kesilir, oradan ana kapı mihrabı olarak devam eder. $1.30 \mathrm{~m}$ derinliğindeki sivri kavisli mihrabın alın tarafı içeriye doğru basık bir şekilde devam eder ve kapının üst kısmındaki kavisli takviye çıkıntısına bağlanır. Kemer ile dış çerçeve yapısı ile kemer arasındaki kama boştur. Köşe sütunceleri ve yan oturma yerleri mevcuttur. Kapı genişliği 2,30 m.yi bulur.” (Erdmann, 2008, s. 253-254).

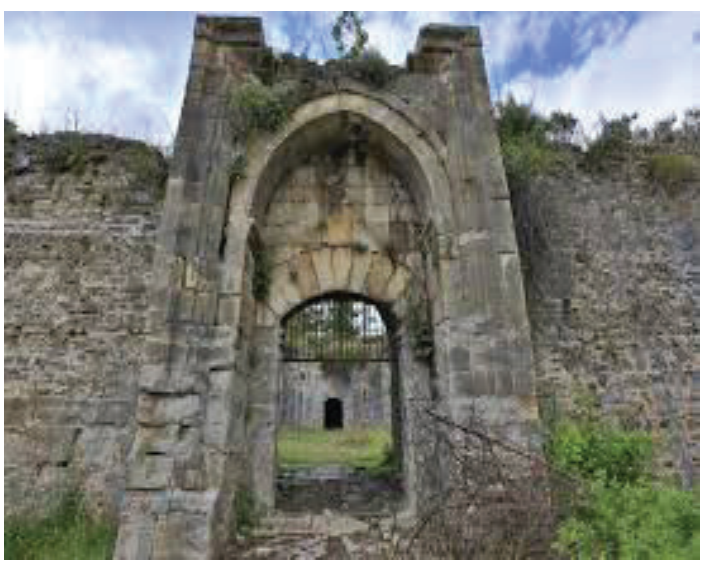

Resim 18: Karg1 Han'ın Portali (Eravşar 2017, turkishhan.org) 


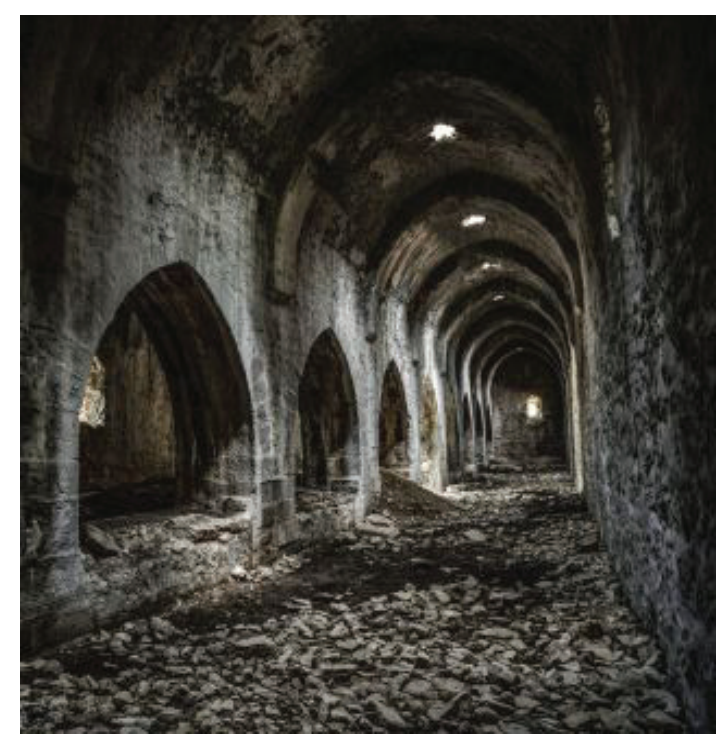

Resim 19: Karg1 Han'ın içeriden bir görüntüsü (Eravşar 2017, turkishhan.org)

\section{Mescit:}

Mescit yapının kuzeydoğu köşesinde yer alır. İçeriye düz lentolu ve söveli bir kapıdan girilir. Aydınlatma, lentonun üzerindeki Bursa kemeri ile sağlanmaktadır. Mihrabı güney duvarını ortalayacak şekilde yerleştirilmiştir (Eravşar, 2017, s. 503).

\section{Restorasyonu:}

Yapının ana elemanlarının tamamı mevcuttur. Kapalı kısmı büyük oranda sağlamdır. Avlunun doğu kısmında bulunan platformunda tahribat vardır. Han hamamının bölüm duvarları kısmen sağlam olup üst örtüsü tahrip olmuştur (Eravşar, 2017, s. 505). Yapının restorasyon süreci başlatılmıştır.

Kargı Han aynı zamanda kavşak noktasında yer alan hanlardan biridir. Onu sadece Kubâd âbâd yolu üzerindeki bir han olarak değerlendirmek doğru olmaz.

\subsubsection{Burma Han}

Manavgat'tan sonra Manavgat-Kubâdâbâd yol güzergâhının ikinci menzili Burma Han'dır. (Kunduracı, 2017:190). Antalya ili Manavgat ilçesine bağlı Burmahan köyü sınırları içinde yer almaktadır. Burmahan köyü, Manavgat'in kuzeyinde ilçe merkezine 68 km, Antalya'ya 110 km uzaklıktadır. Çekül Vakfi'nın İpek Yolu Kültür Yolu Haritası'nda yeri işaretlenmiştir.

Burmahan'dan sonra, Ebül-Hasan Hanı'na çıkılır ve oradan Kubâdâbâd'a ulaşılır. 


\subsection{Manavgat-Sırtköy-Eynif-Beyșehir Güzergâhındaki Kervansaraylar}

\subsubsection{Homa (Oymapınar) Hanı}

Alanya'dan çıktıktan sonra birinci menzil Şarapça Hanı, ikinci menzil Alara Han, üçüncü menzil (Birinci) Pazarcık Hanı veya Oymapınar Hanı'dır. Oymapınar'dan sonraki dördüncü menzil Sırtköy (Murtbeli) Tol Hanı, beşinci menzil Derebucak Tol Hanı'dır. Oradan Beyşehir istikametindeki diğer kervansaraylardan geçilerek Beyşehir'e ulaşılır, oradan da Konya’ya geçilir.

Manavgat Oymapınar'da eski bir hanın varlığından söz edilmekle birlikte günümüzde handan herhangi bir iz kalmadığı için (Cansız, 2018, 1, 632), yeri, planı ve yapı özellikleri hakkında bir değerlendirmede bulunmak mümkün değildir. Büyük ihtimalle han, Oymapınar baraj gölü altında kalmıştır.

\subsubsection{Sırtköy Tol (Murtbeli) Hanı}

Oymapınar Hanı'ndan sonraki menzil Sırtköy (Murtbeli) Tol Hanı'dır.

\section{Yeri}

Sırtköy Tol Hanı, Alanya-Beyşehir-Konya anayol güzergâhında Manavgat ilçesinin yaklaşık 30 km kuzey-batısındaki Sırtköy sınırları içinde yer almaktadır. Sırtköy, Kartallık Tepesi’nin sırtına yaslanmış bir orman köyüdür. Etenna adlı antik kentinin eteğinde yer almaktadır. Tol Hanı, Sırtköy'ün 7 km. doğusunda Üç Irmak mevkiinde bulunmakta ve kervan yolunun Homa (Oymapınar) ile İbradı Eynif Tol Hanı arasındaki menzili oluşturmaktadır (Cansız, 2018, s. 630). Yani Alara'dan çıktıktan sonra Homa (Oymapınar) Hanı'na gelinir. Oymapınar'dan çıktıktan sonra ise Sırtköy Tol Hanı'na varılır. Bundan sonraki menzil Eynif Tol Hanı'dır. Buradan da Beyşehir üzerinde Konya'ya ulaşılır.

Beyşehir-Derebucak-İbradı-Serik güzergâhı Romalılar tarafindan da kullanılan ticari bir yoldu ve Anadolu'da üretilen mallar bu yoldan Akdeniz'e indirilirdi.

\section{Kitâbesi, bânisi ve inșa tarihi:}

Hanla ilgili dört parçadan oluşan yazılı taş belge bulunmaktadır. Bunlardan biri Sırtköy'de Ali Rıza Çevik'in evinin duvarına yerleştirilmiş bulunmaktadır ve bu kısım iki parçadan ibaret olan kitabenin bir parçasını teşkil etmektedir. Bu parça halâ ilgili kişinin evinin duvarında yer almaktadır. Diğger parçalar ise kimliği bilinmeyen kişiler tarafından Side Müzesi’ne getirilmiş olup, üst üste konulmak suretiyle Side Müzesi’nin bahçesinde sergilenmektedirler. Mustafa Cansız bunların resimlerini çalışmasında yayımlamıştır. Cansız'ın yorumuna göre bu parçalar Sırtköy Tol Hanı'na ait olmalıdır. Bölgede başka hanlar bulunmakla birlikte, Murtbeli Hanı ile Beydiğin Hanı (Karg1 Hanı) farklı bir yol güzergâhında bulunmaktadır; Alara Han'ın kitabesi eksik olsa da, eksik olan parçalar bunlar değildir; bu parçaların Eynif Tol Hanı'ndan getirilmiş olması da imkânsız görünmektedir, zira bu han çok eskiden yıkılmış olup bölgeye de bir hayli uzaktır; Manavgat Oymapınar'da olduğu var sayılan kervansaraydan günümüze hiçbir iz 
kalmamıştır. Şu halde tek ihtimal bu parçaların Sırtköy Tol Hanı'na ait olmasıdır. Esasen en önemli parçasının Sırtköy'deki bir evin duvarında bulunması bunun en önemli kanıtı sayılmalidir.

Hana ait dört yazıttan ikisi kitabedir. Kitabede şunlar yazılıdır:

“Emera bi-‘imâreti hâze'l-hân fî eyyâmi devleti es-sultânü'l-a'zam 'ale'dünyâ ve'd-dîn Ebü’lfeth Keykubâd bin Keyhüsrev kasîmü emîrü'l-mü'minîn el-'abdü'z-za'îf ve’n-nahîf Ayaz Şarâb-sâlâr hafezena'llhü fî̀ Muharrem sen tis'a ve "işrîn ve sitte mie"

Metnin Türkçe tercümesi şöyledir:

"Bu hanın yapılmasını, büyük sultan, dünyanın ve dinin ulusu, fethin babası (şehirler fatihi) olan Keyhüsrev oğlu Keykubad'ın saltanatı zamanında, emîrü'l-mü'minînin (sultanın) ülüştesi zayıf ve aciz bir kul olan Ayaz Şarâb-sâlâr'a emretti. Allah bizi korusun. Muharrem 629/ Ekim-Kasım 1231.” Bu kitabeden açıkça anlaşıldığı üzere hanın yapılmasını Gıyaseddin Keyhüsrev'in oğlu I. Alâeddin Keykubâd (1220-1237) emretmiştir. Hanın inşa tarihi 1231 yılıdır. Buna göre Sırtköy Tol Hanı, Alanya yakınlarındaki Alara Han ile aynı zamanda yapılmış olmaktadır.

Hanı yaptıran kişi ise Selçuklu Devlet adamı Emir Esedüddin Ayaz'dır. Esedaddin Ayaz, I. Giyaseddin Keyhüsrev, I. İzzeddin Keykavus ve I. Alâeddin Keykubad dönemlerinde uç beyi, atabey, subaşı gibi görevlerde bulunmuştur. Alaeddin Keykubad döneminde ise saray teşkilatının şarabsâlr'ı yani içki tadımcısı idi (Cansız, 2018, s.236-237)

\section{Planı ve yapı özellikleri:}

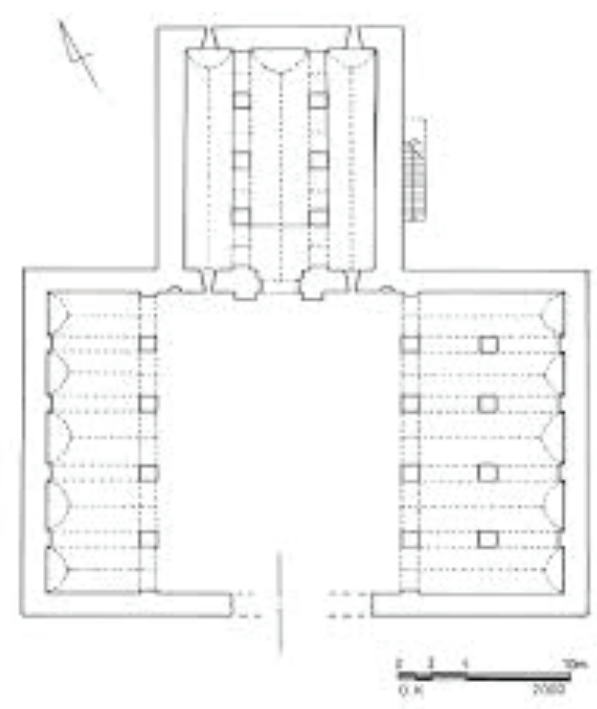


Alanya-Kubadabad arasında sıralanmı̧̧ Selçuklu dönemi hanlarından biri olan Sırtköy Tol Han1, doğu-bat1 yönünde inşa edilmiştir. Kervansarayın girişi doğudaki basık kemerli kap1dan sağlanmaktadır. Taçkapı, yapının bünyesinden öne doğru taşırılmış olup bugün hala bir kemer şeklinde ayaktadır. Kervansarayı çevreleyen dış ana duvarlarından kuzey, güney ve batı duvarları dıştan üçgen payandalarla desteklenmiştir. Hanın kapalı mekânı, girişe dik olarak düzenlenmiş beş sahından ibarettir. Sahınların sivri kemerlerle taşınan taş tonoz örtülü olduğu anlaşılmaktadır (Kundurac1, 2017, s. 189-190).

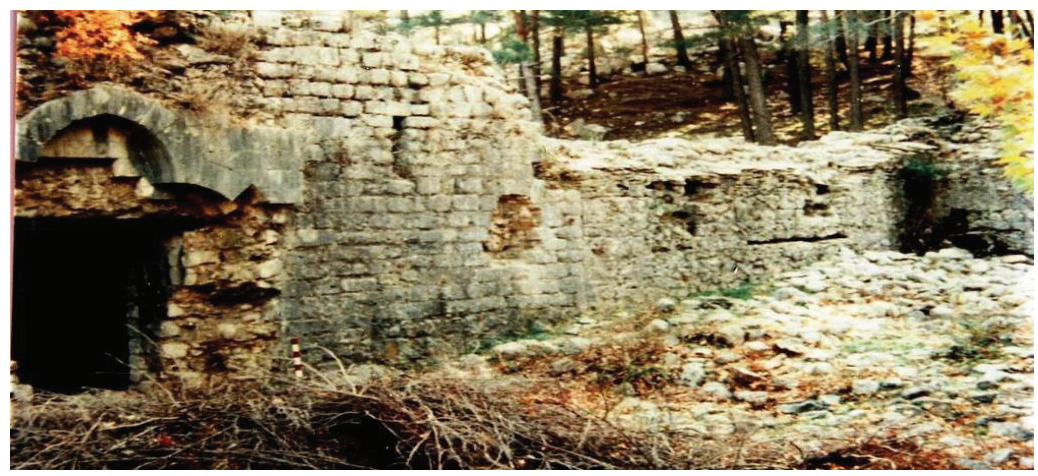

Resim 20: Sırtköy (Murtbeli) Hanı -Manavgat (O. Kunduracı)

Çekül Vakfi'nın İpek Yolu Kültür Yolu Haritası'nda yeri işaretlenmiş olup adı Mutbeli şeklinde yazılmıştır.

Alara, Oymapınar, Murtbeli istikametinden gelen yol, doğu istikametinden, yani Kargihan'dan gelen yol ile yukarıda İncirsivrisi yakınlarındaki Atizi'nde birleşir. Sonra birleşen bu yol Kesikbel'den geçerek Eynif Tol Hanı'na ulaşılır (Cansız, 2018, s.236) .

\subsubsection{Eynif Tol Hanı}

Sırtköy (Murtbeli) Tol Hanı'ndan sonraki menzil Eynif Tol Hanı'dır. Esasen kervansarayın asıl adının bilinmediğini söyleyebiliriz. Yöre halkı "Tol” kavramını "taş yapı veya kemerli taş yap" anlamında kullanmaktadır. Genel olarak halk ağzında "tol” şu üç anlamda kullanılır: "1. Taş kemer veya taş kemerlerle yapılmış ev, oda, kap1 vb. şey. 2. Yayla veya bahçe kulübesi. 3. Küçük köy” (TDK). Buna göre hanın adı bir nevi "Taşhan” olmaktadır. Nitekim bazı yörelerde bazı hanların ismi doğrudan Taşhan olarak bilinir. İsmi bilinmeyen bu tür hanlara isim vermek gerektiği zaman, tol kavramının başına o yörenin adı getirilir: Eynif Tol Hanı, Ortapoyam Tol Hanı, Derebucak Tol Hanı gibi.

\section{Yeri:}

Eynif Tol Hanı, Alanya-Beyşehir yolu üzerinde Eynif Ovası'nın güneyinde Akdağ'ın ovayla birleştiği düzlükte, Antalya-İbradı İlçesine bağlı Başlar Köyü yakınlarında bulunmaktadır. Beyşehir-Derebucak-İbradı bağlantısının sağlandığı yola yakın bir noktada Derebucek ilçe merkezine $30 \mathrm{~km}$ mesafededir. Doğu ve batısı Toros dağları ile çevrili Eynif Ovasına nazır bir 
yamaçta kurulmuştur. Kervansarayın kuzeyindeki önceki yerleşim yeri Kubâdâbâd'tır. Güney yönde yol, denize ulaşarak Manavgat ve Alanya istikametine doğru uzamaktadır. Eynif Tol Hanı'ndan sonra güney istikametteki ikinci han yeri bilinmeyen Burma Hanı'dır. Burma Hanı'ndan sonra Toros dağlarından kademeli olarak inilerek Kargı Hanı'na ulaşılır (Eravşar, 2017, s. 114).

İlk çağlardan beri İbradı bölgesi, Anadolu'nun içlerinden Akdeniz’e inmek için izlenen yol güzergâhlarından birinin üzerinde bulunuyordu. Aradaki bağlantı Kesikbeli üzerinden sağlanıyordu. "Torosları, Demirkapı geçidi ile aşan bu yol güzergâhına kısaca Kesikbeli denilmektedir. Burası, Alanya, Manavgat ve Antalya bölgesini İbradı'nın batısından Beyşehir bölgesine bağlayan bir dağ geçididir. Kesikbeli yolunun geçtiği güzergâh, Selçuklu döneminde devletin başkenti Konya ile Antalya bölgesini (Antalya ve Alanya iskelesi) birbirine bağlamak için Selçuklu Sultanı I. Alâeddin Keykubad tarafindan yer yer eski yol teknikleri kullanılarak açılmıştır. Yol güzergahı; Taşağıl'dan sonra Karg1 Han (1237 - 1246), Beldibi Han, Atizi, Çaltılıkuyu ve Gelintaşı'nı, ardından da Demirkapı geçidini geçerek, Alikesiği ve Bahadın olduğundan, Tol Han'a ulaşır. Eynif, Üzümcü ve Sobuca'dan sonra Tepsili han ve Dalkatıran hanlarını geçerek Gembos'a çıkar ve oradan Beyşehir'e ulaşır. Selçuklular döneminde bu yol güzergahı üzerinde, Antalya - Kesikbeli, Beyşehir - Konya arasında toplam 11 kervansaray bulunmaktadır.”(Kervan ve Tarihi Yollar, 2019).

\section{Kitâbesi, bânisi ve inșâ tarihi:}

Kervansaray büyük ölçüde yıkıldığı için kitabesi de kayıptır. Nitekim mevcut kalıntılar arasında kitabeye rastlanmamıştır. Plan itibariyle Alara Han’a benzerliği dikkati çekmektedir. Kitabesi bulunmasa da planı ve güzergâhı itibariyle 13. yüzyılın ilk yarısında yapılmış olan Selçuklu dönemi kervansaraylardan biri olduğu hususunda şüphe bulunmamaktadır.

\section{Planı ve yapı özelliği:}

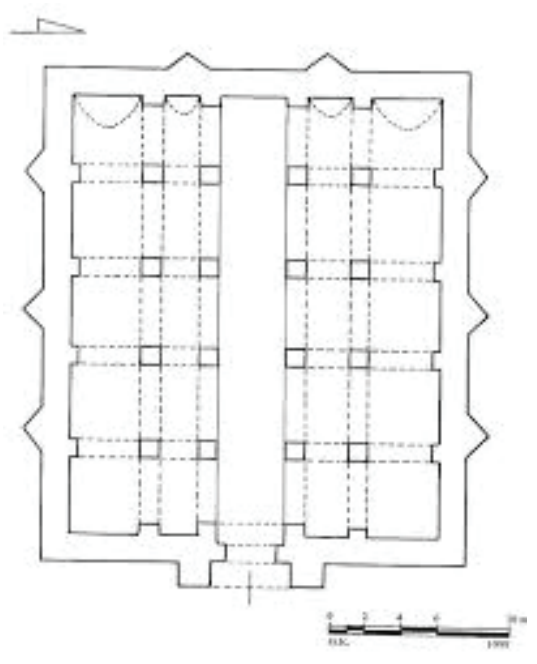

Şekil 7: Eynif Tol Hanı (O. Kunduracı) 
Kervansaray doğu-batı yönünde uzanan beş sahınlı bir yapıdır. Kervansaraya giriş doğu tarafındaki basık kemerli anıtsal bir kapıdan yapılmaktadır. Taç kapısının (portal) yarıya yakın kısmı toprağa gömülüdür. Kesme taştan yapılmış olan söveleri ve basık kemeri hala ayakta durmaktadır. Yapının dış beden duvarları halen mevcuttur. Kuzey, güney ve batı duvarları dıştan üçgen payandalarla desteklenmiş bulunmaktadır. Kervansaray girişe göre beş sahınlı bir düzenlemeye sahiptir. Ortadaki sahının üzerinin açık olduğu anlaşılmaktadır. Bina sağlam iken sahınlar, sivri kemerlerle taşınan tonoz örtüye sahipti. Eynif Tol Hanı'nın yapısı, açık ve kapalı avlusu tek mekânda toplanmış konsantrik hanlar grubuna girmektedir (Kundurac1, 2017, s. 189).

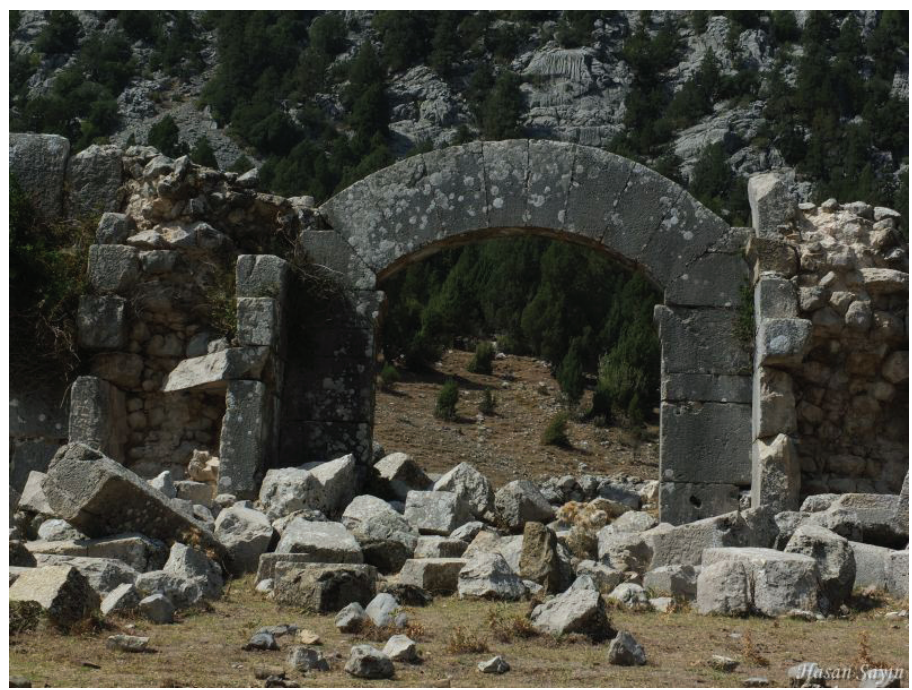

Resim 21: Eynif Tol Hanı'nın Portali (Hasan Sayın)

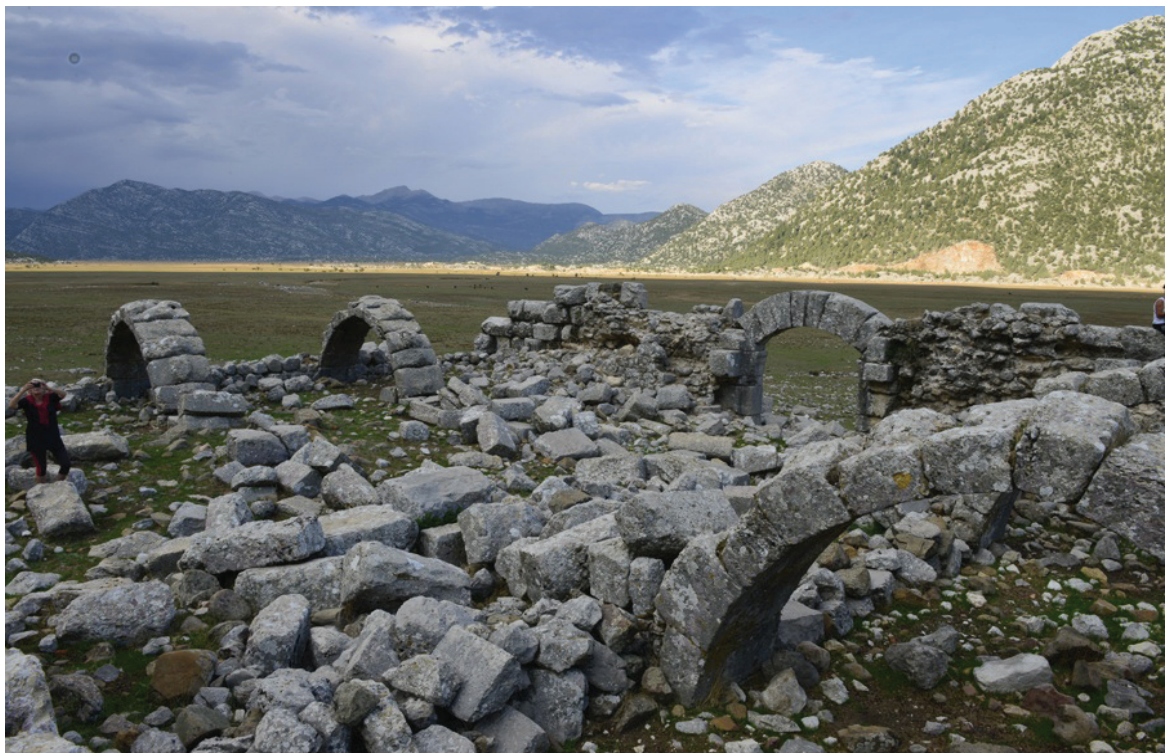

Resim 22: Eynif Tol Hanı'ndan bir görüntü (semerkanddanbosnaya.com) 
Eynif Tol Hanı'ndan sonra Ortapoyam Tol Hanı'na, oradan Derebucak Tol Hanı'na, oradan da Beyşehir üzerinden Konya'ya ulaşılırdı.

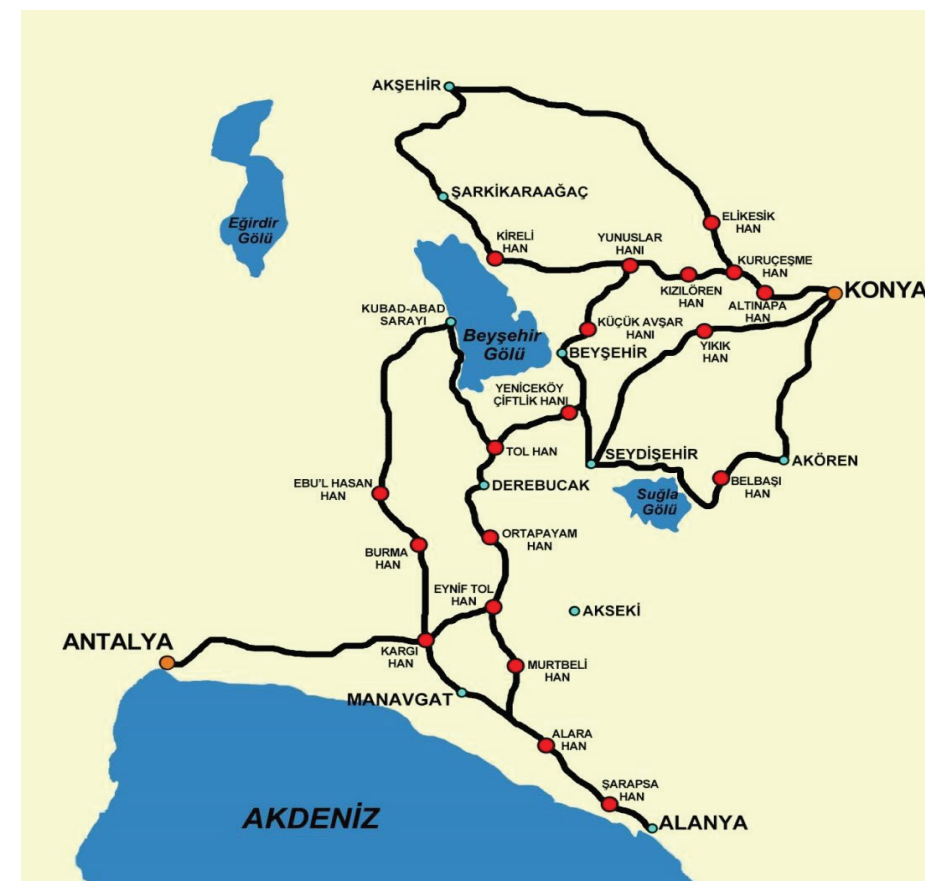

Harita 2: Konya cihetinden Akdeniz’e inen bazı kervan yolları (O. Kunduracı)

(Osman Kunduracı tarafindan hazırlanan bu harita Konya-Alanya kervan yollarını göstermek için yapıldığından Antalya'dan çıkan diğer yollar burada gösterilmemiştir.)

\subsection{Tâlî Yollar}

\subsubsection{Tașağıl-Kargı-Beldibi-Eynif-Beyșehir Güzergâhındaki Kervansaraylar}

Eynif (Murtbeli) Tol Hanı birkaç yolun kesiştiği yerde bulunur. Buradan geçen yollardan biri de Taşağıl-Karg1 Hanı-Beldibi Hanı-Eynif Hanı-Koca Oluk Hanı-Derebucak Tol Hanı yoluyla Beyşehir ve Konya'ya giden yoldur.

\subsubsection{Beldibi Han}

Beldibi Han, Sırtköy'ün (Etenna) yaklaşık 3 km kadar doğusunda ormanlık alanda yer almaktadır. Hanın 13. yüzyılda yapıldığı kabul edilmektedir. Han genel olarak kötü durumdadır. Ön avlunun duvarları büyük ölçüde yıkılmıştır. Avludaki enkaz ana binaya erişimi zorlaştırmaktadır. Dış duvarlardan sadece bazı kısımlar ayaktadır. Bunlar da çoğunlukla ana binanın bünyesindeki kısma aittir. Hanın kitabesi bulunamamıştır. Ana binanın çatısı yıkılmış olup 
üstü gelişigüzel kapatılmıştır. Şu anda bine keçi ağılı olarak kullanılmaktadır (Beldibi). Çekül Vakfı'nın İpek Yolu Kültür Yolu Haritası'nda adı zikredilmemiş ve yeri işaretlenmemiştir.

\subsubsection{Koca Oluk (Tolga) Han}

Eynif-Kesikbeli yolu üzerinde yer alan Koca Oluk Han bir Selçuklu eseridir. İbradı ilçesinin görülecek yerleri arasında sayılmaktadır (İbradı). Yine Eynif Ovası'nın doğusunda oldukça harabe halinde olan ve kitabesi kayıp olan bir handan bahsedilir. Bu hanın adı Tolga Han'dır (Gezi Notları) Koca Oluk Han ile Tolga Han aynı kervansaray olabilir. Bu hanın da sözünü ettiğimiz yol üzerinde bulunduğunu düşünüyoruz. Çekül Vakfı'nın İpek Yolu Kültür Yolu Haritası'nda adı zikredilmemiş ve yeri işaretlenmemiştir.

\subsubsection{Eynif Tol Han-Rodar Han-Bozkır-Akören veya Seydișehir Güzergâhı}

Eynif Tol Han'a kadar gelen kervanlar bazen daha kestirme bir yol olan Rodar Han üzerinden geçen yolu tercih ederlerdi. Rodar Han'dan sonra, Bozkır-Akören veya Seydişehir üzerinde Konya'ya ulaşı1ırd1.

\section{Rodar (Nodar) Hanı}

\section{İsmi:}

Rodar Hanı'nın isimlendirilmesi konusunda ilk harfin R mi, yoksa N mi olduğu hususunda uyuşmazlıklar vardır. Hanın ismi "Nodar" ve "Rodar" olmak üzere iki ayrı şekilde telaffuz edilmektedir. Yekta Demiralp, Tolga Bozkurt ve Robin gibi hanla ilgili ilk çalışmaları yapan araştırmacılar Nodar ismini kullanmaktadırlar. Çekül Vakfının hazırladığı "İpek Yolu Kültür Yolu Haritası"nda da Nodar ismi kullanılmıştır. Yine Osman Eravşar ve Yeşim Dilek akademisyenler ile Akseki Belediyesi ve Yarpuz köylüleri hanın ismini Rodar şeklinde anmaktadırlar. Bölgede ve bazı akademik çalışmalarda ağırlıklı olarak Rodar ismi kullanıldığı için biz de bu kullanım şeklini tercih ettik.

\section{Yeri:}

Rodar Han1, Akseki'yi Bozkır üzerinden Konya'ya bağlayan karayolunun yaklaşık 35. kilometresinde Yarpuz köyü yakınlarında Alacabel mevkiinde bulunmaktadır. Yarpuz köyü, Akseki'nin 20 km. kuzeydoğusunda yer alır. Han, oldukça derin bir vadi içinde bulunduğundan karayoluyla bu mevkiden geçerken görünmemektedir. Konya'dan çıkan kervan yolu Seydişehir'den geçerek Akseki üzerinden güneye iner ve Alacabel yakınlarındaki yol üstü kuruluşu olan Rodar Hanı'na ulaşırdı. Han, Akseki ve Bozkır tüccarlarının mallarını satmak için yola çıktıklarında hayvanlarının ve kendilerinin dinlenebildikleri tek nokta olmalıdır (Dilek, 2016, s. 842). Çekül Vakfı'nın İpek Yolu Kültür Yolu Haritası'nda yeri işaretlenmiştir. 


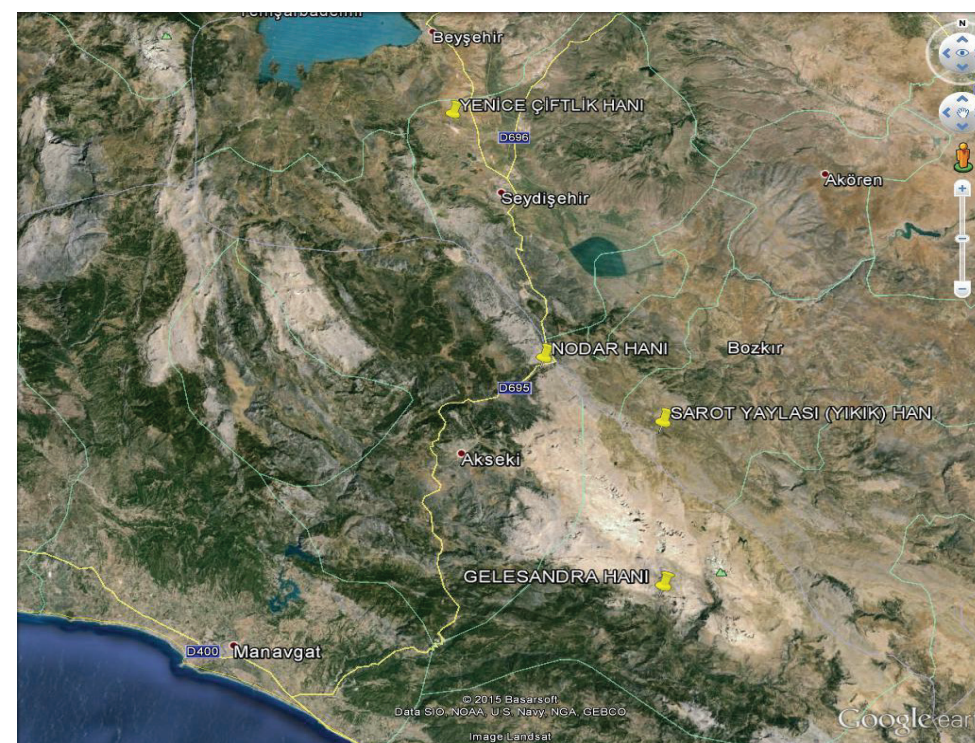

Harita 3: Seydişehir-Bozkır-Akseki-Gündoğmuş çevresindeki menzil hanları (Google Earth)

\section{Kitâbesi, bânisi ve inșa tarihi:}

Kervansarayın kitâbesi kayıptır. Bu sebeple ne zaman ve kimin tarafından yapıldı̆̆ 1 tam olarak bilinmemektedir. Plan şemasına bakarak veya Anadolu'daki benzer yapılarla mukayese ederek yaklaşık olarak bir tarih belirlemek de mümkün görünmemektedir. Ancak kervansarayın, Selçuklu kervan yolları üzerinde yer almaması ve bazı inşa özellikleri sebebiyle Anadolu Selçukluları dönemine tarihlenmesinin zor olduğu ileri sürülmüştür. Bu nedenle bazı araştırmacılar Akseki-Bozkır yolu üzerinde yer alan bu hanın bu iki merkez arasında gelip giden yolculara hizmet vermek üzere inşa edildiğini düşünmektedirler. Fakat başka bir açıdan bakıldığında Rodar Han'ın iki kervan yolunun ortasında kaldığı görülmektedir. Alanya'dan hareket eden bir yol Sabunlar, Erenkaya, Büyükilvat, Koras, Bademli, Kirli güzegâhını izleyerek Beyşehir'e; Anamur'dan hareket eden diğer bir yol da Aşağı Kuran, Kozanc1, Çavuş, Ermenek, Kişle, Taşkent, Hâdim, Bozkır ve Suğla gölünün güneyinden Seydişehir'e ulaşarak kuzeye ve kuzeydoğuya devam etmektedir. Bu durumda Rodar Han'1 Alanya'dan hareket eden yol ile Anamur'dan hareken eden yolun tam ortasında kalmaktadır. Bu takdirde Rodar Han'1 önemli hale gelmekte ve hanın Anadolu Selçukluları zamanında inşa edildiği düşüncesini hatıra getirmektedir. Bununla birlikte Yekta Demiralp, hanın XVII. veya XVIII. yüzyılda yapıldığı kanaatini taşımaktadır (Demiralp, 1994, s. 53-58). Tolga Bozkurt ve Robin Wimmel ise Rodar Hanı'nı bölgenin topografyası itibariyle yalnız Akseki-Bozkır yoluna koymanın pek doğru olamayacağı düşüncesindedirler. Yenice Köyü Veliler Çiftliği'ndeki han kalıntısı, Hatunsaray (Lystra) veya Erenkaya (Bulumya) üzerinden Derebucak Tol Hanı'na veya Akseki yönüne doğru yönelen yol güzergâhında ve muhtemelen Selçuklu dönemine ait bir menzilin varlığına işaret etmektedir. Dolayısıyla Seydişehir ilçesi sınırlarından geçerek, Akseki yolu üzerinden ve takriben bugünkü Seydişehir-Manavgat otoyoluna paralel bir kervan yolunun 14. yüzy1ldan önce de kullanılmış olması kuvvetle muhtemel gözükmektedir. Öte yandan, Karamanoğulları Beyliği’nin ülke topraklarında cereyan eden transit ticaretten önemli miktarda gelir elde ettiği 
bilinmektedir. Selçuklu Devleti'nin varisi oldukları iddiasıyla hareket eden Karamanoğulları Beyliği 15. yüzyıl sonlarına kadar Manavgat, Alanya, Anamur, Silifke ve Lamos (Yumurtalık) gibi Kilikya limanları ile başkent Konya arasındaki kervan yollarının kontrollerini ellerinde tutmuştu. Liman ve tersane imkânlarıyla Alanya, bu dönemde de Akdeniz ticaretindeki önemini sürdürmüştür. Bu bilgiler ışığında Alanya-Konya arasında henüz yeni keşfedilen ve kitabeleri bunmayan menzil yapılarının Beylikler Döneminden gelebileceklerinin de göz önünde bulundurulmas1 gerekmektedir (Bozkurt ve Wimmel, 1994, s. 1496-1497).

\section{Planı ve yapı özellikleri:}

Doğu-batı yönünde inşa edilmiş olan Rodar Hanı yaklaşık 50 metre uzunluğunda avlusuz bir handır. Plan bakımından Şarapsa Hanı'nı benzer. Ancak yaslandı̆̆ı yamacın şekline uydurularak inşa edildiği için yapı baş aşağı edilmiş hafif "V" harfini andırmaktadır. Yapı oldukça harap vaziyettedir. Bu haliyle yapı, sadece barınak kısmından oluşan hanlar grubuna girmektedir.

Kuzey duvarının tamamı, diğer duvarların da büyük bir bölümü toprak ve molozlarla örtülmüş durumdadır. Üst örtünün önemli bir bölümünün, yeni yolun yapımı esnasında yukarıdan yuvarlanan taşlar sebebiyle yıkıldığ 1 anlaşılmaktadır. Yaşlıların anlattığına göre hanın bu derece yıkılmasının temel sebeplerinden birisi de define arayıcılarıdır. 1950'i yıllara kadar kervansarayın bir hayli sağlam olduğu söylenmektedir. Bazı yaşlılar 20. yüzyıl başlarında bu handa gecelediklerini söylemektedirler. Büyük ölçüde yıkılmış olan kervansarayın şu anda sadece tek bir kemeri ayakta durmaktadır.
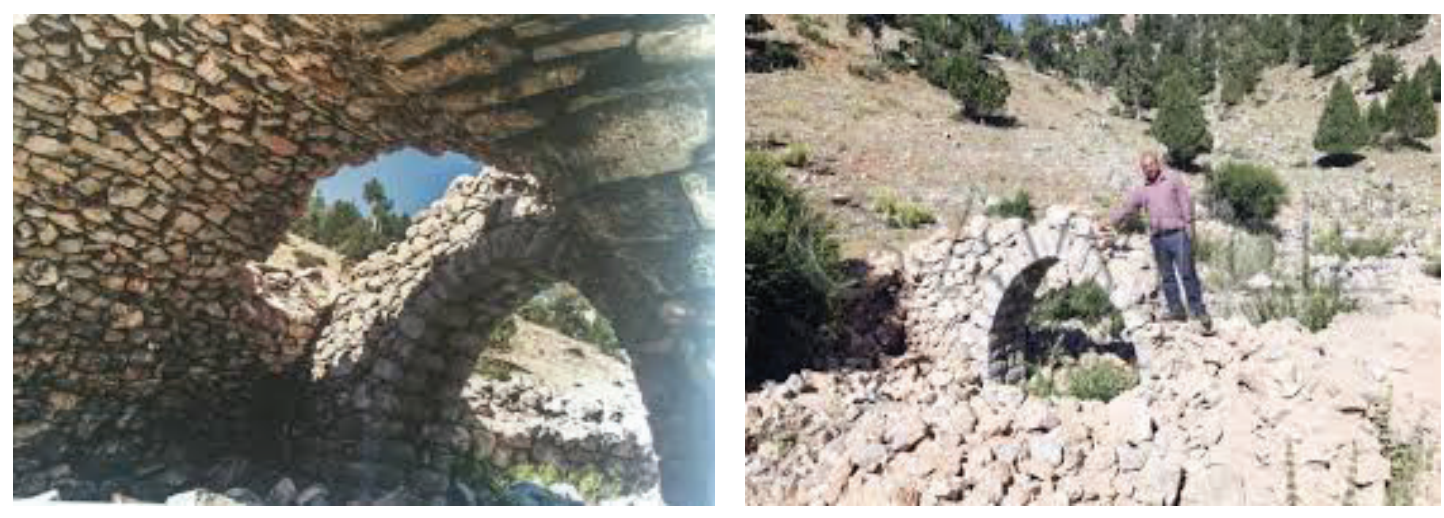

Resim 23: Rodar Hanı'ndan iki görüntü (O. Kunduracı)

Sivri kemerli geniş bir açıklık şeklindeki hanın girişi güney cephesinin ortasında yer almaktadır. Kapıdan, yaklaşık paralelkenar dörtgen planlı bir mekâna girilmektedir. Bu mekân sivri kemerli bir tonozla kapatılmıştır. Tonozunda kar şeklinde bir havalandırma ve aydınlık deliği vardır. Dağılım mekânı olan bu açıklıktan doğu ve batı duvarlarındaki sivri kemerli birer açıklıkla hanın diğer bölümlerine geçilir. Giriş açıklığının sağında ve solunda, her biri giriş açıklığ1 büyüklüğünde birbirine bitişik dörder mekân bulunur. Destek kemerleri ile birbirinden ayrılmış olan bu bölümler sivri kemerli tonozlarla örtülmüştür (Demiralp, 1994, s. 55-56). 
Hazine mülkiyetindeki Rodar Hanı'nın, Akseki Belediyesi’nin talebi doğrultusunda Antalya Kültür Varlıklarını Koruma Kurulu tarafından kültürel faaliyetlerde kullanılması kararı ile Akseki Belediyesine tahsis edilmiştir.

\subsubsection{Gündoğmuș-Gelesandra-Dereyol Güzergâhı}

Antalya'ya 182 km uzaklıkta olan Gündoğmuş ilçesi, Batı Toros Dağlarının, Geyik Dağ1 eteklerine kurulmuş eski bir yerleşim merkezidir. Alanya’nın kuzeybatısında yer alır. Kuzey doğuda Konya, batıda Manavgat, güneyde Alanya ve kuzey batıda Akseki ile sınırı vardır. Yöre son derece engebelidir. Denizden yüksekliği 900 m dolayındadır. Alara çayı doğu-batı yönünde ilçeyi ikiye böler. İlçeyi yaylalar üzerinden Konya ili Hadim ve Bozkır ilçelerine bağlayan bir yol bulunmakla birlikte, kış aylarında bu yolun kapandığı ifade edilmektedir. Selçuklular, hatta Roma döneminde de bu yolun kullanıldığı anlaşılmaktadır. Selçuklular bu yol üzerinde Gündoğmuş sınırları içinde kalan iki adet kervansaray inşa etmişlerdir.

\subsubsection{Gelesandra Hanı}

Gelesandra Hanı, Gündoğmuş ilçesine 15 km mesafede Gelesandra yaylasında bulunur. Burada Selçukluların inşa ettiği bir hanın yanı sıra Roma dönemi ait bazı kalıntılar da bulunmaktadir.

Alanya'dan başlayan ipek yolunun bir kolu, Şarapsa hanına gelince ikiye ayrılır. Bunlardan birisi Güzelbağ, Kemerköprü, Narağac1, Penbelik, Gelesandra, Boğaz Han ve Baş Han yolunu izler. Diğer kol ise Aydolin(Saburlar)'dan sonra Senir'e çıkar, buradan Bozkır ve Konya'ya ulaşırdı. Antalya ve Alaiye limanlarına gelen mallar Konya’ya ulaşmak için Gündoğmuş güzergâhını takip ederdi (Özkan. 2012, s. 292-293). Çekül Vakfi'nın İpek Yolu Kültür Yolu Haritası'nda adı zikredilmemiş ve yeri işaretlenmemiştir.

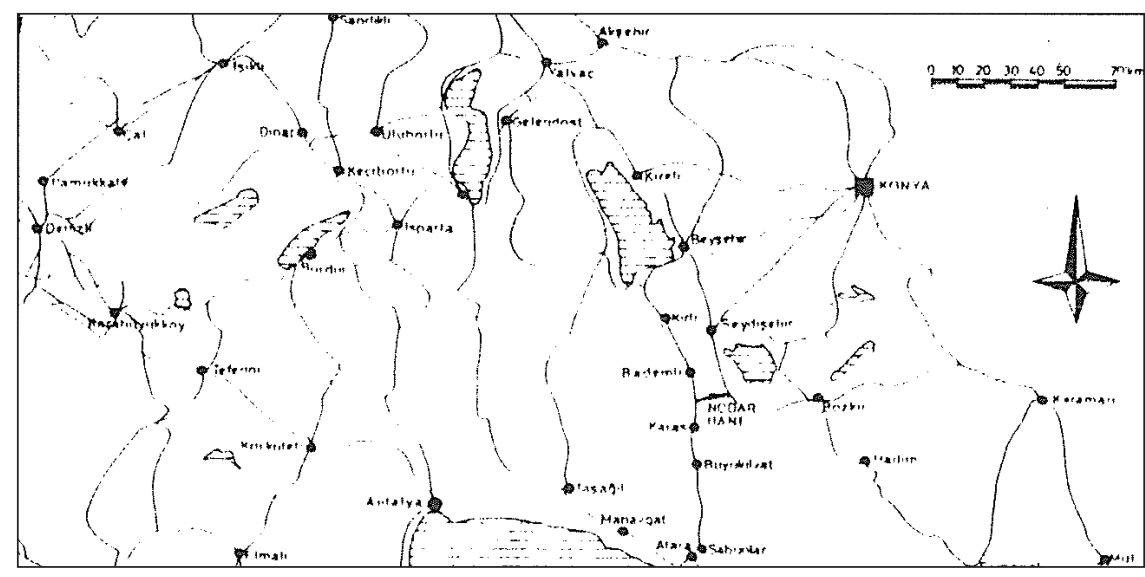

Harita 4:Antalya çevresindeki kervan yolları (Usha M. Luther'den Yekta Demirel) 


\subsubsection{Dereyol Hanı}

Dereyol Hanı, Gündoğmuş ilçesine bağlı Ortaköy beldesinin Oğuz yaylasına 3 km mesafede bulunur. Selçuklular tarafından inşa edilmiştir (Özkan. 2012, s. 293). Gelesandra Hanı ile aynı güzergâh üzerinde bulunmaktadır.

Oğuz yaylasına, Alanya - Çenger - Çavuşköy - Namaras(Çamlıtepe) - Gündoğmuş-Gelesandra - Kurucaova - Kızıloluk hattı üzerinden gidilebilir. Bu hat Alanya'ya 130 km uzaklıktadır. Dönüşte Ortaköy - Narağacı - Çayırözü - Gündoğmuş - Namaras - Cavuşköy -Alanya hattı kullanılabilir. Bu ha da $114 \mathrm{~km}$ civarındadır.

Çekül Vakfi'nın İpek Yolu Kültür Yolu Haritası'nda ismi belirtilmemiş ve yeri işaretlenmemiştir.

\section{SONUÇ}

Ticaret aslı itibariyle ekonomik bir olay olmakla birlikte sebep ve sonuçları bakımından aynı zamanda siyasi ve sosyal bir olgudur. Selçuklular ticaretin önemini çok iyi kavradıkları için ticari önem arz eden şehir ve limanları kısa zamanda fethetmişler, özellikle Antalya ve Alanya'nın fethi ile Akdeniz ticaretini kontrol altına alıp bundan yeterince istifade etmeye çalışmışlardır. Toplumun ekonomik ve sosyal düzeyini yükseltmek için Selçuklular ekonomi siyasetinde, ihracattan çok ithalata önem vermişler, başka ülkelerle yaptıkları ticari antlaşmalarını buna yönelik olarak yapmışlardır. O sıralarda Avrupa ticaretine bir konak vazifesi gören Kıbrıs, Misır ve Venedik'ten gelen mallar Antalya ve Alanya limanlarına iner, buradan çeşitli kervan yollarıyla başka Anadolu Selçuklularının başkenti olan Konya'ya ve diğer Anadolu şehirlerine ulaşırdı. Anadolu'da üretilmiş olan bazı mallar da aynı şekilde bu limanlardan ihrac edilirdi.

Ticari malların ithalat ve ihracatının yanı sıra bunların güven içinde hükümet merkezine ve diğer şehirlere ulaşması gerekiyordu. İşte bunun için çeşitli kervan yollarının açılması ve bu yollarda büyük kervansarayların inşa edilmesi lazımdı. Kervan yollarında inşa edilen kervansarayların çoğu 1215-1246 yılları arasında inşa edilmiştir. Ortalama 25 yıllık süre içinde bütün büyük hanların inşasının tamamlandığını görüyoruz ki bu büyük bir başarıdır.

Antalya'da inşa edilen kervansarayları bulundukları yok güzergâhı bakımından dört bölüme ayırmak mümkündür.

Birincisi, Antalya - Burdur güzergâhı: Bu hat üzerinde Evdir, Kırkgöz, Kırgız, Tibük, Susuz, İncir ve Ağlasun hanları bulunmaktadır.

İkincisi, Antalya - Korkuteli - Denizli güzergâhı: Bu hat üzerinde Evdir, Güllik, Küçük Yenice - Bazar - Korkuteli - Tahtalı Beli hanları bulunmaktadır.

Üçüncüsü, Antalya - Anamur güzergâhı: Bu hat üzerinde Köprüsuyu - (Birinci) Pazarcık Alara - Şarapsa - Kızlar - (İkinci) Pazarcık - Altı Kapı - Alaattin hanları bulunmaktadır.

Dördüncüsü, Manavgat - Kubadabad güzergâh1: Bu hat üzerinde Karg1 - Burma - Ebu'l-Hasan hanları bulunmaktadır. 
Beşincisi, Manavgat - Eynif - Beyşehir güzergâhı: Bu hat üzerinde Sırtköy (Murtbeli) - Eynif Tol - Ortapayam - Derebucak Tol - Çiftlik - Yeniceköy hanları bulunmaktadır.

Altıncıs1, Karg1 - Beldibi - Eynif - Beyşehir güzergâhı: Bu hat üzerinde Köprüsuyu - Karg1 -Eynif Tol - Ortapayam - Derebucak Tol hanları bulunmaktadır.

Yedincisi, Eynif - Rodar güzergâhı: Bu hat üzerinde Eynif Tol - Koca Oluk (Tolga) - Rodar hanları bulunmaktadır. Bozkır- Akören veya Seydişehir yoluyla Konya’ya ulaşılır.

Sekizincisi, Şarapsa - Gündoğmuş - Gelesandra güzergâhı: Şarapsa Han'ından sonra Gündoğmuş - Gelesandra - Dereyol - Boğaz Han ve Başhan'dan geçilerek Konya'ya ulaşılır.

Çekül Vakfı, 2012 yılında hazırladığı “İpek Yolu Kültür Yolu” haritasında Anadolu’ da şehirler arasında yer alan bütün hanlara yer verilmeye çalışılmıştır. Biz bu çalışmamızda Anadolu Selçukluları döneminde yapılmış olup günümüzde Antalya sınırları içinde kalan on bir adet kervansarayın bu haritada yer almadığını tespit ettik. Bunlar Kırgız, Tibuk, Güllik, Küçük Yenice, Bazar, Korkuteli, Tahtalı Beli, Gelesandra, Dereyol ve Koca Oluk (Tolga) hanlarıdır. Antalya il sınırları içindeki hanları bunların da isimlerinin eklenmesi gerekir.

Aynı bölgedeki hanlar bazen farklı isimlerle anıldığ ayrı ismin aynı hana ait olabileceğini vurguladık. Bazen de duruma fark edemeyip bunları iki ayrı han şeklinde değerlendirmiş olabiliriz. Bazı hanları yerinde gidip görmüş olsak bile bütün hanları görme imkanına sahip olamadık. Ulaşabildiğimiz kaynaklar bizi burada yaptığımız değerlendirmelere sevk etmiştir.

Çalışmamızda adı geçen bazı kervansaraylardan bazılarının restorasyonu tamamlanmış, bazılarına ise hiç el atılmamıştır. Tarihi ve kültürel değeri çok büyük olan hanların tamamının restore edilip bir an önce tarih ve kültür turizminin hizmetine sokulması gerekir. Konuya daha geniş perspektiften ele aldığımızda Antalya'da bir "Selçuklu Medeniyeti Müzesi” ile bir "İpek Yolu Müzesi”nin kurulması elzem görünmektedir.

\section{KAYNAKÇA}

http://www.skalantalya.org.tr/tr/antalya-hakkinda/

Akalın (Eryavuz), Ş. (2002). “Kervansaray”. Türkiye Diyanet Vakfi İslâm Ansiklopedisi. İstanbul: Türkiye Diyanet Vakfi Yay., 25, 299-302.

Akseki Belediyesi. (ts). Erişim adresi: http://www.akseki.bel.tr/index.php/bimer/26-akseki/134mahallelerimiz (12.6. 2019)

Alanya Belediyesi. Şarapsa Han. (ts). Erişim adresi: https://www.alanya.bel.tr/S/531/Sarapsa-Han (12.06.2019).

Alara Han. (ts). Erişim adresi: https://www.semerkanddanbosnaya.com/portfolio/alara-han/ (12.06.2019).

Altı kapı han. (ts). Erişim adresi: http://www.antalya-info.com/tr/Altikapi_Han.html (13.06.2019).

Antalya Belediyesi. (ts). Erişim adresi: http://antalya.bel.tr/Content/UserFiles/Files/kultur_sanat/ cekul_ipekyolu_harita_.pdf (20.07.2019).

Antalya Gezi Rehberi. Erişim adresi: http://www.antalyagezirehberi.net/alara-han.html (15.06.2019). 
Antalya hakkında (ts). http://www.skalantalya.org.tr/tr/antalya-hakkinda/ (20.07. 2019).

Antalya İ1 Kültür Müdürlüğü. (ts.). https://antalya.ktb.gov.tr/TR-67535/aspendos-belkis.html (Erişim. 09.10.2019).

Altun, A. (1989). "Alara Hanı”. Türkiye Diyanet Vakfi İslâm Ansiklopedisi. İstanbul: Türkiye Diyanet Vakfi Yay., 2, 341.

Antalya İl Kültür ve Turizm Müdürlüğü. (2012). Dünden Bugüne Antalya. Antalya İl Kültür ve Turizm Müdürlüğü Yay., Antalya. 2, 285-286.

Aytaç, İ. (2002). “Selçuklu Kervansarayları”. Türkler. 7, 854-864.

Bedirhan, Y. (2018, Nisan). "Selçuklular Devrinde Türkiye’nin İktisadî Zenginliği, Bu Zenginliğin Gerilemesinin Sebep Ve Sonuçları”. Uluslararası Sosyal Araştırmalar Dergisi. 56 (11), 117-124.

Beldibi. (2019, Ocak 2). https://www.histolia.de/karawanserei/beldibi-han/beldibi-han-beschreibung. html (09.11.2019)

Bozkurt, T. ve Wimmel, R. (2016, 6-8 Mayıs). "Bozkır-Gündoğmuş Tarihi Yol Güzergâhı Üzerine İlk Tespitler”. Uluslararası Sempozyum: Geçmişten Günümüze Bozkır, Selçuk Üniversitesi Türkiyat Araştırmaları Enstitüsü, 1489-1502.

Cansız, M. (2018). "Manavgat Sirtköy Tolhan Yazıtı", Antalya Kitabı, 1, 630-639. Antalya: Antalya Büyükşehir Belediyesi.

Cimrin, H. (01.08.2016). Antalya'y1 Sarsan Kayttle Depremler. https://www.sabah.com.tr/ akdeniz/2016/08/01/antalyayi-sarsan-kayitli-depremler (Erişim: 10.10. 2019)

Demiralp, Y. (1994). “Nodar Hanı (Akseki-Bozkır)”. Sanat Taribi Dergisi, 7, 53-58.

Dilek, Y. (2016, 6-8 Mayıs). "Bozkır, Akseki Arasındaki Ekonomik ve Sosyo-Kültürel Etkileşim”. Uluslararası Sempozyum: Geçmişten Günümüze Bozkır. (6-8 Mayıs 2016). Konya: Selçuk Üniversitesi Türkiyat Araştırmaları Enstitüsü. 835-860.

Durukan, A. (1995). “Evdir Hanı”. Türkiye Diyanet Vakfi İslâm Ansiklopedisi. Türkiye İstanbul: Diyanet Vakfi Yay., 11, 516-517.

Erdmann, K. (2018, Aralık). “Alanya Yakınlarındaki Karg1 Han”. SDÜ Fen Fakültesi Sosyal Bilimler Dergisi. Çev. Mehmet Uysal ve Muhammet Güçlü. 18, 247-256.

Eravşar, O. (2017). Yolların Tanıkları Anadolu Selçuklu Hanları. Eskişehir: Konya Aydınlar Ocağı.

Erdoğdu, İ. H. (2018), Alara Han (Lisans tezi). Denizli: Pamukkale Üniversitesi, Fen-Edebiyat Fakültesi, Sanat Tarihi Bölümü.

Evdir Han. (ts). Erişim adresi: http://fotopanorama360.com/evdir-han-antalya-duzler-camidosemealti-turkey/ (15.06.2019).

Evliya Çelebi. (2005). Evliyâ Chelebi Seyahatnâmesi. Yayına haz. Yücel Dağlı- Sayet Ali Kahraman Robert Dankoff. 9. Cilt. İstanbul: Yapı Kredi Yayınları.

İbradı. (ts). https://docplayer.biz.tr/1336782-Ibradi-ibradi-dunden-bugune-antalya.html (15.06.2019).

Gezi Notlar1. (2015, 20 Mart). http://www.medicalnetwork.com.tr/2008_dosya/Gezi\%20 Notlar\%C4\%B1\%20Mart\%202015.pdf (05.11.2019).

Kayaoğlu, İ. (1981). "Anadolu Selçukluları Devrinde Ticari Hayat”. Ankara Üniversitesi İlahiyat Fakültesi Dergisi. 24, 359-373.

Kervan ve Tarihi Yollar. (2019, 1 Mays). http://www.ormanaactive.com/tr/neler-yapilir/eynif-ovasikervansaray-tol-han (15.06.2019).

Korkmaz, N. (2009). “Anadolu Selçuklu Kervansarayları”. Türkiye Mühendislik Haberleri (TMH). 453, 40-41.

Korkuteli Tarihi. (ty). http://www.antalya-info.com/tr/Korkuteli_Tarihi.html (Erişim: 10.10.2019). 
Kucur, S.S. (2009). "Selçuklular- Anadolu Selçukluları: Sosyoekonomik ve Kültürel Hayat”. Türkiye Diyanet Vakfi İslâm Ansiklopedisi. Türkiye Diyanet Vakfi Yayınları, İstanbul. 25, 384-385.

Kunduracı, O. (2017, Bahar) "Konya-Alanya Güzergâhındaki Selçuklu Kervansaraylarının Eşrefoğlu Beyliği'ne Sunduğu Katkılar”. Selçuk Üniversitesi Selçuklu Araştırmaları Dergisi. 6, 181-208.

Kültür Portalı. (ts). Erişim adresi: https://www.kulturportali.gov.tr/turkiye/antalya/gezilecekyer/alarahan-1. (12.06.2019).

Kültür ve Turizm Bakanlığı. (2019). Selçuklu kervansarayları Denizli-Doğubayazıt güzergâhı. Erişim adresi: $\quad$ https://kvmgm.ktb.gov.tr/TR-44413/selcuklu-kervansaraylari-denizli-dogubayazitguzergahi.html (15.06.2019)

Sönmez C.C. Antalya Kaleiçi Selçuklu ve Beylikler Dönemi Eserleri. (2019). Mimarlar Odası Antalya Şubesi Yayınları. Erişim adresi: file://C:/Users/Win7/Desktop/Korkuteli\%20Kervansaraylar\%C4\%B1. $\operatorname{pdf}(15.06 .2019)$.

TarihinTanıklarıHanlar(ts).Erişimadresi:https://www.kulturportali.gov.tr/portal/tarihintaniklarihanlar (17.06.2019).

Turan, O. (2019). Selçuk Kervansarayları. Erişim adresi: https://www.tarihtarih. $\mathrm{com} /$ ? Syf=26\&Syz=377157\&/Selçuk-Kervansaraylar1-/-Prof.-Dr.-Osman-Turan(17.06.2019).

Özkan, Selim Hilmi. “Tarihe Şahitlik Eden Alanya-Bozkır Yolu ve Bu Yolun Tarihi Serüveni”. Alanya XII. Tarib ve Kültür Sempozyumu. S. 292-293. Aralık 2012. Konaklı Belediyesi. 291-296.

Ünal, R. H. (2010, 1 Nisan) “Antalya-Korkuteli Kervan Yolu Üzerinde Bilinmeyen Üç Han”. Sanat Tarihi Dergisi. 19, s. 57-99.

TDK. https://kelimeler.gen.tr/tol-nedir-ne-demek-305065 (05.11.2019).

Tükel Yavuz, A. Anadolu'da Eşodaklı Selçuklu Hanları. (ts). Erişim adresi: http://jfa.arch.metu.edu.tr/ archive/0258-5316/1976/cilt02/sayi_2/187-204.pdf(17.06.2019).

Yardım, A. (2002). İstanbul'un 550. Fetih Yılı İicin Alanya Kitabeleri. İstanbul: İstanbul Fetih Cemiyeti Yayınlar1.

Yarpuzköyü.(ts).Erişimadresi:https://www.pictame.com/place/yarpuz-koyu-akseki-antalya/346117005 (17.06.2019). 